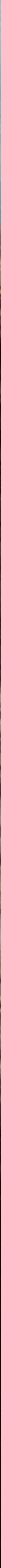


Previous page: Upper Jurassic - Lower Cretaceous sediments of the Kap Leslie and Hartz Fjeld Formations in Milne Land, East Greenland (viewed towards the east) - see Larsen et al. (2003, this volume) and Surlyk (2003, this volume). Photo: Michael Larsen. 


\title{
The Jurassic of East Greenland: a sedimentary record of thermal subsidence, onset and culmination of rifting
}

\author{
Finn Surlyk
}

The Late Palaeozoic - Mesozoic extensional basin complex of East Greenland contains a record of deposition during a period of Rhaetian - Early Bajocian thermal subsidence, the onset of rifting in the Late Bajocian, its growth during the Bathonian-Kimmeridgian, culmination of rifting in the Volgian - Early Ryazanian, and waning in the Late Ryazanian - Hauterivian. The area was centred over a palaeolatitude of about $45^{\circ} \mathrm{N}$ in the Rhaetian and drifted northwards to about $50^{\circ} \mathrm{N}$ in the Hauterivian. A major climate change from arid to humid subtropical conditions took place at the Norian-Rhaetian transition. Deposition was in addition governed by a long-term sea-level rise with highstands in the Toarcian-Aalenian, latest Callovian and Kimmeridgian, and lowstands in the latest Bajocian - earliest Bathonian, Middle Oxfordian and Volgian.

The Rhaetian - Lower Bajocian succession is considered the upper part of a megasequence, termed J1, with its base in the upper Lower Triassic, whereas the Upper Bajocian - Hauterivian succession forms a complete, syn-rift megasequence, termed J2. The southern part of the basin complex in Jameson Land contains a relatively complete Rhaetian-Ryazanian succession and underwent only minor tilting during Middle Jurassic - earliest Cretaceous rifting. Rhaetian - Lower Jurassic deposits are absent north of Jameson Land and this region was fragmented into strongly tilted fault blocks during the protracted rift event. The syn-rift successions of the two areas accordingly show different long-term trends in sedimentary facies. In the southern area, the J2 syn-rift megasequence forms a symmetrical regressive-transgressive-regressive cycle, whereas the J2 megasequence in the northern area shows an asymmetrical, stepwise deepening trend.

A total of eight tectonostratigraphic sequences are recognised in the Rhaetian-Hauterivian interval. They reflect major changes in basin configuration, drainage systems, sediment transport and distribution patterns, and in facies and depositional environments. The sequences are bounded by regional unconformities or flooding surfaces and have average durations in the order of $10 \mathrm{Ma}$. They are subdivided into conventional unconformity-bounded depositional sequences with durations ranging from tens of thousands of years, in the Milankovitch frequency band, up to several million years. Deposition was alluvial and lacustrine in the Rhaetian-Sinemurian, but almost exclusively marine during the Pliensbachian-Hauterivian time interval when a marine strait, up to $500 \mathrm{~km}$ wide and more than $2000 \mathrm{~km}$ long, developed between Greenland and Norway, connecting the Arctic Sea and the North Sea. Coal-bearing fluvial and paralic deposits occur, however, at the base of the onlapping Middle Jurassic succession in the central and northern part of the basin complex. The sedimentary development is similar to that in the Northern North Sea and on the Norwegian shelf, and East Greenland offers important onshore analogues for virtually all of the types of deeply buried Jurassic depositional systems of these areas and especially their hydrocarbon reservoirs.

Keywords: East Greenland, Jurassic, sequence stratigraphy, pre-rift megasequence, syn-rift megasequence, basin evolution, regional correlation/comparison, onshore Moray Firth

Geological Institute, University of Copenhagen, Geocenter Copenhagen, Øster Voldgade 10, DK-1350 Copenhagen K, Denmark. E-mail: finns@geo.geol.ku.dk 


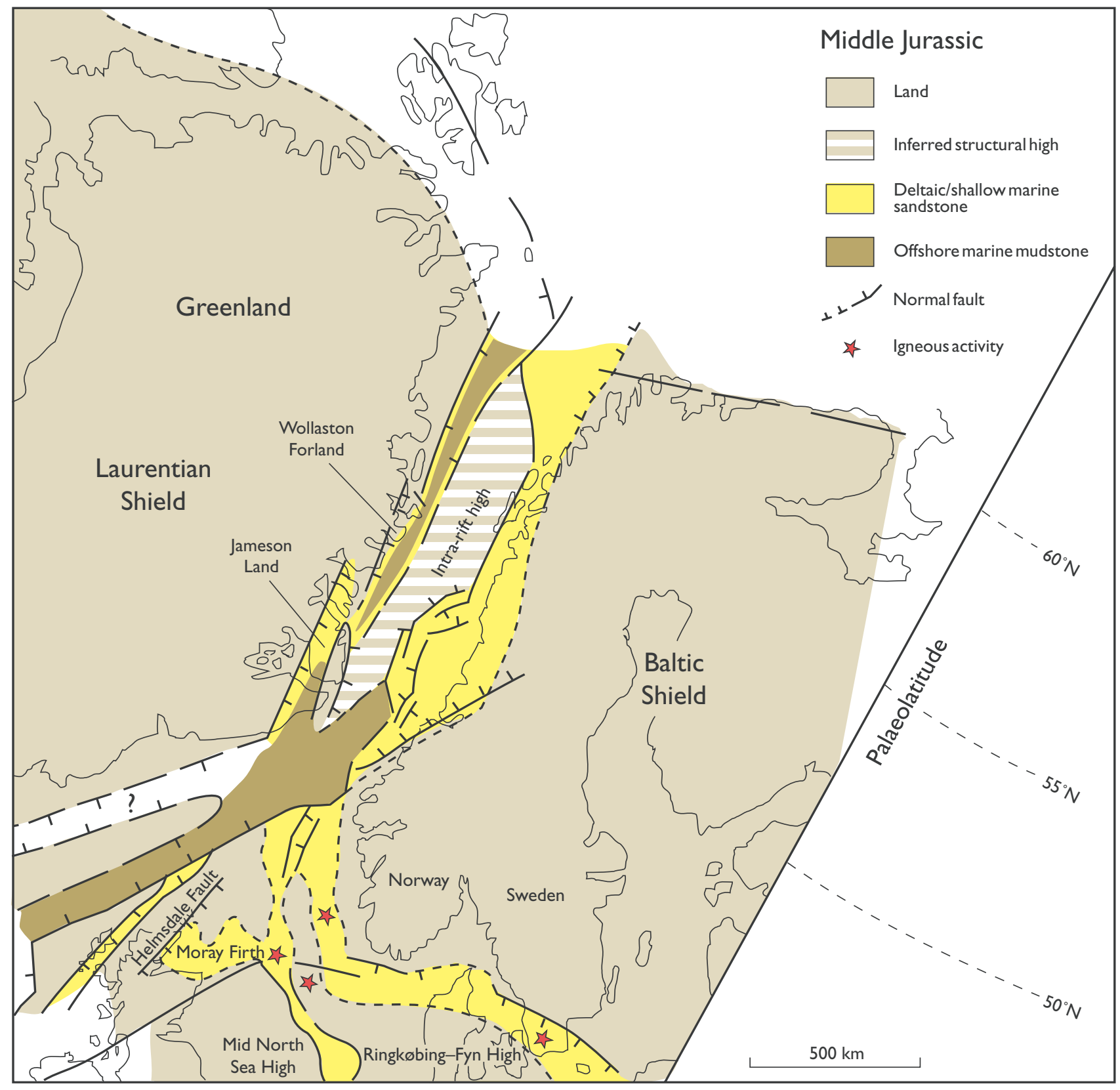

Fig. 1. Schematic pre-drift reconstruction of the seaway between Greenland and Norway showing the position of the Mesozoic rift basin of East Greenland. Based on Ziegler (1988) and Doré (1992).

The Jurassic System of East Greenland has a long history of exploration and is one of the most well-exposed ancient extensional basin successions known. In Jurassic time, an up to $500 \mathrm{~km}$ wide and more than $2000 \mathrm{~km}$ long epicontinental seaway existed between Greenland and Norway (Fig. 1; Ziegler 1988; Doré 1992). The deposits of the western margin of the seaway are today widely exposed in East Greenland through Cenozoic uplift of 1-2 km (Christiansen et al. 1992a; Hansen 2000; Johnson \& Gallagher 2000; Mathiesen et al. 2000). The deposits of the central and eastern parts of the Jurassic seaway are deeply buried in the outer shelves of offshore East Greenland and Norway, with the exception of a small outlier in Andøy in northern Norway (Dalland 1981). In East Greenland, the sub-basins form a north-south-trending belt, which is $700 \mathrm{~km}$ long, up to $175 \mathrm{~km}$ wide at the southern end and narrowing to the north where it passes into the Greenland Sea (Figs 2, 3). The extensive outcrops reveal large-scale geometries of major lithological units, and allow reconstruction of 
the main drainage patterns and sediment dispersal systems. Detailed sedimentological and sequence stratigraphic analyses can also be performed. The MiddleUpper Jurassic succession has an ammonite record that is unrivalled in the Boreal Realm, where it serves as a biochronological standard for time correlations (Callomon 1959, 1961, 1984, 1993, 1994; Surlyk et al. 1973; Sykes \& Surlyk 1976; Surlyk 1978a; Sykes \& Callomon 1979; Callomon \& Birkelund 1980, 1982; Birkelund et al. 1984; Birkelund \& Callomon 1985).

The earlier, first-generation phase of exploration coincided to a large extent with Lauge Koch's expeditions, which began in 1926 and ended in 1958. At this time, the main outline of the Jurassic succession had become known, most outcrops had been discovered and the rocks dated. These were the foundations laid through numerous expeditions led mainly by Lauge Koch over about 30 years. The main exception lay in the inland area of the large peninsula of Jameson Land, which was essentially unknown (Fig. 2). Excellent reviews of the results obtained during this phase are given by Donovan (1957) and Haller (1971).

In 1968-1971, the Jurassic of Jameson Land and Milne Land was mapped by geologists from the University of Copenhagen under the leadership of the late Tove Birkelund, and the first coherent lithostratigraphic scheme was erected (Surlyk et al. 1973). This was followed by detailed work on the Upper Jurassic lithostratigraphy, biostratigraphy, palaeoecology and palaeontology of Milne Land (Callomon \& Birkelund 1980, 1982; Fürsich 1982a, b; Birkelund et al. 1984; Birkelund \& Callomon 1985). Middle Jurassic trace fossils and facies of Jameson Land were studied by Heinberg (1970, 1973, 1974), Bromley \& Asgaard (1972) and Heinberg \& Birkelund (1984). Rhaetian - Lower Jurassic palynology was studied by Pedersen \& Lund (1980) and sedimentology by Clemmensen (1976) and Sykes (1974a, b). A Jurassic outlier in Liverpool Land was described

Fig. 2. Map of East Greenland showing the Permian-Cretaceous outcrop, major faults thought to have been active during the Jurassic and place names mentioned in the text; pre-Permian and post-Cretaceous geology not indicated. $\mathbf{A}-\mathbf{A}^{\prime}, \mathbf{B}-\mathbf{B}^{\prime}$ and $\mathbf{C}-\mathbf{C}^{\prime}$ indicate position of cross-sections on Fig. 3. Note that the term 'East Greenland' is used in a broad sense in this paper to include the entire Mesozoic rift basin extending from southernmost Jameson Land in the south to Store Koldewey in the north. This contrasts with the GEUS in-house usage in which the northern part of the basin complex, north of Kong Oscar Fjord, falls into 'North-East Greenland'. by Birkenmajer (1976). Middle-Upper Jurassic syn-rift stratigraphy and sedimentology of the successions of the northern East Greenland basin complex were studied by Clemmensen \& Surlyk (1976), Surlyk (1977a, b, 1978a, b, 1984, 1989) and Surlyk \& Clemmensen (1983). The combined results of the early exploration and mapping phase and of subsequent more focused studies were synthesised by Birkelund \& Perch-Nielsen (1976), Surlyk

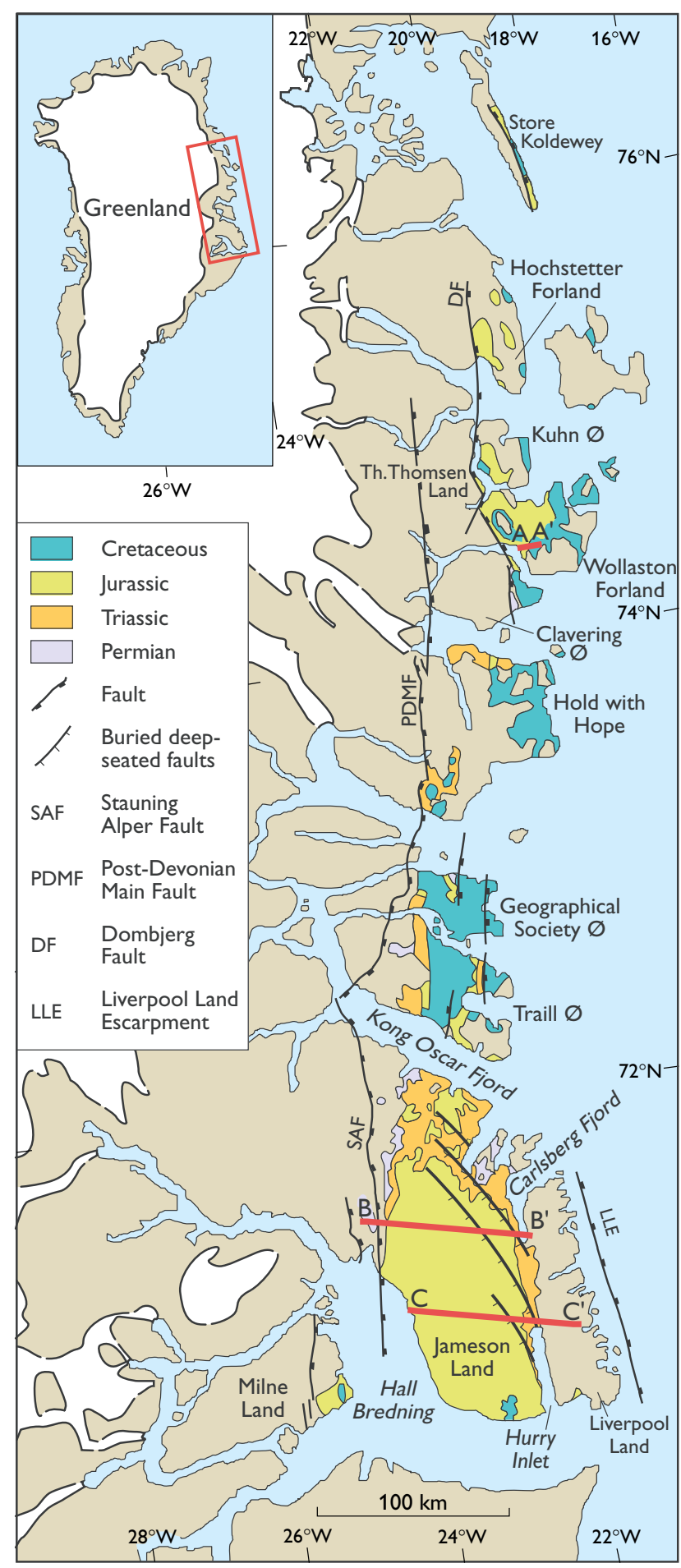




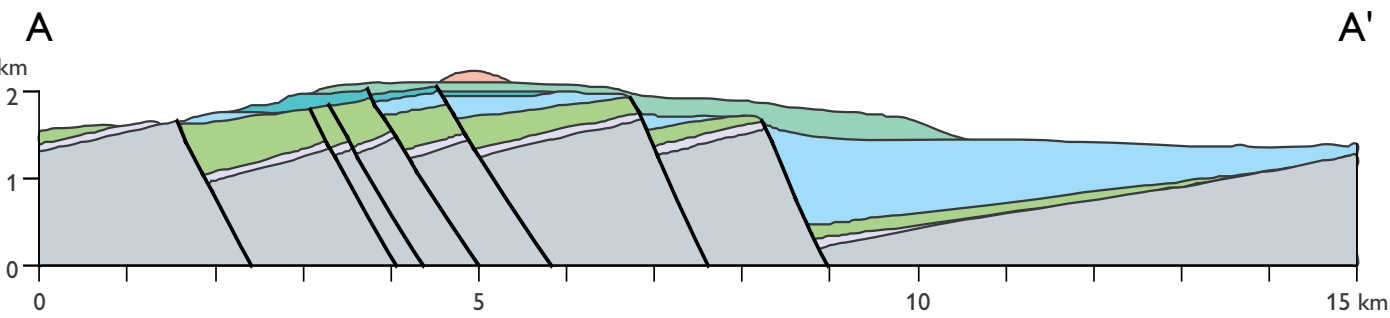

\section{Cenozoic \\ Plateau basalts}

Barremian-Albian

Hold with Hope Group

Lower Volgian - Hauterivian

Wollaston Forland Group
Upper Oxfordian - Lower Volgian

Bernbjerg Formation

Upper Bajocian (?) - Middle Oxfordian

Pelion and Jakobsstigen Formations

Upper Permian

Foldvik Creek Group

B

$\mathrm{km}$

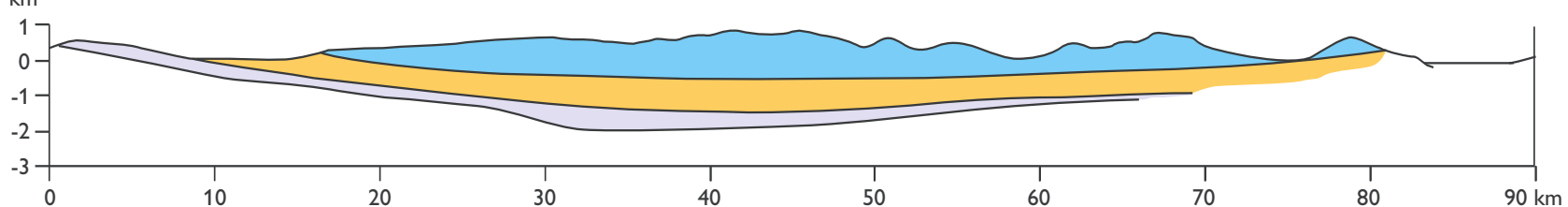

C

km

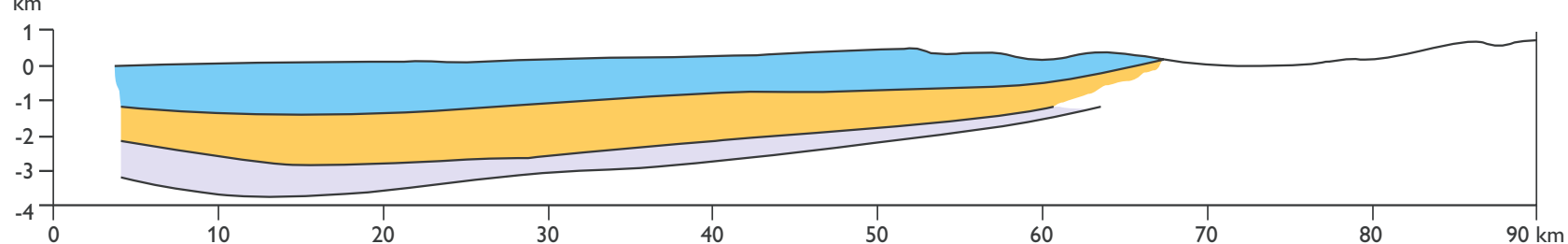

Jurassic $\square$ Triassic $\square$ Upper Permian
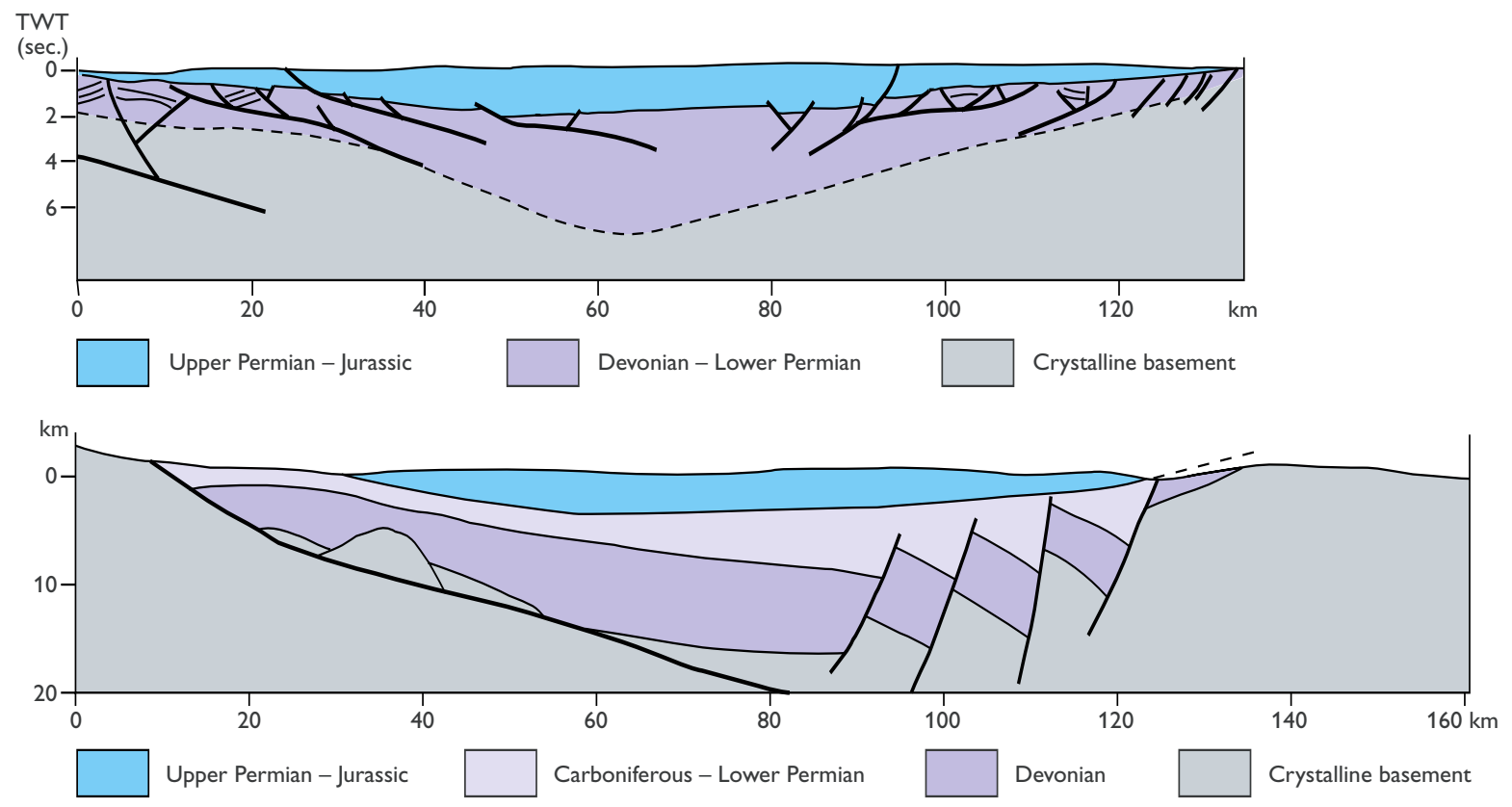
(1978a), Surlyk et al. (1981) and Surlyk (1990a), and the first low-order sequence stratigraphic interpretation of the complete Jurassic succession was presented by Surlyk (1990b, 1991a).

The most recent phase of investigation of the Jurassic of East Greenland began in the late 1980s, the main emphasis being on genetic stratigraphy and sedimentology. Much of this work was carried out by graduate students of the University of Copenhagen and form the subject of Ph.D. theses by Dam (1991), Engkilde (1994), Larsen (1995), Vosgerau (1997), Bjerrum (1999), Hansen (1999) and Therkelsen (2000). The sequence stratigraphy, sedimentology and ichnology of the uppermost Triassic - Lower Jurassic of Jameson Land were described by Dam (1990a, b), Dam \& Surlyk (1992, 1993, 1995, 1998) and Dam et al. (1995), of the Middle Jurassic of Jameson Land by Engkilde \& Surlyk (1993, 2003, this volume), of the Upper Jurassic of Milne Land by Larsen et al. (2003, this volume) and of Jameson Land by Surlyk \& Noe-Nygaard (1991, 1995, 1998, 2000a), Surlyk et al. (1993) and Larsen \& Surlyk (2003, this volume). Organic geochemistry of various shale-dominated units was presented by Dam \& Christiansen (1990), Christiansen et al. (1992b) and Krabbe et al. (1994). Detailed palynological studies were undertaken by Piasecki (1981, 1996), Milner \& Piasecki (1996), Koppelhus \& Dam (2003, this volume), Koppelhus \& Hansen (2003, this volume) and palynological data from the Lower-Middle Jurassic transition of Jameson Land were included in Underhill \& Partington (1994). Jurassic outliers in northern East Greenland were examined by Stemmerik \& Piasecki (1990), and the early rift and rift-climax deposits of the Wollaston Forland area were studied in 1995 by the author in the company of geologists from Statoil, Saga, Amoco, the Norwegian Petroleum Directorate and Aarhus University (Bojesen-Koefoed et al. 1997; Petersen et al. 1998; Vosgerau et al. 2000; Alsgaard et al.

\section{Facing page:}

Fig. 3. Upper: Schematic W-E sections of the Mesozoic basin complex of East Greenland. Note the different tectonic development of the southern and northern areas. A-A': Wollaston Forland; $\mathbf{B}-\mathbf{B}^{\prime}$ and $\mathbf{C}-\mathbf{C}^{\prime}$ : Jameson Land. Position of sections shown on Fig. 2. In Jurassic time, Jameson Land persisted as a broad, gently tilted platform, whereas deep half-grabens were formed in the Wollaston Forland area during rift culmination. Lower: W-E cross-sections showing two different interpretations of the deep structure of the Jameson Land Basin. The Mesozoic and deep structure cross-sections are based on Vischer (1943), Haller (1971), Surlyk (1991a) and Larsen \& Marcussen (1992).
2003, this volume). New outcrops and poorly known successions on Traill $\varnothing$ and Hold with Hope were described by Carr (1998), Alsen \& Surlyk (in press), Therkelsen \& Surlyk (in press), Vosgerau et al. (in press a, b). Possible palaeo-oilfields in the Traill $\varnothing-$ Geographical Society $\varnothing$ area were found and first described by Marcussen et al. (1987) and Christiansen (1994); they were investigated in more detail by Price \& Whitham (1997) and Therkelsen (2000).

The present synthesis builds on earlier reviews and studies by Donovan (1957), Haller (1971), Surlyk et al. (1981) and Surlyk (1990a, b, 1991a). It incorporates the results of the studies mentioned above, most of which are published in more detail elsewhere in this volume, and further unpublished data of the author and N. Noe-Nygaard.

A marked change from Triassic arid continental redbeds to humid drab, dark grey deposits took place in the Rhaetian and lasted throughout the Jurassic. The succession covered here thus includes the main, upper part of a Rhaetian - Lower Bajocian pre-rift megasequence, and an Upper Bajocian - Hauterivian syn-rift megasequence. A revised lithostratigraphic framework for the Jurassic of East Greenland is, at the time of printing, in the final stages of preparation by the author and co-workers. The revised and new lithostratigraphic terms shown on Figures 4 and 5 and utilised here and in other papers in this book must thus be considered as provisional, pending the publication of the lithostratigraphic revision.

Separate standard stage names are used for the Tethyan and Boreal Realms for the uppermost Jurassic - lowermost Cretaceous interval due to strong faunal provincialism among the time-diagnostic guide-fossils. In the Tethyan Realm, a succession of Kimmeridgian, Tithonian and Berriasian Stages are recognised, whereas the Kimmeridgian, Volgian and Ryazanian (or Boreal Berriasian of Russian workers) Stages are used in large parts of the Boreal Realm. The primary standard for the Jurassic-Cretaceous boundary is conventionally placed at the Tithonian-Berriasian boundary (Casey 1973; Birkelund et al. 1984; Zeiss 2003, this volume); this definition is followed here. The Volgian-Ryazanian boundary, which is commonly used as the JurassicCretaceous boundary in the Boreal Realm, roughly corresponds to the Lower-Upper Berriasian boundary (Zeiss 2003, this volume). Thus, when Boreal workers talk about the Jurassic-Cretaceous boundary, they commonly refer to a level in the middle of the Berriasian. A slightly smaller problem is presented by the BajocianBathonian Stages in the Middle Jurassic, where faunal provincialism among ammonites prevents precise correlation between the Boreal and other faunal realms. 
This problem is discussed further by Callomon (2003, this volume). Recent strontium isotope work by M. Engkilde (personal communication 2000) seems, however, to allow firmer correlation and to corroborate earlier tentative correlations based on ammonites (Callomon 1984, 1985).

The aims of the paper are to present a genetic stratigraphic interpretation of the Upper Rhaetian - Hauterivian succession of East Greenland, to evaluate the factors that governed basin evolution and sedimentation and to compare relative sea-level curves derived for the East Greenland basin and the North Sea.

\section{Structural and stratigraphic background}

A succession of sedimentary basins was formed along the eastern margin of the Precambrian shield area of Greenland in Late Palaeozoic - Mesozoic times. Basin development began in the Devonian soon after the culmination of the Caledonian orogeny, and Caledonian and older structural grains exerted an important control on subsequent basin evolution (Surlyk 1977a).

The tectonic styles, degree of crustal thinning, and basin evolution vary markedly from south to north (Fig. 3; Surlyk 1990a). Late Palaeozoic - Mesozoic basin evolution was governed by a system of old 'first order' faults some of which were formed by reactivation of Caledonian or older thrusts and weakness zones. New faults were formed during continued extensional movements. In the south, a very deep basin was formed in the Jameson Land area in Late Devonian - Early Permian times, recorded in up to $15 \mathrm{~km}$ of sediment (Surlyk 1991a; Larsen \& Marcussen 1992). This area then acted as a wide, coherent platform in Late Permian - Jurassic times and, for the most part, the succession shows an overall layer-cake geometry without major lateral changes in thickness. Subsidence was accommodated mainly along basin margin faults and there was no synsedimentary faulting of the platform. This is in strong contrast to the region north of Jameson Land, notably the Wollaston Forland - Kuhn $\varnothing$ area, which was fragmented into narrow tilted blocks during Middle Jurassic - earliest Cretaceous rifting (Figs 2, 3).

The northern and southern areas also differ in another important respect. In Jameson Land, successive basins are stacked one on top of the other. However, in the areas further north there is a marked eastwards shift in the location of progressively younger basins and depocentres. This trend was first pointed out in the classical but somewhat overlooked study of Vischer (1943); a similar, but mirror-image westwards younging of successive basins has recently been recognised on the Norwegian shelf (Doré et al. 1999). There is thus a marked tendency in the northern North Atlantic region for a symmetrical lateral offset of successive axes of crustal thinning towards the eventual line of Palaeogene break-up.

The East Greenland rift basin complex was centred over $45^{\circ} \mathrm{N}$ in the Rhaetian and drifted northwards to reach $50^{\circ} \mathrm{N}$ in the Hauterivian (Smith et al. 1994). A major climate change from arid to humid subtropical conditions took place at the Norian-Rhaetian transition.

The different structural style and degree of Late Palaeozoic crustal thinning along the length of the East Greenland basin exerted a strong control on Jurassic genetic stratigraphic development. The Jameson Land platform contains an aggradational Rhaetian - Lower Bajocian pre-rift package overlain by an overall regressive-transgressive-regressive Upper Bajocian Hauterivian syn-rift succession (Fig. 4, facing page 676). This pattern is in contrast to the areas further north, where Lower Jurassic deposits are absent and a series of backstepping events took place in Middle-Late Jurassic times reflecting increasing rates of extension, culminating in major block-tilting in the Middle Volgian (Surlyk 1991a). The two areas are separated by a system of curved NW-SE-trending, deep-seated cross-faults (Fig. 2; Dam et al. 1995). Relative sea-level curves for the two regions are thus roughly similar for the Middle and early Late Jurassic (Surlyk 1990b) but deviate for the remaining part of the Late Jurassic. The Jurassic sea level shows a long-term rise with highstands in the Toarcian-Aalenian, latest Callovian and Kimmeridgian and lowstands in the latest Bajocian - earliest Bathonian, Middle Oxfordian and in the southern area also in the Volgian, while the northern area shows continued rise during Late Jurassic times. Tectonic versus eustatic control on relative sea-level changes, and thus on the development of depositional sequences and sequence stratigraphic key surfaces, is a much-debated subject. East Greenland provides a good example of how longterm trends in sea level are influenced by tectonic style and intensity of rifting.

\section{Jurassic stratigraphy of East Greenland}

Sedimentary successions are commonly described within the framework of conventional lithostratigraphic schemes. Focus on lithostratigraphy by itself, however, may fail to highlight genetic relationships between rock units and hence to develop a thorough understanding 
of the factors governing basin evolution (Surlyk 1991a). A modern lithostratigraphic scheme is much more than a representation of simple mapping units. It should reflect a thorough understanding of the genetic stratigraphy including sequence stratigraphy of the basin fill. It should only be established when the basin and its fill has received detailed study. Premature designation of lithostratigraphic units following initial mapping commonly severely hampers succeeding work (see also Miall 1990, p. 402). The extensive nature of the Jurassic outcrops in East Greenland has, however, made possible the construction of lithostratigraphic schemes that to a large degree also reflect genetic relationships between units (Figs 4, 5; Surlyk et al. 1973; Dam \& Surlyk 1998). This is because the natural boundaries used in the definition of formations and members commonly coincide with sequence stratigraphic key surfaces rather than purely lithological changes.

The individual Jurassic formations in East Greenland are thus to a large extent genetic units bounded by key surfaces such as unconformities, ravinement and flooding surfaces, rather than merely by arbitrary facies boundaries such as the 'incoming of the first sandstone' or the 'first glauconitic horizon'. The key surfaces in most cases have a distinct lithological expression and can be traced laterally over large areas and are thus excellent lithostratigraphic markers. The main difference between genetic stratigraphy and simple lithostratigraphy in the present case thus lies in the choice of formation boundaries, which are mainly defined by sequence stratigraphic key surfaces. It should be stressed, however, that it is their lithological expression and not their interpreted genesis that forms the basis for the lithostratigraphic definitions.

A succession of long-term genetic sedimentary units is recognised in the Jurassic succession of East Greenland (Surlyk 1991a; Surlyk \& Noe-Nygaard 2000a). Each unit consists of related facies associations representing stacked forestepping, aggradational or backstepping units deposited under roughly similar conditions. The boundaries between the units reflect major changes in tectonic style, basin configuration, drainage patterns or overall depositional environments. The boundaries are unconformities, flooding surfaces and regional facies changes marking discrete basin-fill phases and commonly representing significant hiatuses. The packages are similar in nature to the Jurassic sequences recognised in the North Sea and labelled J0-J7 by Rattey \& Hayward (1993). They have durations between 5 and $20 \mathrm{Ma}$, averaging $10 \mathrm{Ma}$. However, they are not low-order sequences in a strict Exxon/Vail sense because they are not con- sistently unconformity-bound, but are instead genetic tectonostratigraphic units in the sense of Surlyk (1991b). They correspond roughly to the main basin-fill phases recognised in earlier syntheses of Surlyk et al. (1981) and Surlyk (1990a). The tectonostratigraphic units provide the basic framework for the descriptions that follow. They are subdivided into conventional depositional sequences (Posamentier \& Vail 1988) and are treated in more detail in studies of the individual units (Dam \& Surlyk 1998; Alsgaard et al. 2003, this volume; Engkilde \& Surlyk 2003, this volume; Koppelhus \& Dam 2003, this volume; Koppelhus \& Hansen 2003, this volume; Larsen et al. 2003, this volume; Larsen \& Surlyk 2003, this volume; Alsen \& Surlyk in press; Therkelsen \& Surlyk in press; Vosgerau et al. in press a, b).

\section{Tectonic-stratigraphic evolution during the Rhaetian-Hauterivian}

Two tectonostratigraphic megasequences, J1 and J2, are recognised in the Rhaetian-Hauterivian of East Greenland. J1 includes the Rhaetian - Lower Bajocian and $\mathrm{J} 2$, the Upper Bajocian - Hauterivian succession. The megasequences are subdivided into eight tectonostratigraphic sequences, termed J1.1-1.2 and J2.1-2.6 (Fig. 4). J1.1-1.2 and 2.1-2.6 are subdivided into depositional sequences labelled J2.6.1 for the lowest sequence in J2.6 etc. The number system deviates from that of Surlyk \& Noe-Nygaard (2000a) in the distinction between the two megasequences but the recognised units are the same. The East Greenland and North Sea successions show great similarities that are highlighted by the use of similar number systems, but there are also significant differences (Partington et al. 1993a, b; Rattey \& Hayward 1993).

Sequences J1.1 (Rhaetian-Sinemurian) and J1.2 (Pliensbachian - Lower Bajocian) were deposited during overall tectonic quiescence and regional subsidence and represent late post-rift deposition after rift phases in Late Permian - earliest Triassic and Early Triassic times. These two tectonostratigraphic sequences are restricted to Jameson Land, and Rhaetian-Aalenian deposits are not known from other parts of East Greenland (Fig. 4). They may have been removed by erosion during late Early Jurassic uplift of northern East Greenland followed by subsidence and Middle Jurassic onlap (Surlyk 1977a, 1978a). The absence of J1.1-1.2 north of Jameson Land seems, however, to be primary as indicated by the occurrence in northern Jameson Land of proximal facies of the Rhaetian-Sinemurian 


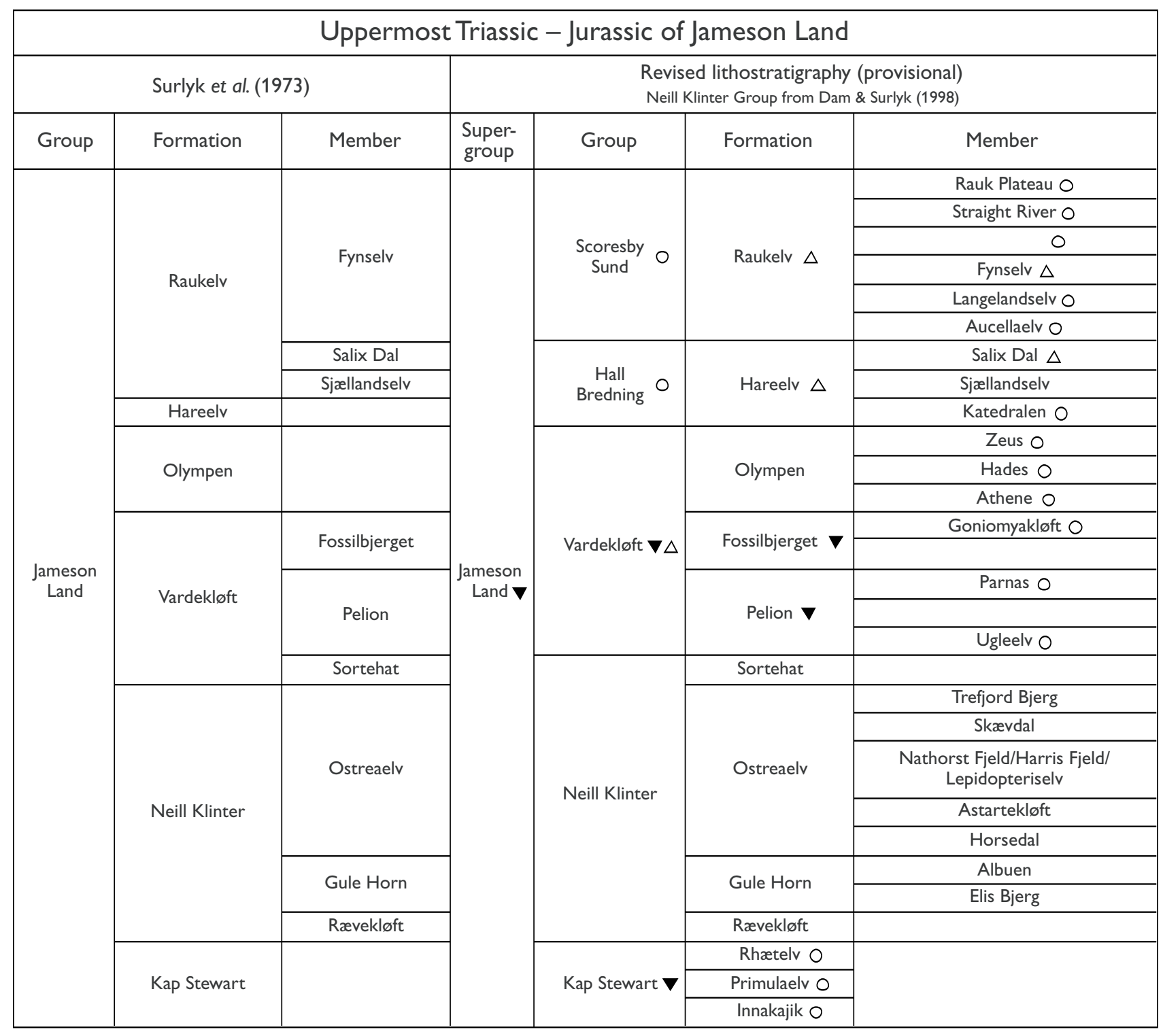

\begin{tabular}{|c|c|c|c|c|c|}
\hline \multicolumn{6}{|c|}{ Jurassic of Milne Land } \\
\hline \multicolumn{2}{|c|}{$\begin{array}{c}\text { Callomon \& Birkelund (1980) and } \\
\text { Birkelund et al. (1984) }\end{array}$} & \multicolumn{4}{|c|}{ Revised lithostratigraphy (provisional) } \\
\hline Formation & Member & $\begin{array}{l}\text { Super- } \\
\text { group }\end{array}$ & Group & Formation & Member \\
\hline Hartz Fjeld & Hennigryggen & \multirow{11}{*}{$\begin{array}{l}\text { Jameson } \\
\text { Land } \boldsymbol{\nabla}\end{array}$} & Scoresby Sund o & Hartz Fjeld & Hennigryggen \\
\hline \multirow{8}{*}{ Kap Leslie } & Astartedal & & \multirow{8}{*}{ Hall Bredning O } & \multirow{8}{*}{ Kap Leslie } & Astartedal \\
\hline & Pernaryggen & & & & Pernaryggen \\
\hline & Krebsedal & & & & Krebsedal \\
\hline & Gråkløft & & & & Gråkløft \\
\hline & Cardioceraskløft & & & & Cardioceraskløf \\
\hline & Bays Elv & & & & Bays Elv \\
\hline & Aldinger Elv & & & & Aldinger Elv \\
\hline & Kosmocerasdal & & & & Kosmocerasdal \\
\hline \multirow{2}{*}{ Charcot Bugt } & Mudderbugt & & \multirow{2}{*}{ Vardekløft $\nabla \Delta$} & \multirow{2}{*}{ Charcot Bugt } & Mudderbugt \\
\hline & Visdal & & & & Visdal \\
\hline
\end{tabular}
O New
$\triangle$ Revised
Elevated in rank 


\begin{tabular}{|c|c|c|c|c|c|c|}
\hline \multicolumn{7}{|c|}{ Jurassic of Store Koldewey and Germania Land } \\
\hline \multicolumn{3}{|c|}{$\begin{array}{c}\text { Surlyk (1977b) } \\
\text { based on Ravn (1911) } \\
\text { and Koch (1929) }\end{array}$} & \multirow[t]{2}{*}{$\begin{array}{c}\text { Stemmerik \& } \\
\text { Piasecki (1990) }\end{array}$} & \multicolumn{3}{|c|}{ Revised lithostratigraphy (provisional) } \\
\hline Group & Formation & Member & & $\begin{array}{l}\text { Super- } \\
\text { group }\end{array}$ & Group & Formation \\
\hline \multirow{3}{*}{$\begin{array}{l}\text { Jameson } \\
\text { Land }\end{array}$} & & & cf. Bernbjerg & \multirow{3}{*}{$\begin{array}{c}\text { Jameson } \\
\text { Land }\end{array}$} & Hall Bredning 0 & Bernbjerg \\
\hline & Kløft I & & \multirow{2}{*}{ Trækpas } & & \multirow{2}{*}{ Vardekløft $\mathbf{\nabla} \Delta$} & Payer Dal \\
\hline & Vardekløft & Pelion & & & & Pelion $\boldsymbol{\nabla}$ \\
\hline
\end{tabular}

\begin{tabular}{|c|c|c|c|c|c|c|}
\hline \multicolumn{7}{|c|}{$\begin{array}{l}\text { Jurassic - lowermost Cretaceous of Hold with Hope, Clavering } \varnothing \text {, } \\
\text { Wollaston Forland, Kuhn } \varnothing \text { and Hochstetter Forland }\end{array}$} \\
\hline \multicolumn{3}{|c|}{ Surlyk (1977b, 1978b) } & \multicolumn{4}{|c|}{ Revised lithostratigraphy (provisional) } \\
\hline Group & Formation & Member & $\begin{array}{l}\text { Super- } \\
\text { group }\end{array}$ & Group & Formation & Member \\
\hline \multirow{7}{*}{$\begin{array}{l}\text { Wollaston } \\
\text { Forland }\end{array}$} & \multirow{4}{*}{$\begin{array}{l}\text { Palnatokes } \\
\text { Bjerg }\end{array}$} & Rødryggen & \multirow{14}{*}{$\begin{array}{l}\text { Jameson } \\
\text { Land } \boldsymbol{\nabla}\end{array}$} & \multirow{7}{*}{$\begin{array}{l}\text { Wollaston } \\
\text { Forland }\end{array}$} & \multirow{4}{*}{$\begin{array}{l}\text { Palnatokes } \\
\text { Bjerg }\end{array}$} & Rødryggen \\
\hline & & Albrechts Bugt & & & & Albrechts Bugt \\
\hline & & Falske Bugt & & & & Falskebugt \\
\hline & & Young Sund & & & & Young Sund \\
\hline & \multirow{3}{*}{$\begin{array}{l}\text { Lindemans } \\
\text { Bugt }\end{array}$} & Niesen & & & \multirow{3}{*}{$\begin{array}{l}\text { Lindemans } \\
\text { Bugt }\end{array}$} & Niesen \\
\hline & & Rigi & & & & Rigi \\
\hline & & Laugeites Ravine & & & & Laugeites Ravine \\
\hline \multirow{6}{*}{$\begin{array}{l}\text { Jameson } \\
\text { Land }\end{array}$} & \multirow{2}{*}{ Bernbjerg } & & & \multirow{2}{*}{$\stackrel{\text { Hall }}{\text { Bredning }} \bigcirc$} & \multirow{2}{*}{ Bernbjerg } & \\
\hline & & & & & & Ugpik Ravine $\bigcirc$ \\
\hline & \multirow{4}{*}{ Vardekløft } & Jakobsstigen & & \multirow{5}{*}{ Vardekløft $\Delta$} & Jakobsstigen $\boldsymbol{\nabla}$ & \\
\hline & & & & & Payer Dal & \\
\hline & & Pellon & & & Pelion $\boldsymbol{\nabla} \Delta$ & Spath Plateau \\
\hline & & Muslingebjerg & & & Muslingebjerg $\boldsymbol{\nabla}$ & \\
\hline & & & & & Bastians Dal & \\
\hline
\end{tabular}

\begin{tabular}{|c|c|c|c|c|c|c|}
\hline \multicolumn{7}{|c|}{ Jurassic of Traill $\varnothing$ and Geographical Society $\varnothing$} \\
\hline \multicolumn{3}{|c|}{ Surlyk (1977b) } & \multicolumn{4}{|c|}{ Revised lithostratigraphy (provisional) } \\
\hline Group & Formation & Member & $\begin{array}{l}\text { Super- } \\
\text { group }\end{array}$ & Group & Formation & Member \\
\hline \multirow{6}{*}{$\begin{array}{l}\text { Jameson } \\
\text { Land }\end{array}$} & Bernbjerg & & \multirow{6}{*}{$\begin{array}{c}\text { Jameson } \\
\text { Land }\end{array}$} & Hall Bredning o & Bernbjerg & \\
\hline & \multirow{5}{*}{ Vardekløft } & & & \multirow{5}{*}{ Vardekløft $\boldsymbol{\nabla} \Delta$} & Olympen & \\
\hline & & & & & Fossilbjerget $\boldsymbol{\nabla}$ & \\
\hline & & \multirow{3}{*}{ Pelion } & & & Pelion 7 & Parnas 0 \\
\hline & & & & & & \\
\hline & & & & & Bristol Elv & \\
\hline
\end{tabular}

Fig. 5. Revised stratigraphic schemes for the Jurassic of East Greenland compared to earlier schemes of Surlyk et al. (1973), Surlyk (1977b, 1978b), Callomon \& Birkelund (1980), Birkelund et al. (1984) and Stemmerik \& Piasecki (1990). Stratigraphy of the Neill Klinter Group from Dam \& Surlyk (1998). As discussed in the text, the revised lithostratigraphy should be considered provisional, pending publication; the annotations 'new, revised, elevated in rank' refer to this comprehensive lithostratigraphic revision. 


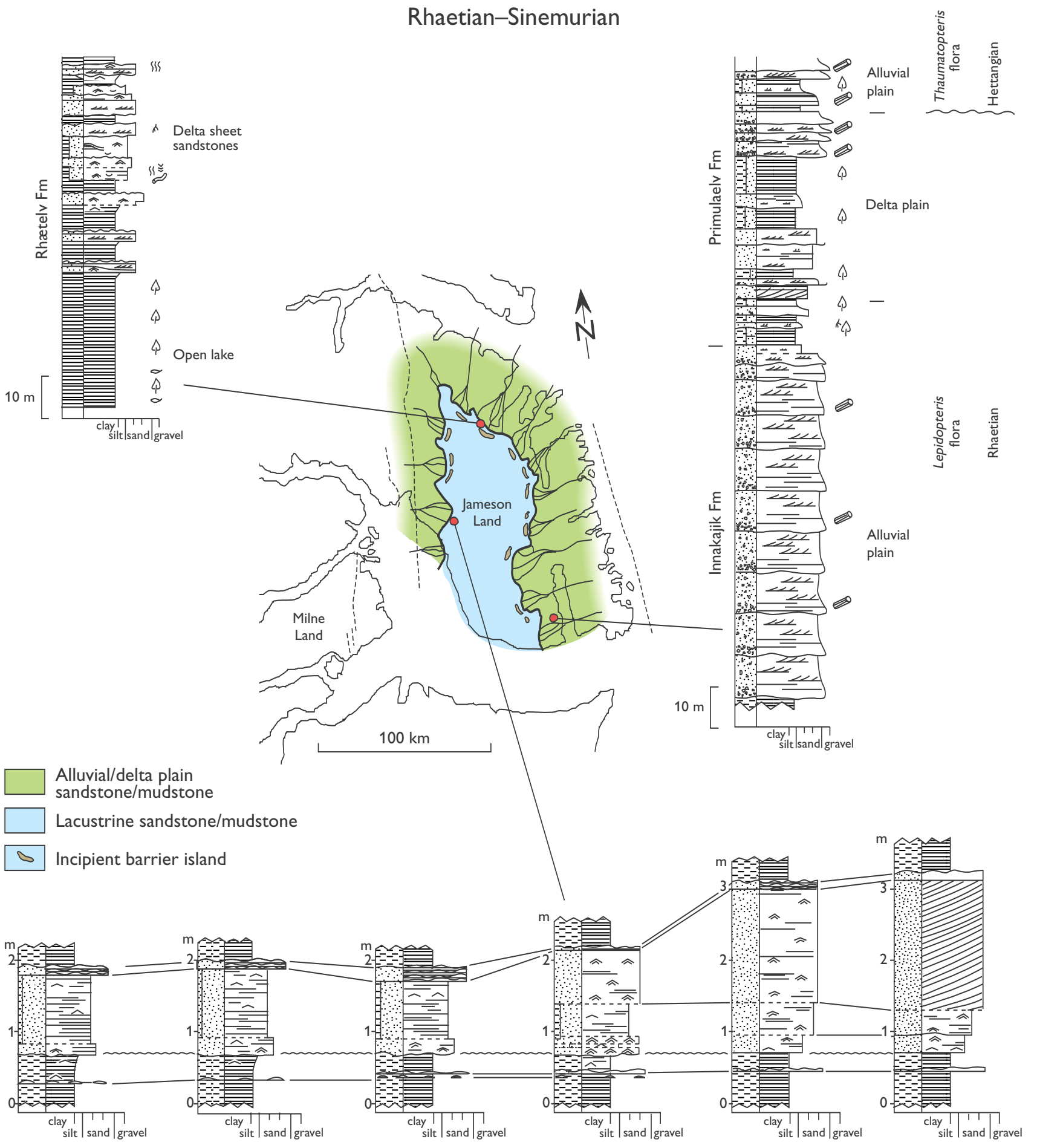

Delta sheet sandstone, strike section

Rhætelv Fm

Fig. 6. Palaeogeographic map of the Rhaetian-Sinemurian fluvio-lacustrine Kap Stewart Group. Characteristic sections through lacustrine, deltaic and alluvial plain deposits shown. Based on Dam \& Surlyk (1993). The accompanying legend is also applicable to Figs 9, 10, 12, 13, 16-18, 25-29, 32, 36 and 37. 


\section{Sedimentary logs}

Coal

Claystone

E=-二=-7 Mudstone

Sandstone

Muddy sandstone

. Pebbly sandstone

$\therefore$ Siderised rip-up mudstone

clasts/conglomerate

然: Conglomerate, sandstone matrix

$\bigodot_{0}$ Concretion

- Mudstone clasts

..... Carbonaceous material

Pyritic mudstone

\section{Bed contacts}

$\sim$ Sharp/erosional or irregular

Sharp planar

- - Gradational

\section{Sedimentary structures}

Parallel lamination

DIIIJ Planar cross-bedding

Trough cross-bedding

Cross-bedding with pebbles

along foresets

I Structureless

\$) Slumping

Heterolithic sediments

Rhythmic lamination

$\triangle \triangle \equiv$ Lenticular bedding

$\cong$ Wavy bedding

7 Flaser bedding

Mud partings

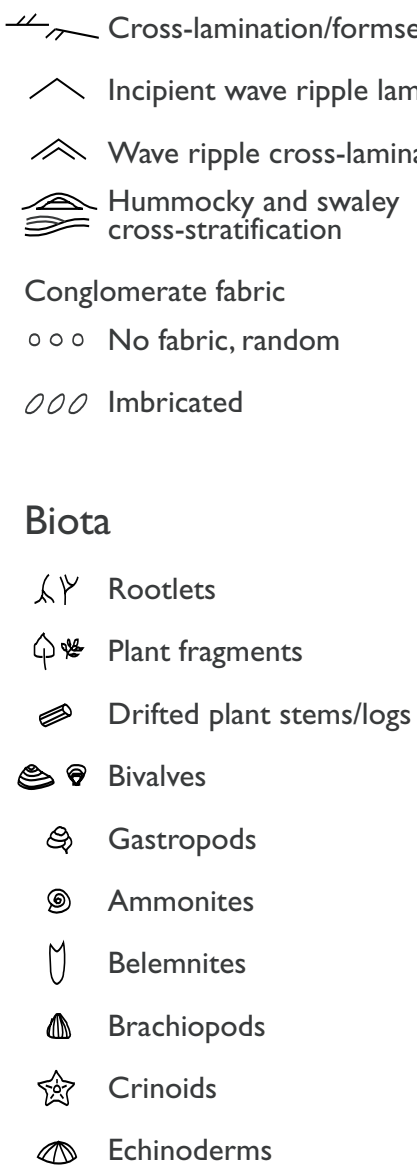

Palaeocurrents, miscellaneous

Foreset orientation (cross-

lamination, cross-bedding)

Crestline orientation of wave

+ ripples

$\searrow$ Bidirectional current indicators

Current rose

Coarsening-upwards trend

Fining-upwards trend

\section{Trace fossils}

S Weak

SS Moderate bioturbation

SSS Intense

$\checkmark$ Arenicolites isp.

y. Chondrites isp.

es) Curvolithos multiplex

U Diplocraterion habichi

Y Diplocraterion isp.

Diplocraterion parallelum

mิ Gyrochorte comosa

$m$ Gyrochorte isp.

( Helminthoida isp.

§. Helminthopsis magna

Y Monocraterion isp.

9 Monocraterion tentaculatum

\& Ophiomorpha nodosa

澡 Phoebichnus trochoides

Planolites isp.

of Skolithos isp.

6 Taenidium serpentinum

ह Teichichnus isp.

1 Thalassinoides isp.

$\approx$ Escape burrow

Unidentified sinuous

horizontal burrow 
Kap Stewart Group and the Pliensbachian - Lower Bajocian Neill Klinter Group. The reality of Early Jurassic domal uplift to the north of Jameson Land, originally suggested on stratigraphic grounds by Surlyk (1977a, 1978a), has recently been confirmed on the basis of apatite fission track thermochronology by Johnson \& Gallagher (2000). In contrast, the Jameson Land area shows no evidence for Early Jurassic uplift and cooling (Mathiesen et al. 2000).

The Upper Bajocian - Volgian of Jameson Land shows an overall regressive-transgressive-regressive development. The initial progradational phase took place in the Late Bajocian. It was followed by Late Bathonian transgression leading to maximum flooding in the Middle Callovian and the Late Kimmeridgian - earliest Volgian punctuated by progradational interludes in latest Callovian - Late Oxfordian times. Maximum Late Kimmeridgian flooding was succeeded by a major regression in the Volgian culminating at the Volgian-Ryazanian boundary, i.e. at the Lower-Upper Berriasian boundary. Deposition of J2.1 (Upper Bajocian - Middle Bathonian) reflects the onset of rifting. Block faulting with gentle tilting began, the depositional basin was extended far to the north, drainage and sediment transport patterns were fundamentally changed, and enormous volumes of sand were shed into the basin. J2.2 (Upper Bathonian - Upper Callovian) records increased rates of extension and block tilting, and progressive drowning of the sandy depositional system. J2.3 (uppermost Callovian - Middle Oxfordian) reflects minor progradational episodes, and J2.4 (Upper Oxfordian - Lower Volgian) is characterised by a basin margin progradational interlude along the western basin margin in Milne Land followed by maximum drowning. J2.5 (Middle Volgian - Upper Ryazanian) was characterised by rapid progradation, and sandy depositional systems of J2.6 (Upper Ryazanian - Hauterivian) prograded to the basin axis.

The areas further north in the Wollaston Forland region also show initial Late Bajocian(?) - Bathonian progradation, followed by stepwise Middle-Late Jurassic backstepping with flooding events in the Late Callovian, Late Oxfordian and Kimmeridgian, culminating in intensive block tilting and formation of deeply submerged half-grabens in the Middle Volgian. J2.2-2.4 are thus developed as in the Jameson Land area but increased rifting and block tilting resulted in the formation of progressively deeper water half-grabens with conglomeratic mass flow and turbidite deposition of J2.5-2.6, and the end of the Jurassic was characterised by stepwise deepening rather than progradation.

\section{J1. Rhaetian - Lower Bajocian pre-rift megasequence}

\section{Kap Stewart and Neill Klinter Groups}

The Rhaetian - Early Bajocian was a time of tectonic quiescence and regional subsidence. Sedimentation was restricted to Jameson Land, which behaved as a single coherent platform (Fig. 3). In Rhaetian time, the facies changed from continental redbeds to drab sandstones, dark mudstones and thin coals reflecting a change from an arid to a humid climate.

\section{J1.1. Rhaetian-Sinemurian: tectonic quiescence, regional subsidence, fluvial and lacustrine deposition}

\section{Kap Stewart Group}

An extensive alluvial-lacustrine complex was formed in the Late Rhaetian and persisted across the TriassicJurassic boundary into the Sinemurian (Figs 4, 6, 7; Harris 1937; Pedersen \& Lund 1980; Dam \& Christiansen 1990; Dam \& Surlyk 1992, 1993; Dam et al. 1995; McElwain et al. 1999; Hesselbo et al. 2002). The deposits are up to about $600 \mathrm{~m}$ thick (Fig. 8), and are placed in the Kap Stewart Group, which in Jameson Land conformably overlies red, marly mudstones, grey sandstones and carbonates of the fluvial and lacustrine Norian - Lower Rhaetian Ørsted Dal Member (Fleming Fjord Formation; Clemmensen 1980a, b). The boundary is unconformable along the south-eastern basin margin in southern Liverpool Land, where the Kap Stewart Group, which is here only 20 m thick, oversteps the Ørsted Dal Member and rests on the Klitdal Member (Birkenmajer 1976).

Along the basin margins, the group consists of coarsegrained alluvial plain deposits (Innakajik Formation), overlain by finer grained delta plain deposits rich in macroplant fossils (Primulaelv Formation; Figs 5, 6). The entire flora found in the Kap Stewart Group was called the Scoresby Sund flora (Harris 1937 and references therein). Gymnosperms (cycadophytes, ginkgophytes and conifers) are dominant, and ferns are also common. The Rhaetian Lepidopteris flora characterises the Innakajik Formation and the lower Primulaelv Formation; the Hettangian Thaumatopteris flora characterises the upper part of the Primulaelv Formation (Harris 1937). The two floras contain about 100 species each, and have only 5-10 species in common. A similar break occurs in the microflora (Pedersen \& Lund 


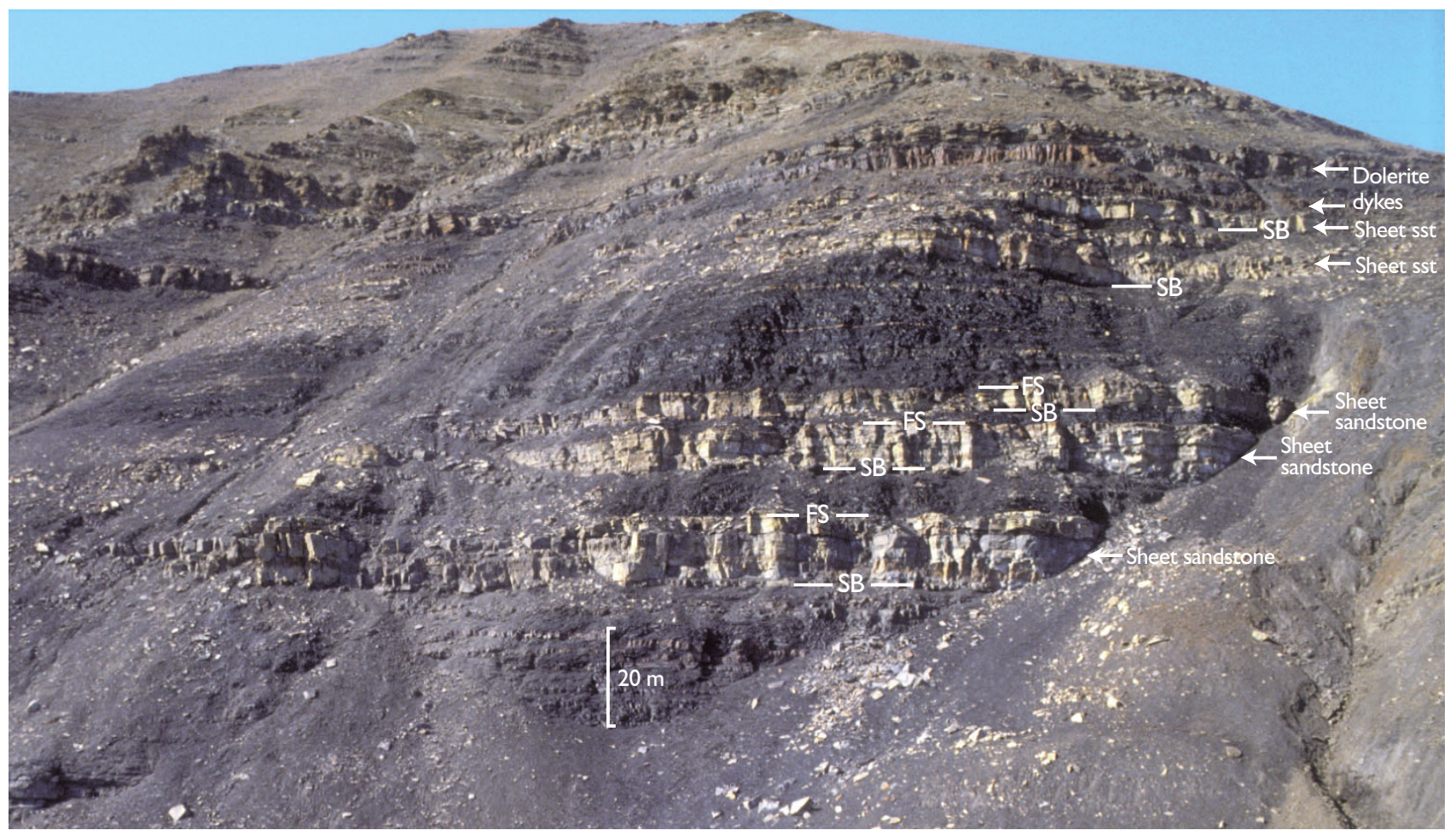

Fig. 7. Alternating deep lake black shales and shallow lake deltaic shelf sandstones of the Kap Stewart Group in Horsedal, northern Jameson Land. SB, sequence boundary; FS, flooding surface.

1980). The sharp floral break has been interpreted as reflecting species range truncations at a major hiatus (Harris 1937; Pedersen \& Lund 1980). This interpretation is probably not tenable. The two highly diverse and still remarkably different floras and the presence of a transition zone, up to about $10 \mathrm{~m}$ thick, is here interpreted to reflect a real floral turnover at or close to the Triassic-Jurassic boundary. The main facies changes occur in the lower part of the Lepidopteris flora interval and the floral break is associated with only a minor change in fluvial style (Dam \& Surlyk 1993). This could be the direct sedimentological result of a floral mass extinction. The reality of the floral turnover is corroborated by a study of stomatal changes between the two floras and the derived fourfold increase in atmospheric $p \mathrm{CO}_{2}$ suggesting a $3-4^{\circ} \mathrm{C}$ 'greenhouse' warming across the boundary (McElwain et al. 1999).

The lacustrine deposits of the basin centre consist of alternating black, laminated mudstones and sheet sandstones (Rhætelv Formation; Figs 5, 6, 7). The black

Fig. 8. Map of Jameson Land showing alignment of depocentres of the Kap Stewart Group parallel to deeply buried basement faults. Modified from Dam et al. (1995).

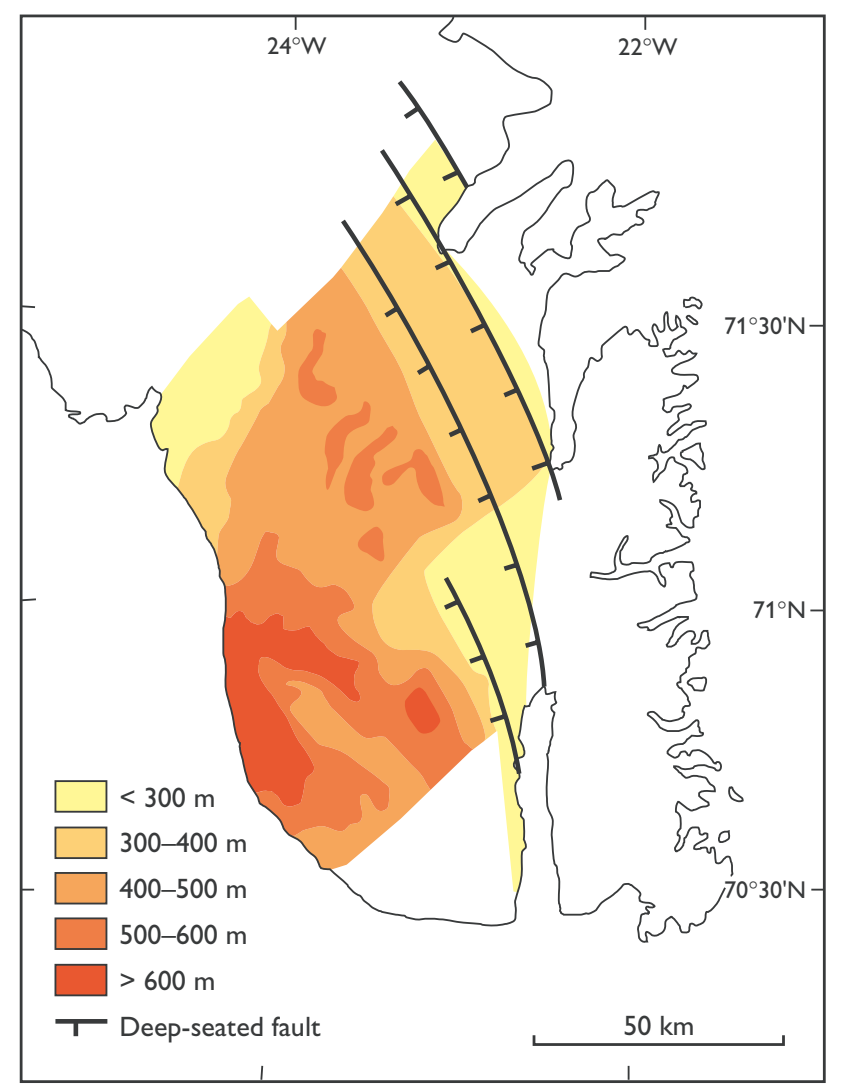


A

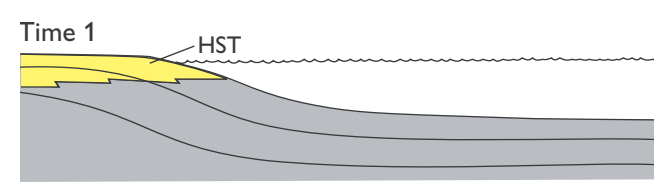

Time 2

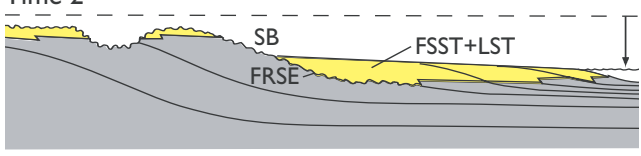

Time 3

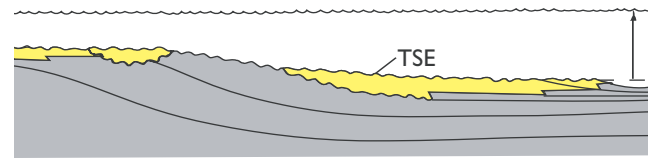

Time 4

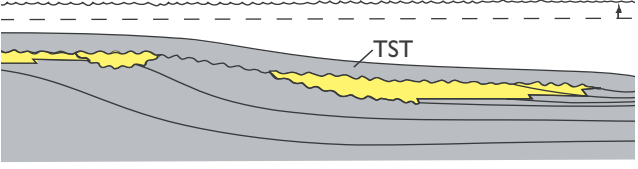

Time 5

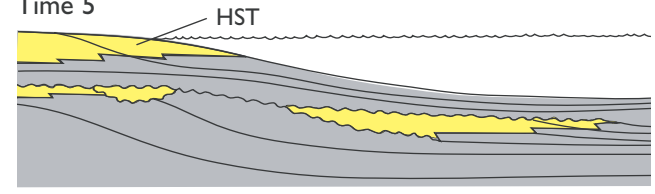

Formation of delta sheet sands during lacustrine forced regressions
B

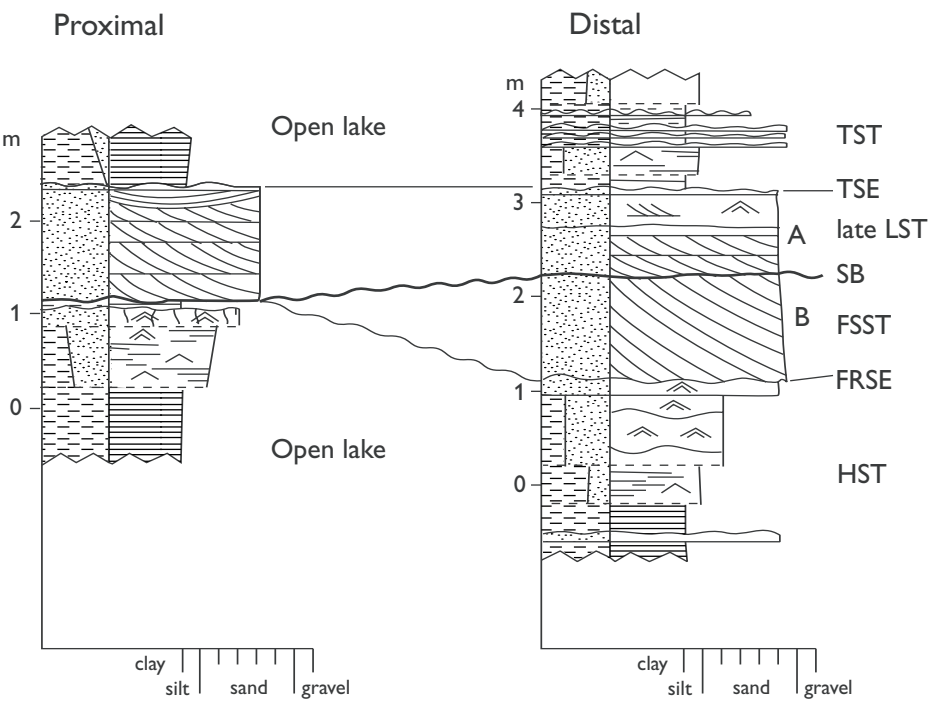

FSST Falling stage systems tract

SB Sequence boundary

LST Lowstand systems tract

TSE Transgressive surface of erosion

TST Transgressive systems tract

Fig. 9. A: Development of detached lowstand deltas formed during lake level fall and associated forced regression (based on Dam \& Surlyk 1993 and Posamentier \& Allen 1999). B: Sequence stratigraphic interpretation of deep-shallow-deep lake cycles of the Kap Stewart Group (Rhætelv Formation). Sections from Dam \& Surlyk (1993); for legend, see Fig. 6.

mudstones were deposited mainly during periods of lake-level highstand in relatively deep water under poorly oxygenated conditions. In contrast, the sheet sands were formed by delta progradation during lakelevel lowstand and associated forced regression (Fig. 9). The sharp lower boundaries of many of the sheet sandstones are lacustrine regressive surfaces of erosion and form master sequence boundaries (Posamentier \& Allen 1999) or bases of falling stage (Plint \& Nummedal 2000) or forced regressive systems tracts (Hunt \& Tucker 1992, 1995). The upper boundaries are coincident high order sequence boundaries, lacustrine flooding surfaces, and transgressive surfaces of erosion. The deep to shallow lake cycles are thus high-frequency lacustrine sequences. The cyclical alternation of the two facies types shows that the lake experienced numerous high-frequency and high-amplitude changes in water level and shifted from open to closed conditions (Dam \& Surlyk 1992, 1993). About 50 deep lake mudstone - shallow delta sandstone cycles have been recognised. The age con- trol is, however, poor and the duration of the cycles cannot yet be estimated, but it is believed that the cyclicity could be of Milankovitch type and be climatically controlled. It is noteworthy that the cycles of the lacustrine Kap Stewart succession are coeval with the wet-dry cycles of the upper part of the Newark Supergroup in eastern North America where Milankovitch-controlled cyclicity is well-documented (Olsen et al. 1996).

\section{J1.2. Pliensbachian - Early Bajocian: continued regional subsidence, marine, tidal embayment and restricted offshore deposition}

\section{Neill Klinter Group}

The Kap Stewart lake came to an end at the SinemurianPliensbachian transition when the Jameson Land area underwent marine transgression (Figs 10, 11; Dam \& Surlyk 1998). Deposition seems to have continued unin- 


\section{Early Pliensbachian}

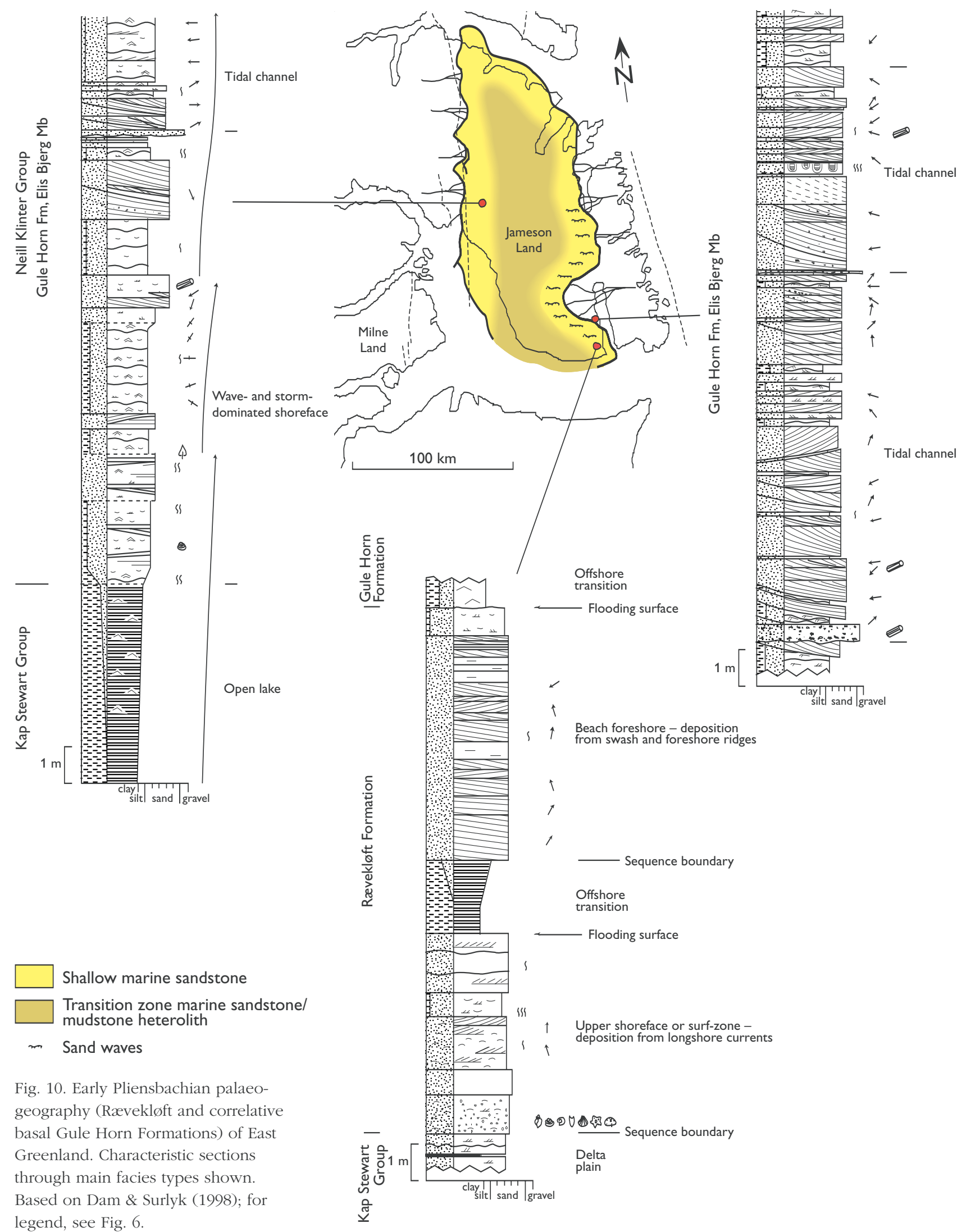




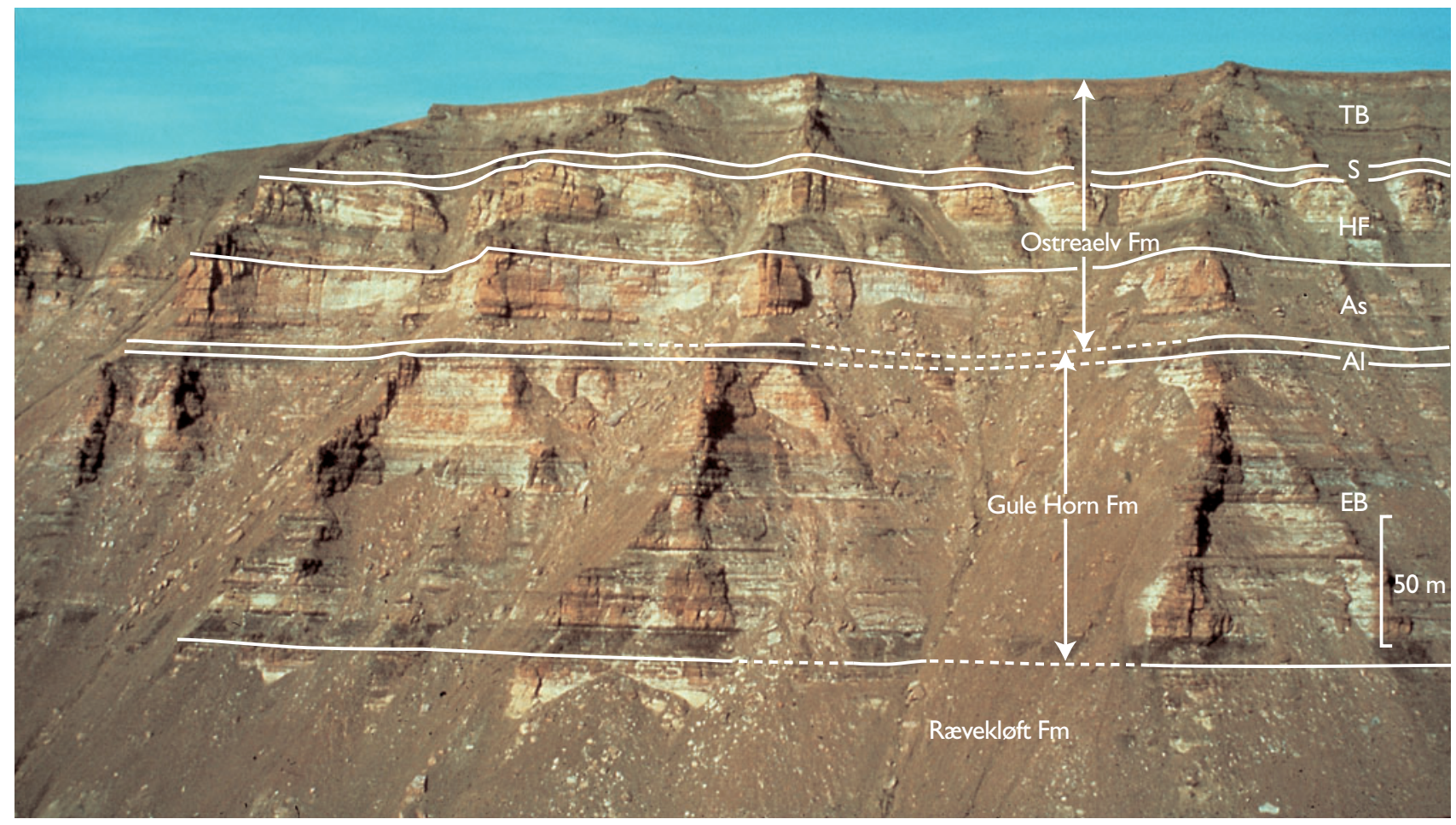

Fig. 11. The Neill Klinter Group at Harris Fjeld, south-eastern Jameson Land. Note alternating shallow marine, sandstone-dominated, and deeper marine, mudstone-dominated sheets representing individual members of the Gule Horn and Ostreaelv Formations (Pliensbachian-Toarcian). As, Astartekløft Mb; Al, Albuen Mb; EB, Elis Bjerg Mb; HF, Harris Fjeld Mb; S, Skævdal Mb; TB, Trefjord Bjerg Mb.

terrupted in the central part of the basin and the flooding is marked by a coarsening-upwards trend from lacustrine shales to fine-grained sandstones with marine body- and trace-fossils. Pliensbachian marine flooding is recorded throughout the northern North Atlantic seaway and coincides with a transgressive peak during the long-term Late Triassic - Early Jurassic sea-level rise (Hallam 1988; Haq et al. 1988; Surlyk 1990b).

The gradualness of the facies transition suggests that the lacustrine basin was low-lying and separated from the sea only by shallow barriers. A major hiatus comprising all of the Sinemurian Stage occurs, however, along the south-eastern basin margin caused by erosion and non-deposition during a period of relative sea-level fall close to the Sinemurian-Pliensbachian boundary. This may reflect a combination of a major eustatic fall and relative uplift and tilting of the Liverpool Land block to the east as shown by the alignment of depocentres along NW-SE-trending border faults at the northeastern end of the Jameson Land platform. The basin had the same extent as during Kap Stewart time and was bounded by land to the west, north and east with a marine connection to the south (Figs 6, 10).
In the basin centre, the marine Pliensbachian succession comprises stacked parasequences of wave- and storm-dominated offshore transition zone and shoreface tidal channel deposits (Elis Bjerg Member, Gule Horn Formation; Fig. 4). Along the south-eastern margin, the succession consists of coarse-grained foreshore and shoreface deposits (U. jamesoni - P. davoei Chronozones, Rævekløft Formation), which may be separated by offshore transition zone mudstones representing flooding in the I. ibex Chron.

Early Pliensbachian source areas were located along western, northern and eastern basin margins. Sediment was distributed by tidal currents in wide dune fields, which passed basinwards into restricted wave- and storm-dominated shelf environments.

A major landwards shift in facies occurred in the Late Pliensbachian and a wedge of storm-dominated lower shoreface sediments associated with muddy debrite conglomerates were deposited along the south-eastern basin margin (Albuen Member, Gule Horn Formation; Figs 11, 12). This may reflect a sea-level rise accompanied by erosion of shoreline cliffs. The transgressive development came to an end in the latest Pliensbachian, marked by an important basinwards shift in facies rep- 


\section{Late Pliensbachian}
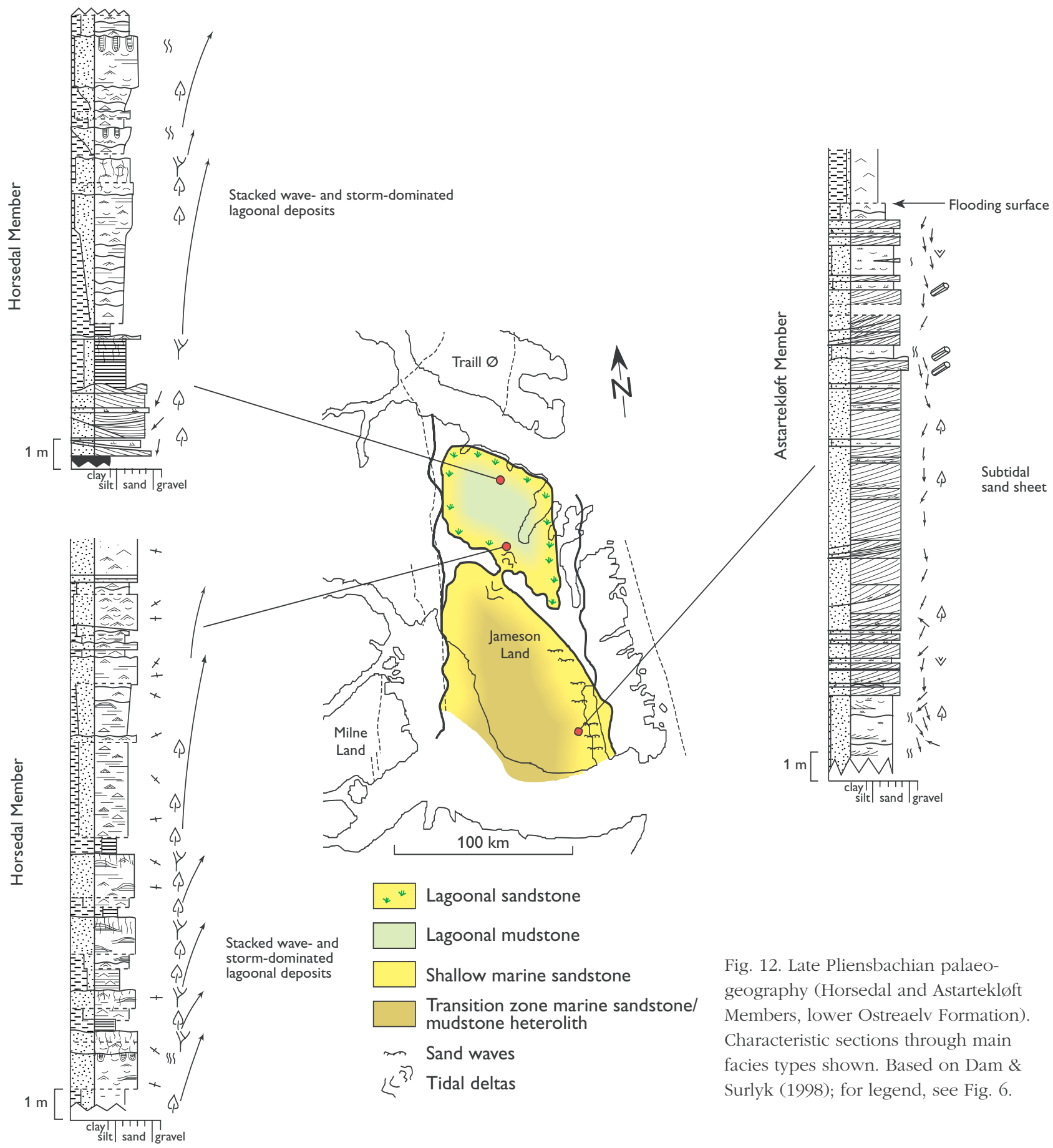

Fig. 12. Late Pliensbachian palaeogeography (Horsedal and Astartekløft Members, lower Ostreaelv Formation) Characteristic sections through main facies types shown. Based on Dam \& Surlyk (1998); for legend, see Fig. 6.

resented by subtidal channel and subtidal sand sheet deposits (Astartekløft Member).

A remarkable lateral facies change took place in the northern part of the basin where stacked lagoonal parasequences capped by rootlet beds were formed (Horsedal Member, Gule Horn Formation; Fig. 4). The lagoonal deposits covered more than $3000-4000 \mathrm{~km}^{2}$ (Fig. 12). Seismic data suggest that the position of the barrier protecting the lagoon was controlled by deepseated NW-trending basement faults and the barrier was apparently located over the subtle footwall crest of the main fault (Figs 2, 8; Dam et al. 1995). 


\section{Early Toarcian}
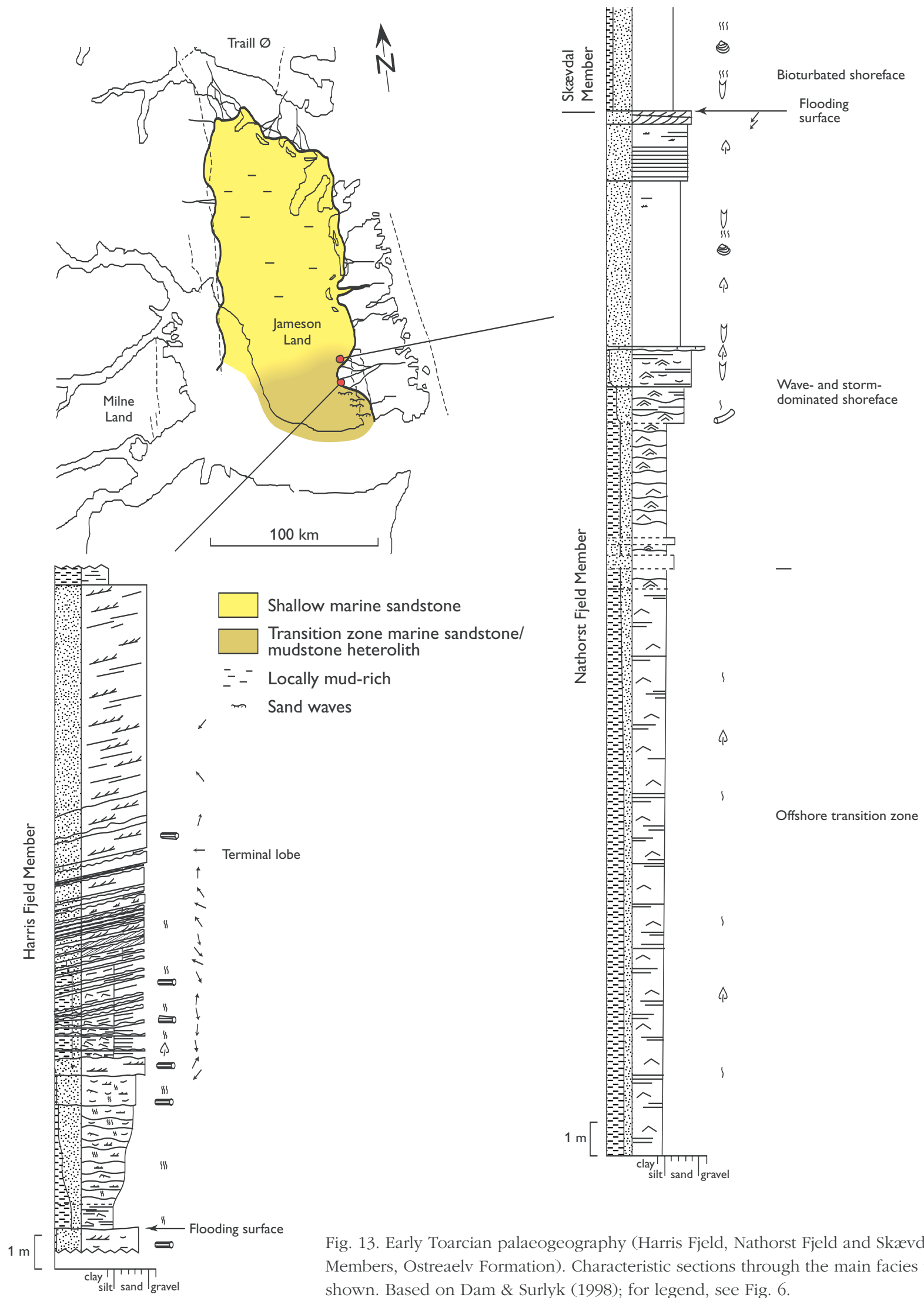

Fig. 13. Early Toarcian palaeogeography (Harris Fjeld, Nathorst Fjeld and Skævdal Members, Ostreaelv Formation). Characteristic sections through the main facies types shown. Based on Dam \& Surlyk (1998); for legend, see Fig. 6. 


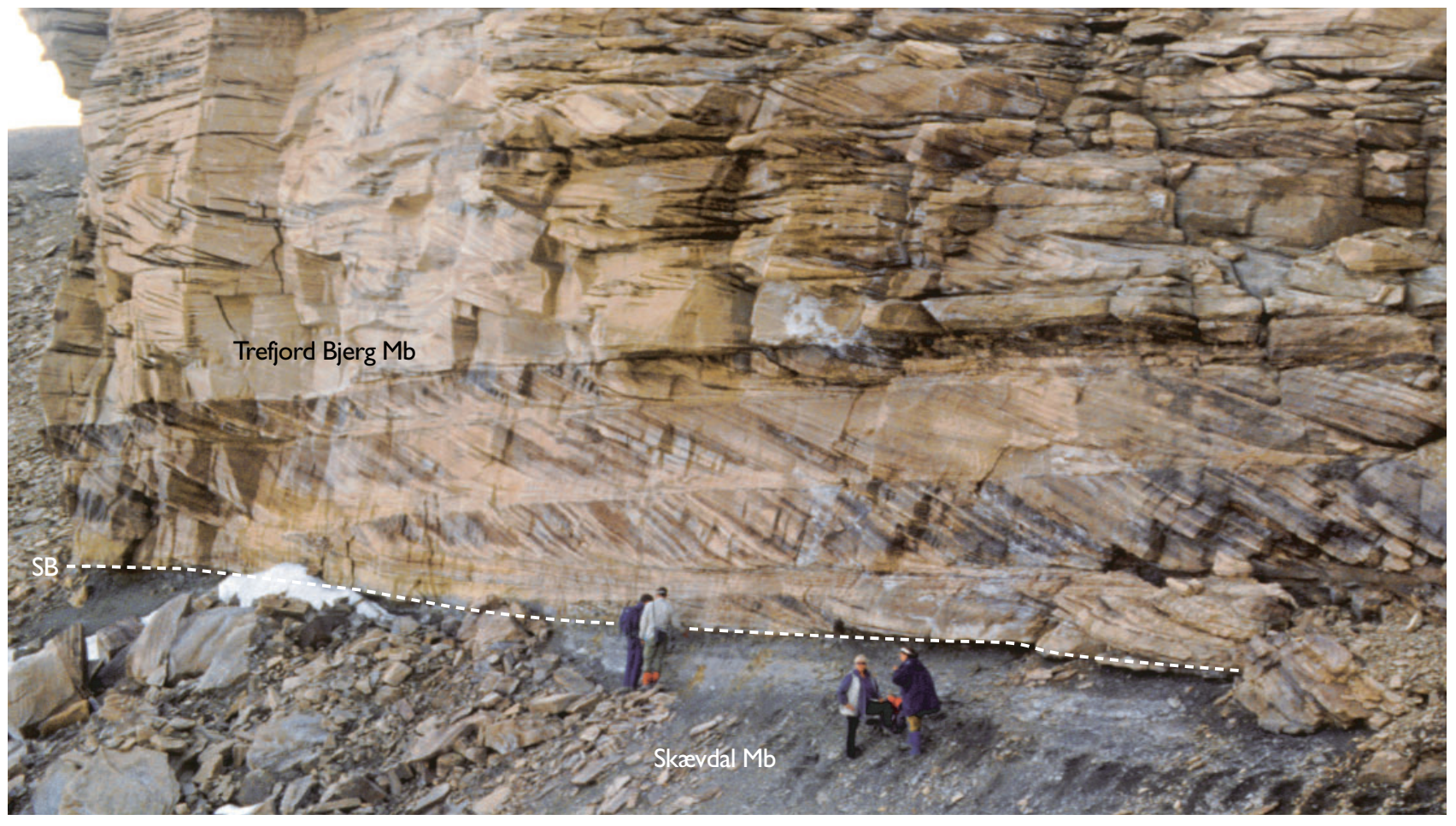

Fig. 14. Tidal sandwave sandstones of the Trefjord Bjerg Member (Ostreaelv Formation). Trefjord Bjerg, eastern central Jameson Land. Note well-developed sequence boundary (SB) where the shallow marine sandstones overlie deeper marine mudstones of the Skævdal Member (Ostreaelv Formation) marked by an erosional unconformity and a seawards shift in facies.

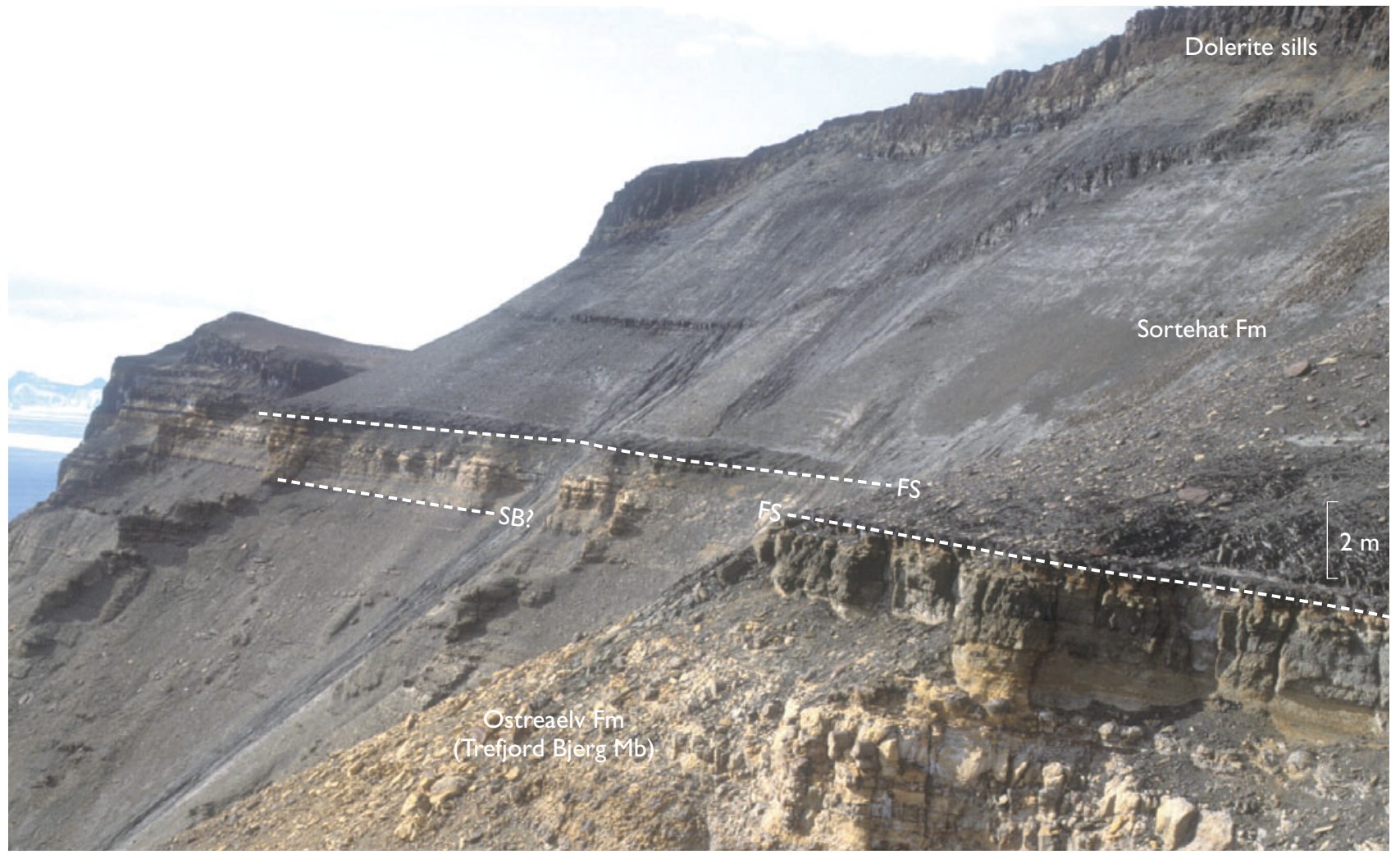

Fig. 15. Sharp flooding surface (FS) where offshore mudstones of the Aalenian - Lower Bajocian Sortehat Formation overlie Toarcian shallow marine sandstones of the Ostreaelv Formation (Trefjord Bjerg Member). Cryptic sequence boundary (SB) is situated some metres below the top of the Ostreaelv Formation. Neill Klinter, south-east Jameson Land. 


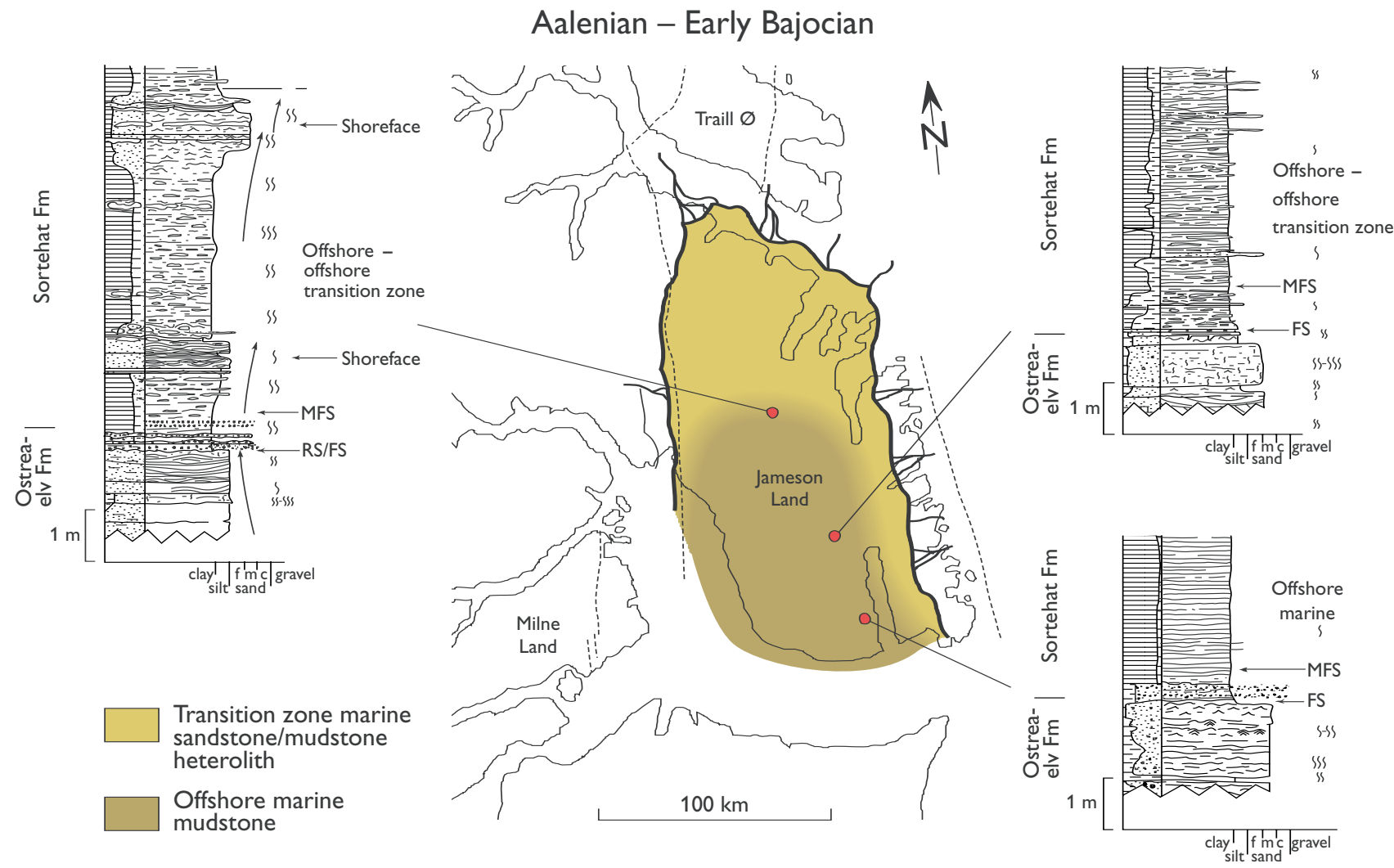

Fig. 16. Aalenian - Early Bajocian palaeogeography (Sortehat Formation) with sections through characteristic facies types. Sections based on Hansen (1999); for legend, see Fig. 6. FS, flooding surface; MFS, maximum flooding surface; RS, ravinement surface.

A new transgressive phase took place in the Early Toarcian (Fig. 13). The tidal channels and lagoonal systems of the previous phase were drowned and offshore transition zone conditions were developed especially in the southern part of the basin. This was followed by renewed progradation of sands deposited in ebb-tidal deltas (Harris Fjeld Member), shoreface (Nathorst Fjeld Member), and tidal channel complexes (Lepidopteriselv Member). The latter is separated from the lagoonal deposits of the underlying Horsedal Member by a marine transgressive surface of erosion.

In the Late(?) Toarcian, a uniform sheet of bioturbated sandy mud and muddy fine-grained sand was deposited throughout the basin (Skæevdal Member; Fig. 14). This landwards shift in facies reflects drowning of the coarser grained depositional systems caused by a relative sealevel rise. It was succeeded by a marked facies change at a sharp boundary to sand deposited in marine shoreface, tidal channels and dune fields (Trefjord Bjerg Member; Fig. 14). The age relations of the last two units are not yet well-resolved; ammonites are scarce and not all precisely located with respect to the lithostratigraphic units. Belemnite data suggest a latest Toarcian $D$. levesquei Chron age for the fine-grained Skævdal Member, whereas ammonites from the base of the member indicate an Early Toarcian D. tenuicostatum Chron age ( $D$. semicelatum Subchron). Palynomorphs suggest a Late Toarcian - Early Aalenian age (Koppelhus \& Dam 2003, this volume). Belemnites from the overlying sandy Trefjord Bjerg Member suggest an age no older than the Latest Toarcian D. levesquei Chron and palynomorphs suggest a Late Toarcian - earliest Aalenian age (Koppelhus \& Dam 2003, this volume); the top of the Trefjord Bjerg Member is of latest Toarcian - earliest Aalenian age according to Underhill \& Partington (1994). Palynomorph age indications are corroborated by new Sr-isotope data (M. Engkilde, personal communication 2000), and the sum of evidence points towards a Late Toarcian - earliest Aalenian age for the two members. Recent work by Hansen (1999), Koppelhus \& Dam (2003, this volume) and Koppelhus \& Hansen (2003, this volume) on the Ostreaelv - Sortehat Formation boundary has demonstrated the presence of an important sequence boundary unconformity in the top part of the Trefjord Bjerg sandstones (top Ostreaelv Formation; Fig. 15).

Underhill \& Partington (1994) suggested that the socalled 'Mid-Cimmerian Unconformity' of the North Sea 
was absent in Jameson Land and that there was a continuous succession over the correlative interval. The new data of Hansen (1999) suggest that the sequence boundary unconformity within the upper Trefjord Bjerg Member is broadly coeval with the 'Mid-Cimmerian Unconformity'; it is important to note, however, that the onset of rifting and the associated change in basin configuration started later in East Greenland (mid-Bajocian) than in the North Sea area, corresponding to the boundary between the Sortehat Formation and the overlying Pelion Formation.

Deposition of the upper sands of the Trefjord Bjerg Member was followed by a major landwards shift in facies represented by a thick coarsening-upwards succession of dark grey to black offshore mudstones and subordinate lower shoreface siltstones and very finegrained sandstones of the Sortehat Formation (Figs 4, $15,16)$. The lower boundary of the formation is a prominent northwards younging ravinement surface. A maximum flooding interval is situated close to the base of the formation to the south; it rises to the north reflecting higher sediment influx from northern source areas (Hansen 1999). Deposition took place in relatively deep water with poor oxygenation at the sea-floor during the early phases as indicated by the sparse macrofauna, low diversity trace fossil assemblage, organic geochemistry and palynomorphs. The lower part of the formation contains salinity tolerant dinocysts and deposition probably took place under brackish-marine conditions (Krabbe et al. 1994; Hansen 1999; Koppelhus \& Hansen 2003, this volume). Accumulation of varying amounts of hydrogen-rich material dominated by the alga Botryococcus caused periodic oxygen deficiency (Hansen 1999). Salinity increased gradually with time, but the low abundance of marine macrofossils seems to reflect dissolution rather than primary absence. Ammonites are absent, but palynomorphs suggest an Aalenian - (?)Early Bajocian age for the formation (Underhill \& Partington 1994; Hansen 1999; Koppelhus \& Hansen 2003, this volume).

\section{J2. Late Bajocian - Hauterivian: main Mesozoic rift phase}

\section{Vardekløft, Hall Bredning and Wollaston Forland Groups}

The most important rift phase in the Mesozoic of East Greenland began in the Late Bajocian, intensified through the Bathonian-Kimmeridgian, culminated in the Middle Volgian, and waned in the Ryazanian-Hauterivian
(Fig. 4). Onset of rifting resulted in the complete reorganisation of basin configuration, drainage patterns and marine transport systems. In Early Jurassic time, the depositional basin was restricted to Jameson Land (Figs 2, 4). Large areas along its western margin in Milne Land and especially in adjacent areas to the north were now transgressed and became part of the depositional basin for the first time since Triassic or older times (Figs 2, 4, 17). The transgressive onlap onto crystalline basement is particularly clearly seen on Milne Land and, to the north, in Wollaston Forland, Kuhn $\varnothing$, Hochstetter Forland and Store Koldewey.

Jameson Land responded to rifting rather differently from the areas further north (Figs 3, 4). It behaved as a single structural entity and was not broken up into narrower, strongly tilted blocks. Subsidence became asymmetrical through slight tilting, however, with main depocentres in the western and north-western part of the basin and with condensation and unconformities towards the south-east and along the eastern margin of the basin. The platform-type subsidence resulted in almost continuous infilling of the new accommodation space added by the gentle tilting. Condensed successions developed in the most distal southern areas, and during the Late Oxfordian - Kimmeridgian sea-level highstand a relatively deep-water basin was formed over southern Jameson Land. The Upper Bajocian Upper Volgian syn-rift succession thus forms an overall regressive-transgressive-regressive cycle. (Note that the Late Volgian is of earliest Cretaceous age and roughly corresponds to the Early Berriasian.) The nature of the boundary between the Jameson Land platform and the basins further north is uncertain. Surlyk (1978a) suggested that it was developed as a NW-trending crossfault along the present day Kong Oscar Fjord between Jameson Land and Traill $\varnothing$, following earlier notions of Bütler (1957) and Donovan (1957). Combined study of satellite images, reflection seismic data and Lower Jurassic facies patterns suggests that the boundary is rather complex and follows a series of deep-seated NW-trending fault splays of probable Devonian age in northernmost Jameson Land (Figs 2, 8; Dam et al. 1995).

Rifting began at roughly the same time in the areas north of Jameson Land. The early phase lasted throughout Late Bajocian(?) - Callovian times with relatively gentle block-tilting. Rifting intensified in the OxfordianKimmeridgian, and the main rift phase took place close to the Early-Middle Volgian transition, accompanied by major block-tilting, formation of high, partly subaerial fault scarps and emergence of footwall crests. Rifting waned in the Late Ryazanian (late Late Berriasian) and 


\section{Late Bajocian}

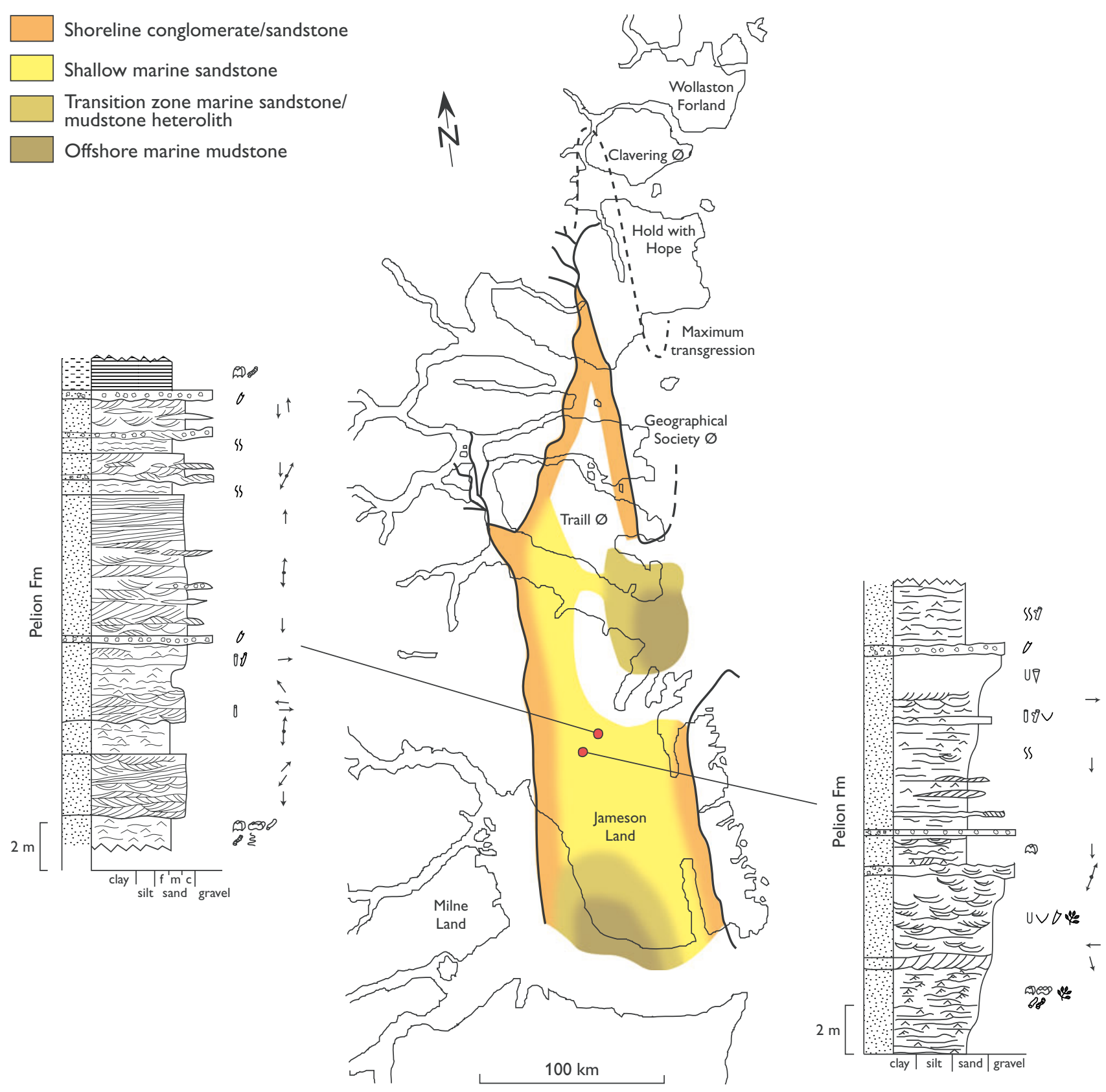

Fig. 17. Late Bajocian palaeogeography (lower Pelion Formation and correlatives) with sections through characteristic facies types. Note major change in extent and configuration of the depositional basin compared to Early Jurassic setting. This reflects initiation of rifting along right-stepping, mainly N-S-trending faults. Sections based on Engkilde \& Surlyk (2003, this volume); for legend, see Fig. 6.

came to an end in the Hauterivian, with minor faulting and fragmentation of blocks (Vischer 1943; Maync 1947, 1949; Surlyk 1978b). The Middle Jurassic - lowermost Cretaceous succession in the areas north of Jameson Land thus shows a stepwise backstepping and deepening represented by the change from shallow marine sand- stones, over deeper water outer shelf and slope mudstones to coarse-grained deep-water slope apron and basin-floor fan systems. This is particularly well illustrated by the succession of the Wollaston Forland area (Surlyk 1978b, 1984, 1989; Surlyk \& Clemmensen 1983). Renewed episodes of probably rift-related faulting 
occurred in Early and early Late Cretaceous times (Surlyk \& Noe-Nygaard 2001a); the Jurassic fault blocks were further fragmented in the Palaeogene and Neogene, and old faults strongly rejuvenated. It is thus rather difficult to identify precisely when the individual faults were active during the long series of rift events, and to estimate the width of the fault blocks at any particular time.

The outline of the basin was controlled by N-S- and NNE-SSW-trending right-stepping en echelon normal faults. This resulted in a northwards tapering of the basin. Sediment was introduced mainly at relay or transfer zones at the points of en echelon take-over (Surlyk 1977b, 1990a, 1991a; Surlyk et al. 1981; Surlyk \& Clemmensen 1983). The overall Middle Jurassic palaeogeography of the region thus had the configuration of two elongate, fault-controlled embayments with their heads in the Clavering $\varnothing$ and Hochstetter Forland areas. However, the exact position of the embayment heads shifted considerably up and down the axes of the embayments, following changes in relative sea level. The head of the southern embayment thus seems to have shifted from a position in western Clavering $\varnothing$ during maximum transgression, as shown by recent finds of Jurassic deposits in Hold with Hope (Vosgerau et al. in press a), to a position many tens of kilometres to the south within a relatively short time interval.

\subsection{Late Bajocian - Middle Bathonian: onset of rifting and marine progradation}

\section{Lower Pelion, Charcot Bugt and Fossilbjerget Formations}

Rift-induced sedimentation began with fluvial pebbly sandstones of the Bristol Elv Formation (Figs 4, 5, 18; Therkelsen \& Surlyk in press). The fluvial deposits reach a thickness of at least $155 \mathrm{~m}$ and may represent the fill of an incised river valley system in the Traill $\varnothing$ area, which had been uplifted and emergent in Early Jurassic time (Surlyk 1977a, 1978a). Fluvial deposition took place under overall base-level rise; peat swamps formed during the last phases of valley filling and are now represented by coaly mudstones. The age of the fluvial succession is not well known, but it shows close lithological resemblance and affinity to the overlying marine sandstones of the Pelion Formation. The presence of the Upper Bajocian C. borealis Chronozone in the lower Pelion Formation suggests a slightly older, probably late Early Bajocian, age for the Bristol Elv Formation. It should be noted, however, that in Jameson Land the lowest $C$. borealis occurs 35-40 $\mathrm{m}$ above the base of the Pelion Formation. The age of these pre-borealis beds is not yet known but they undoubtedly represent the distal, marine correlative of the Bristol Elv Formation.

In Jameson Land, the dark mudstones of the Aalenian - Lower Bajocian Sortehat Formation (top J1.2) are unconformably overlain by shallow marine sandstones of the Pelion Formation (Figs 4, 17, 19). An incised valley has been identified at the base of the Pelion Formation in northern central Jameson Land and the boundary is a regional, low order sequence boundary (Surlyk 1991a; Engkilde 1994; Engkilde \& Surlyk 2003, this volume). The base of the Pelion Formation is nearly isochronous in the Jameson Land - Traill $\varnothing$ area and can be dated to more or less the Late Bajocian C. borealis Chron.

The Pelion Formation is overlain by and passes southwards into silty, micaceous mudstones of the Fossilbjerget Formation (Figs 4, 17, 20). The boundary between the two formations is highly diachronous, younging to the north from the Late Bajocian to the Middle Callovian. It is sharp to the south and becomes more gradational to the north; it is commonly developed as a flooding surface and the formation boundary can be considered a northwards younging succession of shingled flooding or ravinement surfaces.

The Pelion Formation - Fossilbjerget Formation couplet forms a large-scale genetic unit, which thins markedly in a proximal-distal, north to south direction from about 600 to $150 \mathrm{~m}$, but the main decrease in thickness takes place from central to southernmost Jameson Land in the area of sandstone pinch-out. The main sediment entrypoint was originally thought to be situated in southern Hold with Hope (Surlyk 1977b; Surlyk et al. 1981; Surlyk \& Clemmensen 1983). New finds of Middle Jurassic deposits in northern Hold with Hope indicate a northwards extension of the head of the embayment probably to western Clavering $\varnothing$ during times of maximum flooding (Figs 4, 17; Vosgerau et al. in press a). The actual position of the entry point, however, fluctuated considerably in a north-south direction depending on changes in sea level. This is reflected by the pronounced breaks in the succession at Hold with Hope. The basal sandstones of the Pelion Formation in this area are of earliest Callovian C. apertum Chron age, but ammonites of the uppermost Bajocian C. pompeckji Chronozone occur in the basal Cretaceous pebbly sandstone (Vosgerau et al. in press a). This shows that the area was flooded during maximum C. pompeckji Chron transgression and that pre-Callovian Pelion Formation deposits were removed by erosion during one or more Bathonian lowstands. Palaeogeographic maps for the Late Bajocian - Callovian time interval thus necessar- 
ily present snapshots. The position of the coastline and notably of the head of the embayment shifted back and forth for tens to sometimes more than a hundred kilometres following even minor changes in sea level due to the low inclination of the basin floor. The basic model of Surlyk (1977b) and Surlyk et al. (1981), involving structurally controlled embayments with the main sediment entry points at transfer zones between right-stepping en echelon faults, is thus considered still to be valid.

The base of the early syn-rift unit represented by the sandy Pelion Formation (and correlatives) youngs northwards from the Late Bajocian in Jameson Land and
Traill $\varnothing$ to the Late Bathonian/Early Callovian in Hochstetter Forland. The onlapping Pelion sandstones (and correlatives) rest on progressively older rocks in the same direction. Thus they overlie Lower Bajocian strata in Jameson Land, Triassic strata on Trail $\varnothing$, Upper Permian strata in southern Wollaston Forland and crystalline basement rocks in northern Wollaston Forland, Kuhn $\varnothing$ and Hochstetter Forland.

Sand and silt were distributed by marine, southwards flowing, tidally enhanced currents and transported as far south as southern Jameson Land and possibly farther south (Fig. 17). The inclination of the N-S-trend-

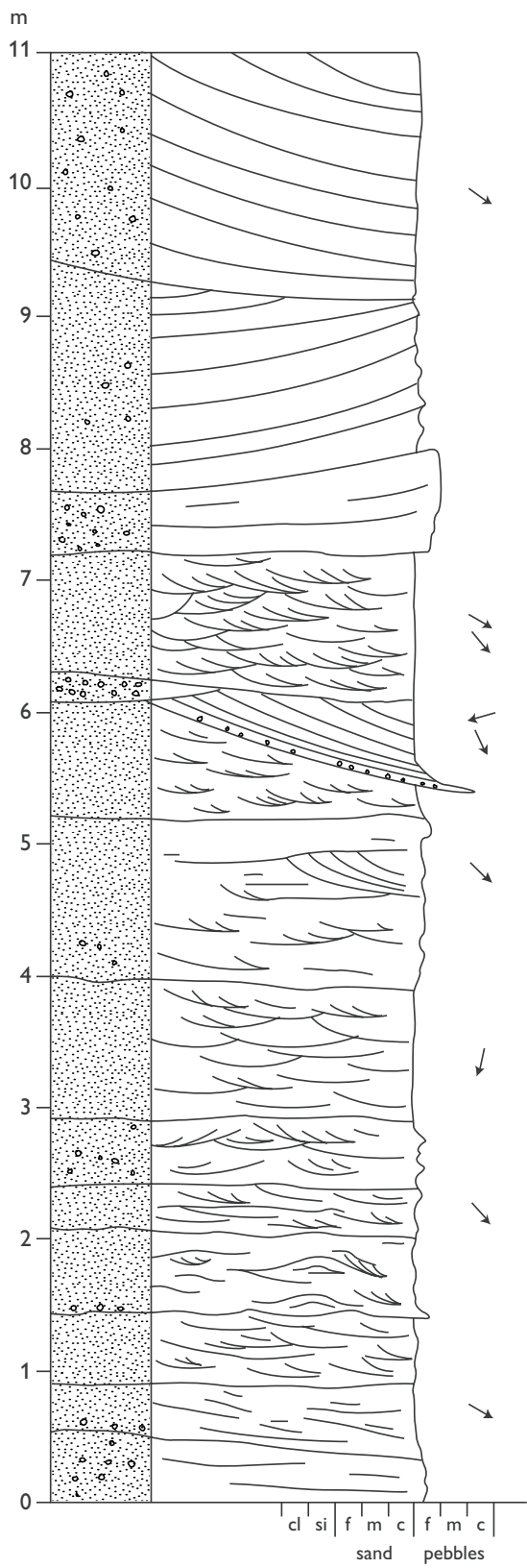

Braided river

m

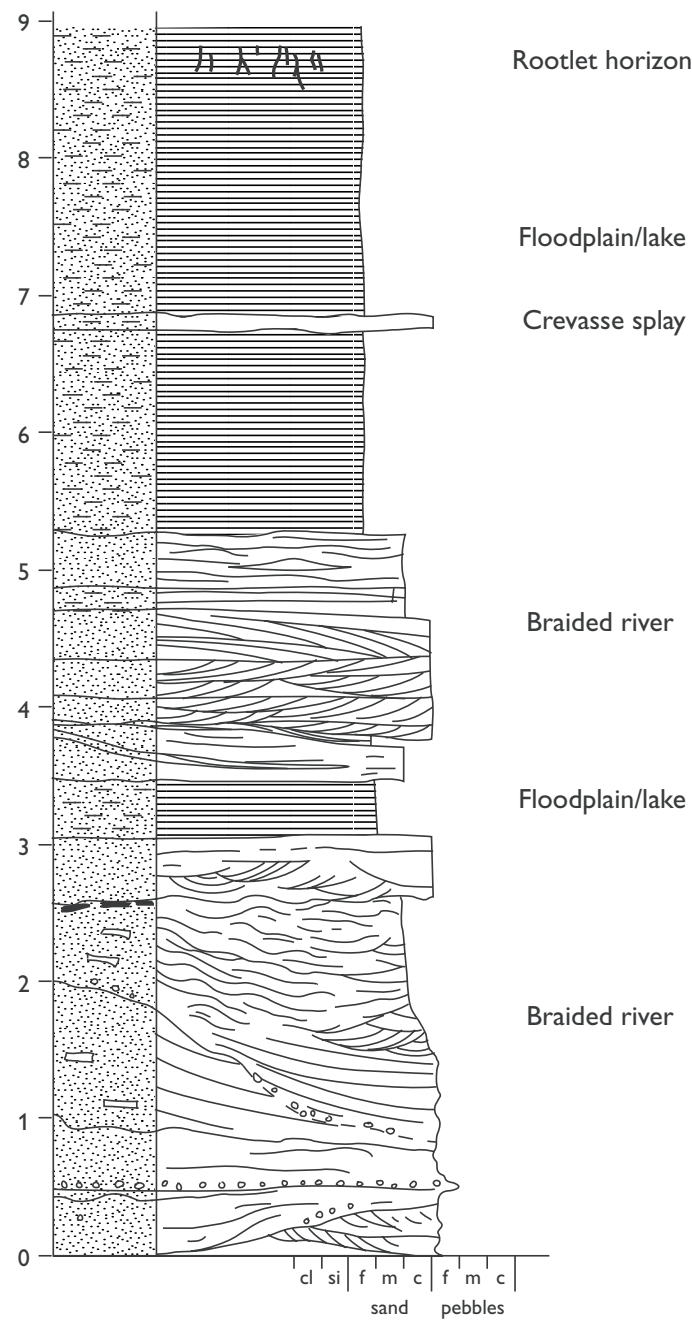

Fig. 18. Sections through Lower Bajocian(?) fluviatile pebbly sandstones of the Bristol Elv Formation. Based on Therkelsen \& Surlyk (in press); for legend, see Fig. 6. 


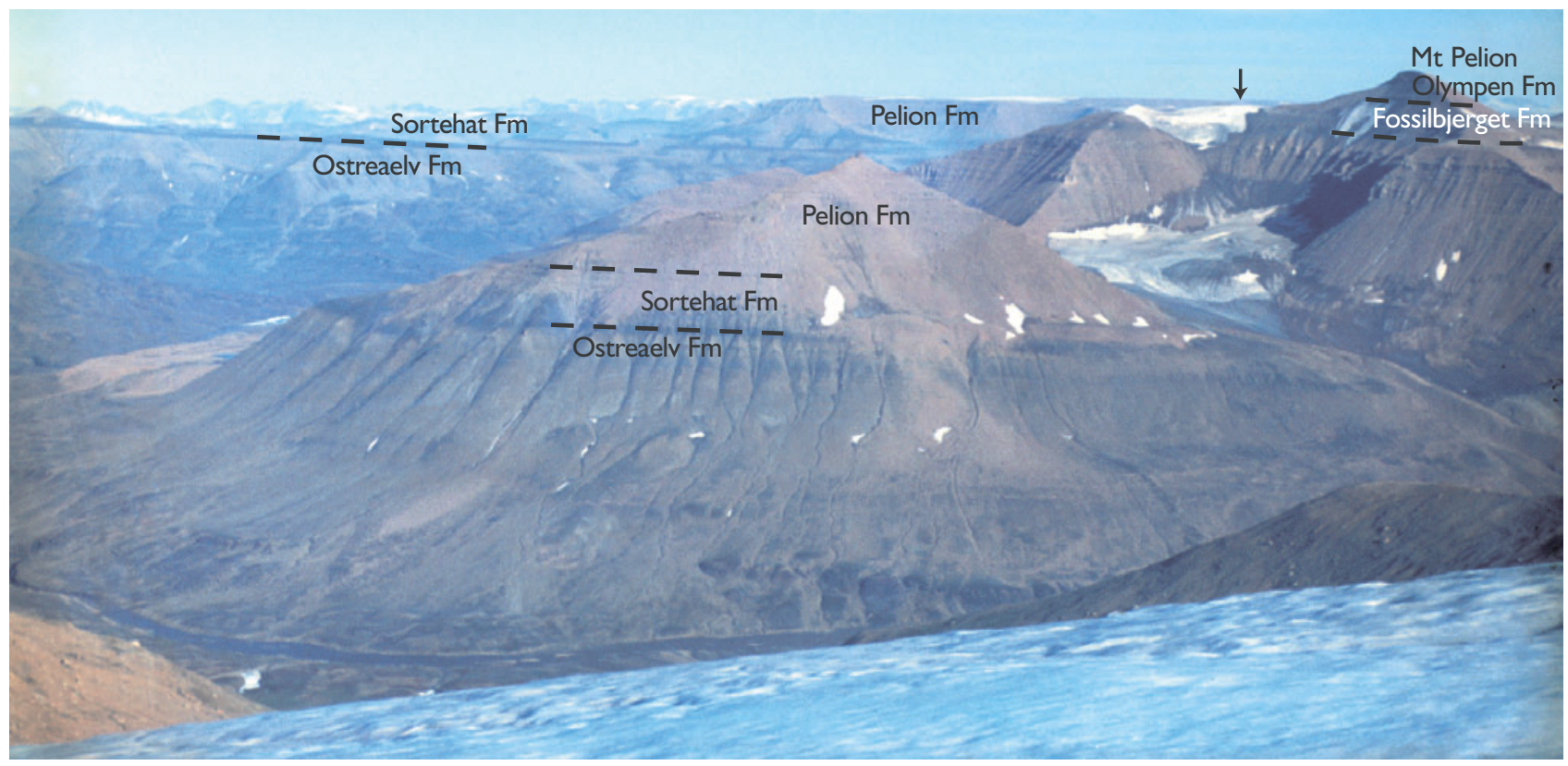

Fig. 19. The mountain of Pelion (1200 m) in northern central Jameson Land showing thickly developed sandstones of the Pelion Formation. View towards ESE. Arrow shows position of section shown on Fig. 21.

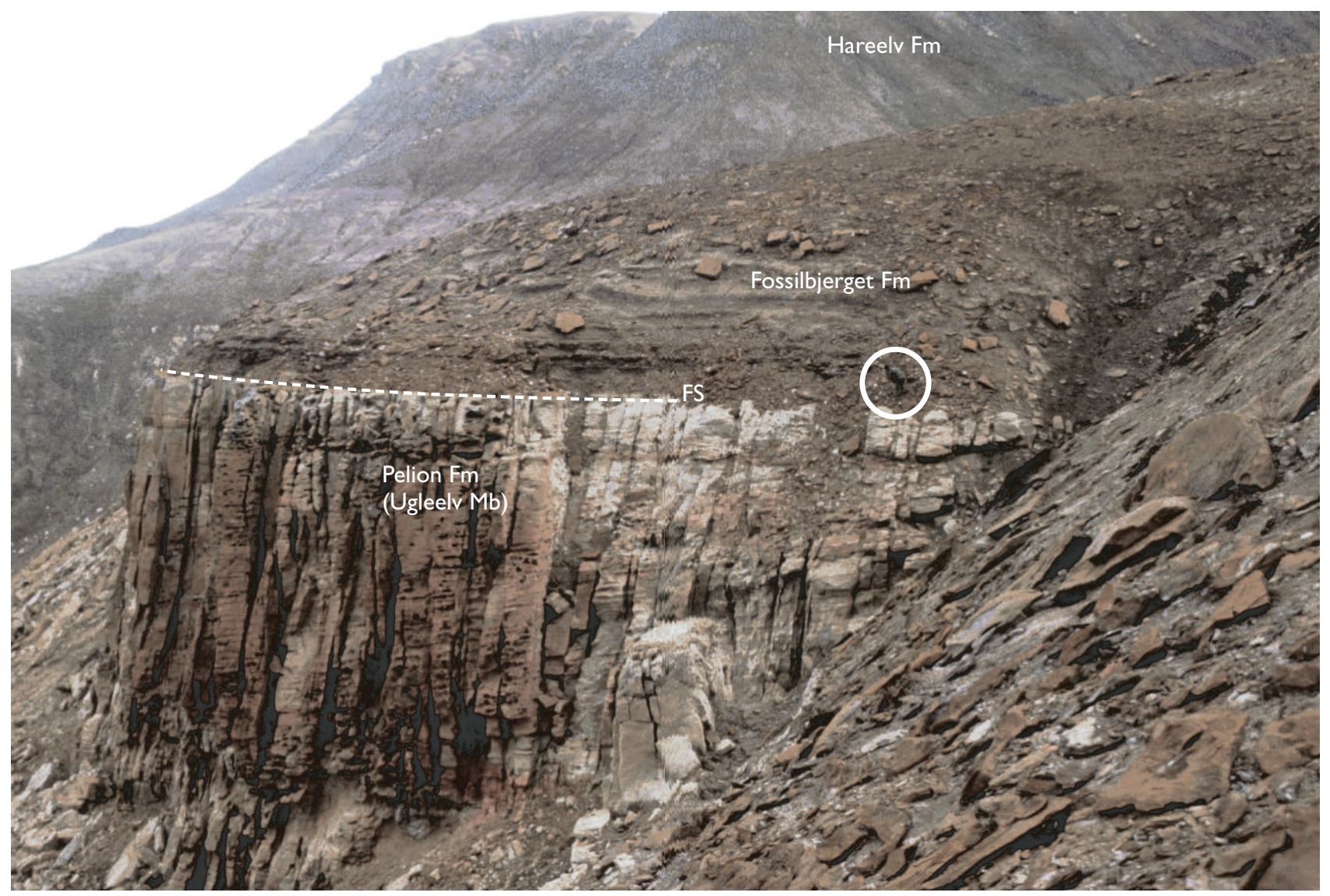

Fig. 20. High-angle clinoform-bedded lowstand wedge sandstones of the Ugleelv Member, lower Pelion Formation (Upper Bajocian). Katedralen, south-east Jameson Land. The wedge is topped by a marked flooding surface (FS) overlain by offshore siltstones of the Fossilbjerget Formation. The formation boundary youngs northwards from the Late Bajocian to the Early Callovian reflecting longterm backstepping and eventual drowning of the shallow marine Pelion sandstone system. Figure (encircled) for scale. 

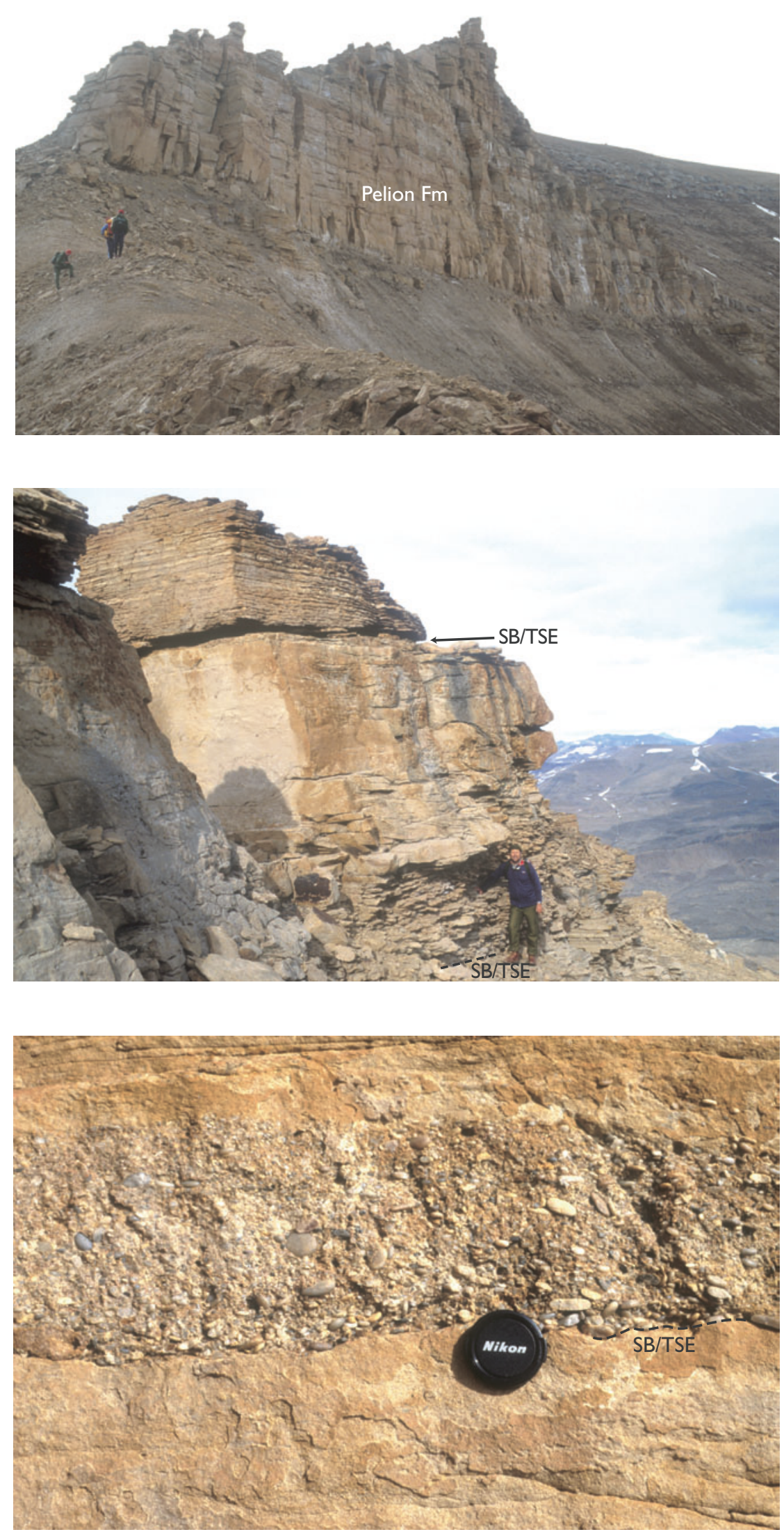

Fig. 21. Thickly developed monotonous Upper Bajocian - Lower Callovian shallow marine sandstones of the Pelion Formation in northern central Jameson Land. Mount Pelion, Jameson Land (see position on Fig. 19)

Fig. 22. Typical simple sequence in the upper Pelion Formation. The geologist stands on lower bounding surface. Degree of bioturbation decreases strongly upwards towards the coincident sequence boundary and transgressive surface of erosion (SB/TSE). Mount Pelion, Jameson Land.
Fig. 23. Lag of well-rounded discoidal quartzite pebbles overlying coincident sequence boundary and transgressive surface of erosion (SB/TSE) at the top of simple sequence, as shown in Fig. 22. Mount Pelion, Jameson Land. 
ing basin axis was very low and deposition was highly sensitive to even small changes in relative sea level or sediment influx. Shoreline progradation or retreat over tens to hundreds of kilometres could thus take place within the resolution of single ammonite faunal horizons (durations down to $100 \mathrm{ka}$; Heinberg \& Birkelund 1984; Callomon 1993, 1994; Engkilde \& Surlyk 2003, this volume).

The Pelion-Fossilbjerget couplet has a uniquely resolved Middle Jurassic ammonite record (Callomon 1993), which allows a detailed sequence stratigraphic breakdown of the thick, rather monotonous sandstone succession (Engkilde 1994; Engkilde \& Surlyk 2003, this volume). The Pelion Formation consists almost exclusively of sandstones and subordinate pebbly sandstones of shoreface and shelf origin (Figs 19, 20, 21, 22). Any fluvial, beach and foreshore deposits were generally eroded in the marine transgressive shoreface during sea-level rise. The Fossilbjerget Formation includes the correlative fine-grained offshore transition zone to offshore siltstones and mudstones.

The dominant depositional motif of the Pelion sandstones is a coarsening-upwards sand-dominated shoreface succession commonly capped by a cemented flood- ing surface (Fig. 22). The lower part is burrow-mottled, while the higher parts have preserved physical sediment structures. The top is normally erosional, commonly with a lag of flat, disc-shaped, well-rounded, quartzite pebbles, and locally a high concentration of ammonites or belemnites (Fig. 23). The unit superficially resembles a parasequence bounded by flooding surfaces but the nature of the pebble-lag conglomerates and especially the pebble shapes, indicative of beach swash and backwash, suggest that a high-energy beach bypassed the area during sea-level fall, depositing a relatively thick layer of foreshore pebbly sand. Fluvial and beach deposits were reworked during subsequent transgression and the top surface of the coarsening-upwards unit is interpreted as a coincident sequence boundary, marine transgressive surface of erosion, and in some cases a maximum flooding omission surface. The units are accordingly interpreted as simple high-order sequences.

A total of 28 high-order sequences with average durations of about $360 \mathrm{ka}$ are recognised and are grouped into eight composite lower order sequences termed P1-8 (P for Pelion) with an average duration of 1-2 Ma (Engkilde \& Surlyk 2003, this volume). The Upper

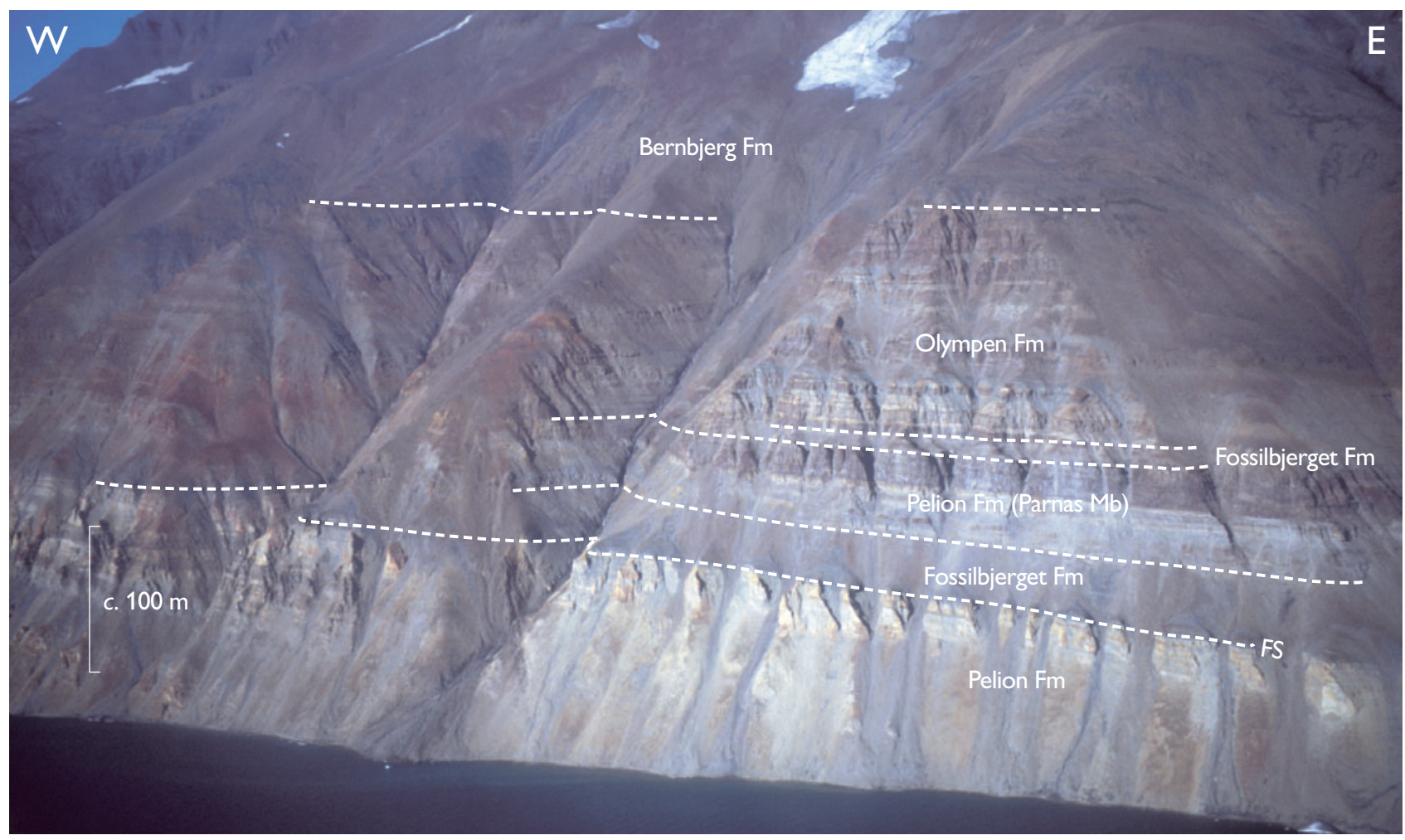

Fig. 24. South coast of eastern Traill $\varnothing$ showing Pelion, Fossilbjerget, Olympen and Bernbjerg Formations deposited on an eastwards tilted fault block. FS, flooding surface. 
Bajocian P1-2 sequences (C. borealis, C. indistinctus, C. pompeckji and lower $A$. arcticus Chronozones) consist predominantly of siltstones and very fine-grained sandstones, and include the most basinally positioned shallow marine sandstones, which were deposited during major sea-level lowstands. They are cut out towards the east by the rocks of the C. greenlandicus Chronozone. Progradation reached southernmost Jameson Land where the basal Pelion Member consists of a coarsening-upwards siltstone-sandstone package (Fig. 20). Its lower boundary above the mudstones of the Sortehat Formation is difficult to identify correctly. However, the top Sortehat mudstones coarsen upwards into a thin sandstone unit. This is overlain by the basal siltstones of the Pelion Formation, which coarsen upwards into sandstones capped by a marine flooding surface. During succeeding transgressive and especially highstand time intervals, deposition was restricted to the northern, more proximal parts of the elongate basin. The overlying Upper Bajocian - Middle Bathonian P3-4 sequences (upper $A$. arcticus, $A$. greenlandicus and lower $A$. ishmae Chronozones) stack aggradationally.

The same pattern can be recognised in central Traill $\varnothing$ but the succession is thinner probably reflecting proximal bypass during lowstands. In south-eastern Traill $\varnothing$, onset of rifting resulted in eastwards-tilting of a fault block, unusual for East Greenland where virtually all Jurassic fault blocks dip to the west (Fig. 24; Donovan 1957; Carr 1998; Vosgerau et al. in press b). The facies on this block change from proximal to distal towards the east (Fig. 26). This suggests that the Liverpool Land High, which formed the eastern border of the Jameson Land Basin did not extend further north into the offshore area east of Traill $\varnothing$. In the Wollaston Forland area, the Pelion Formation may be up to about 500 m thick but is poorly dated and the figure includes the Payer Dal Formation, which may be up to $150 \mathrm{~m}$ thick. The monotonous sandstone succession shows few if any well-developed cycles or stacking patterns. Sediment influx seems to have been so high that available accommodation space was continuously being filled and the succession can be considered an amalgamated multistorey package. Deposition took place under strong tidal influence with dominance of ebb currents towards the south-west (Surlyk \& Clemmensen 1983; Alsgaard et al. 2003, this volume).

\subsection{Late Bathonian - Middle Callovian: early rifting and backstepping of the sandy marine systems}

\section{Upper Pelion - Charcot Bugt-Fossilbjerget Formations}

The succeeding three sequences of the Pelion Formation (P5-7, upper A. ishmae - S. calloviense Chronozones) show large-scale Late Bathonian to Early Callovian backstepping over several hundred kilometres (Fig. 25). A short regressive pulse took place in the Early Callovian marked by southwards progradation of a sandy wedge to central Jameson Land (Parnas Member, C. apertum - C. nordenskjoeldi Chronozones), but the sandy Pelion system was eventually drowned in the Middle Callovian and became draped with offshore muds of the Fossilbjerget Formation, which show condensed levels and hiatuses in the most distal offshore parts in southern Jameson Land.

Backstepping was probably governed by increased rates of rifting, with onset of gentle block tilting acting in concert with a late Middle Jurassic eustatic sea-level rise. A similar sequential development can also be recognised further north in the Traill $\varnothing$ and Wollaston Forland areas, but the preserved sediments are more proximal and sand-dominated, and drowning events are less clearly marked (Alsgaard et al. 2003, this volume).

The progressive Middle Jurassic northwards transgressive onlap first reached Kuhn $\varnothing$ and Hochstetter Forland in Late Bathonian - Early Callovian times (Figs 4,25 ). The oldest sediments are fluvial conglomerates and pebbly sandstones of the Bastians Dal Formation, which fill a valley system apparently incised in the crystalline basement or formed by the down-tilted western part of the fault block (Fig. 4; Alsgaard et al. 2003, this volume). The overlying coal-bearing deposits on Kuhn $\varnothing$ and Hochstetter Forland constitute the Upper Bathonian? - Middle Callovian Muslingebjerg Formation (Figs 4, 5; Clemmensen \& Surlyk 1976; Petersen et al. 1998). Fluvial deposition began during early base-level rise reflecting the ongoing transgression, and the precursor peat swamps of the coal beds were formed when the valley system was almost completely filled. The coal beds in Hochstetter Forland are interbedded with marine shoreface sandstones and the succession can be subdivided into four high-order sequences each beginning with a thick coal seam resting on a rooted paleosol (Fig. 26; Petersen et al. 1998). Peat accumulation took place during the onset of base-level rise and the coal beds represent the lower part of the transgressive systems tract. The overlying shoreface sandstones form the upper part of the transgressive systems tract and the 


\section{Late Bathonian}

Shallow marine sandstone

Transition zone marine sandstone/ mudstone heterolith

Offshore marine mudstone

ㅁ. Localised coal seams

Palaeocurrents

$N$
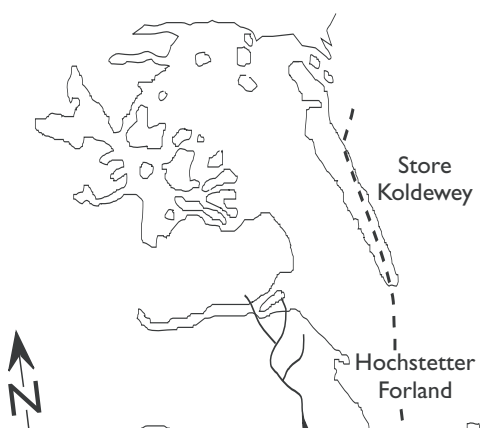

Fig. 25. Late Bathonian palaeogeography (upper Pelion and Fossilbjerget Formations and correlatives) with schematic sections showing the proximal-distal facies development (sections from Engkilde \& Surlyk 2003, this volume). Note northwards backstepping of the sandy shallow marine Pelion system by comparison with Fig. 17. Based on Surlyk (1977b, 1990a), Surlyk et al. (1981) and Vosgerau et al. (in press a); for legend, see Fig. 6.
Proximal

to

distal

facies

changes 


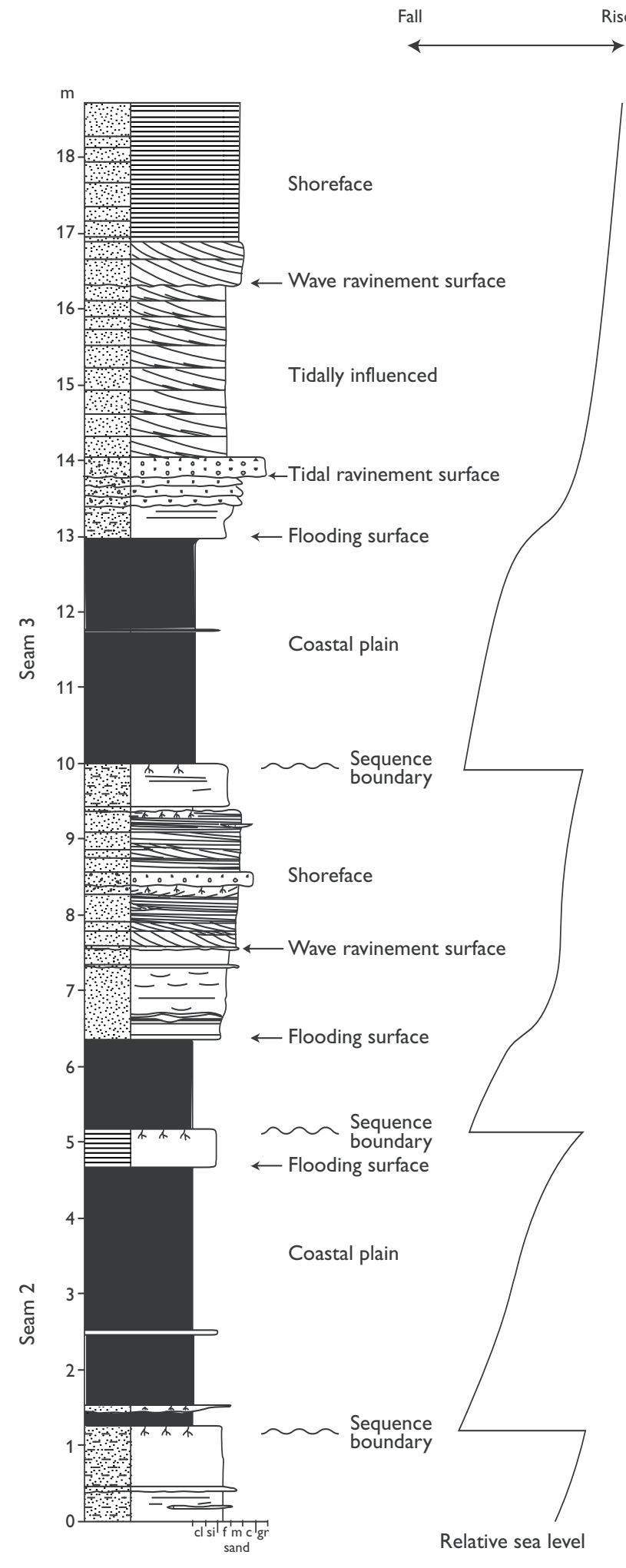

progradational highstand systems tract. So-called 'dullingupwards' cycles in the coal beds represent parasequences or possibly higher order sequences (Fig. 26). The final valley-fill stage, including formation of peat
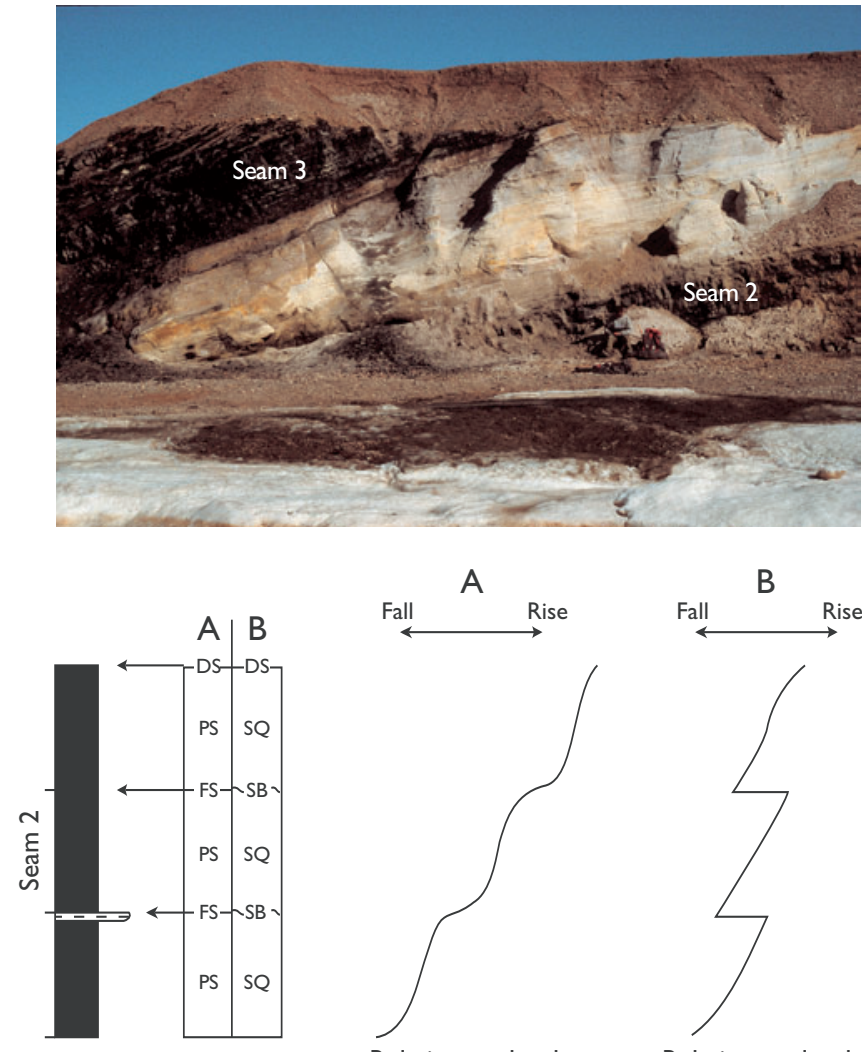

A

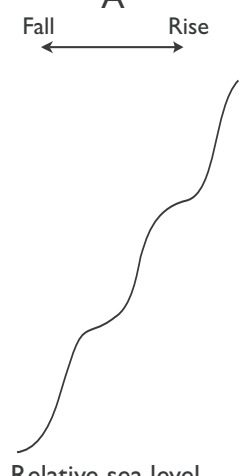

Relative sea level
B

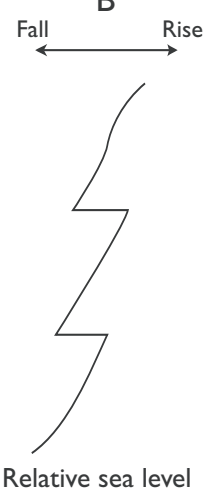

Relative sea level
Higher order cycles

Fig. 26. Coal-bearing succession of the Upper Bathonian(?) Lower Callovian Muslingebjerg Formation at the head of the rifted embayment in Hochstetter Forland showing a sequence stratigraphic interpretation. On the right, two alternative highresolution sequence stratigraphic interpretations are given of dulling-upwards cycles in coal seam 2: the cycles can be interpreted either as a backstepping parasequence set (A) or as a backstepping composite sequence (B) consisting of simple sequences. SQ, sequence; $\mathbf{S B}$, sequence boundary; PS, parasequence; FS, flooding surface; DS, drowning surface. Based on Petersen et al. (1998); for legend, see Fig. 6.

swamps, was succeeded by marine flooding in the Late Callovian and deposition of shoreface and shelf sandstones of the Payer Dal Formation. 
Farthest to the north, on Store Koldewey, crystalline basement is onlapped by Middle Bathonian to Lower Callovian sandstones of the Pelion Formation ( $A$. ishmae, A. cranocephaloide, C. apertum and P. koenigi Chronozones). The upper part of the succession is a correlative of the Spath Plateau Member of Hold with Hope (Piasecki et al. in press).

A spectacular sandy succession is found to the south in Milne Land (Charcot Bugt Formation) where it onlaps crystalline basement (Figs 4, 5; Callomon \& Birkelund 1980; Larsen 1995; Larsen et al. 2003, this volume). The formation is dominated by thick, high-angle clinoform beds which may represent ebb tidal deltas or possibly shelf-margin deltas or wedges, as they give way distally to, and are overlain by, grey deep-water mudstones of the lower Kosmocerasdal Member (Kap Leslie Formation) which is the western correlative of the Fossilbjerget Formation of southern Jameson Land (Fig. 4). The main basin margin fault of northern and central Jameson Land trends north-south and probably continues offshore into Hall Bredning between Milne Land and southern Jameson Land (Fig. 2). The Milne Land succession thus seems to occupy a position over the footwall forming the western border of the wide Jameson Land block, which was gradually down-tilted towards the west. If this interpretation is correct, it corroborates the interpretation of the Charcot Bugt clinoform beds as shelf-margin wedges deposited on a depositional slope below wave base. Very similar deposits form a stack of shelf-edge sand bodies in the Volgian of southern Jameson Land (Surlyk \& Noe-Nygaard 1991, 1995).

Backstepping of the Pelion Formation was probably governed by increasing rates of rifting, block tilting, and deepening of the water over the hanging wall, acting in concert with a late Middle Jurassic eustatic sealevel rise (Hallam 1988; Haq et al. 1988). The main depositional motif in the northern areas was similarly a stepwise backstepping of progradational, coarseningupwards sandstone-dominated packages separated by drowning surfaces.

\section{J2.3. Late Callovian - Middle Oxfordian: renewed marine progradation}

\section{Olympen - upper Charcot Bugt-Jakobsstigen- Payer Dal Formations}

The large-scale regional drowning of the sandy marine Pelion system in the Middle Callovian was succeeded by progradational episodes in the latest Callovian and
Middle Oxfordian (Fig. 27). At this time, the basin topography in the Jameson Land area changed from a ramp to a shelf-break type. The shelf was located over Traill $\varnothing$ and northern Jameson Land, the E-W-trending shelfbreak was situated in northern central Jameson Land, and the relatively deep-water basin in southern Jameson Land (Fig. 28). The first regressive event was heralded by the incoming of thick massive sands (Upper Callovian Athene Member of the Olympen Formation, P. atbleta Chronozone; Fig. 29). They were triggered from the front of a sandy shelf-margin wedge and transported by sediment gravity flows to the base of slope. The rather uniform massive sandstones belong to an undifferentiated late highstand - falling stage - lowstand systems tract, and a sequence boundary cannot be identified. They are sharply overlain by a thick succession of black mudstones (Hades Member, Olympen Formation, Lower - lower Middle Oxfordian, including the Q. mariae Chronozone), and the boundary is interpreted as a drowning surface, which probably passes updip into the transgressive surface formed by drowning of the shelf-margin wedge (Larsen \& Surlyk 2003, this volume).

The Hades Member mudstones contain a maximum flooding surface of Early Oxfordian, Q. mariae Chron age (Fig. 29). They are overlain by the second unit of parallel bedded to massive base-of-slope sandstones, probably of late highstand origin, which are sharply overlain by shallow marine delta front sandstones belonging to the falling stage and lowstand systems tract. This upper sandstone unit forms the Zeus Member of the Olympen Formation (Lower-Middle Oxfordian, Q. mariae-C. densiplicatum Chronozones). Key surfaces are difficult to identify, and a sequence stratigraphic interpretation is hampered by the deep-water nature of most of the succession. The correlative deposits on Traill $\varnothing$ to the north consist of shallow marine sandstones. Similar progradational phases occur in Milne Land at the western basin margin where they are represented by the top of the shallow marine Charcot Bugt Formation (Figs 4, 5; Callomon \& Birkelund 1980; Larsen et al. 2003, this volume).

The Late Callovian and Middle Oxfordian regressive pulses can also be recognised in the areas further north where the succession is developed in shallow marine facies. In southern Wollaston Forland, the tidally influenced high-energy Pelion sandstones are sharply overlain by the finer-grained, cyclic and somewhat enigmatic Lower-Middle Oxfordian Jakobsstigen Formation (Figs 28, 30; Bojesen-Koefoed et al. 1997; Vosgerau et al. 2000). The cycles are a few metres thick and consist of 


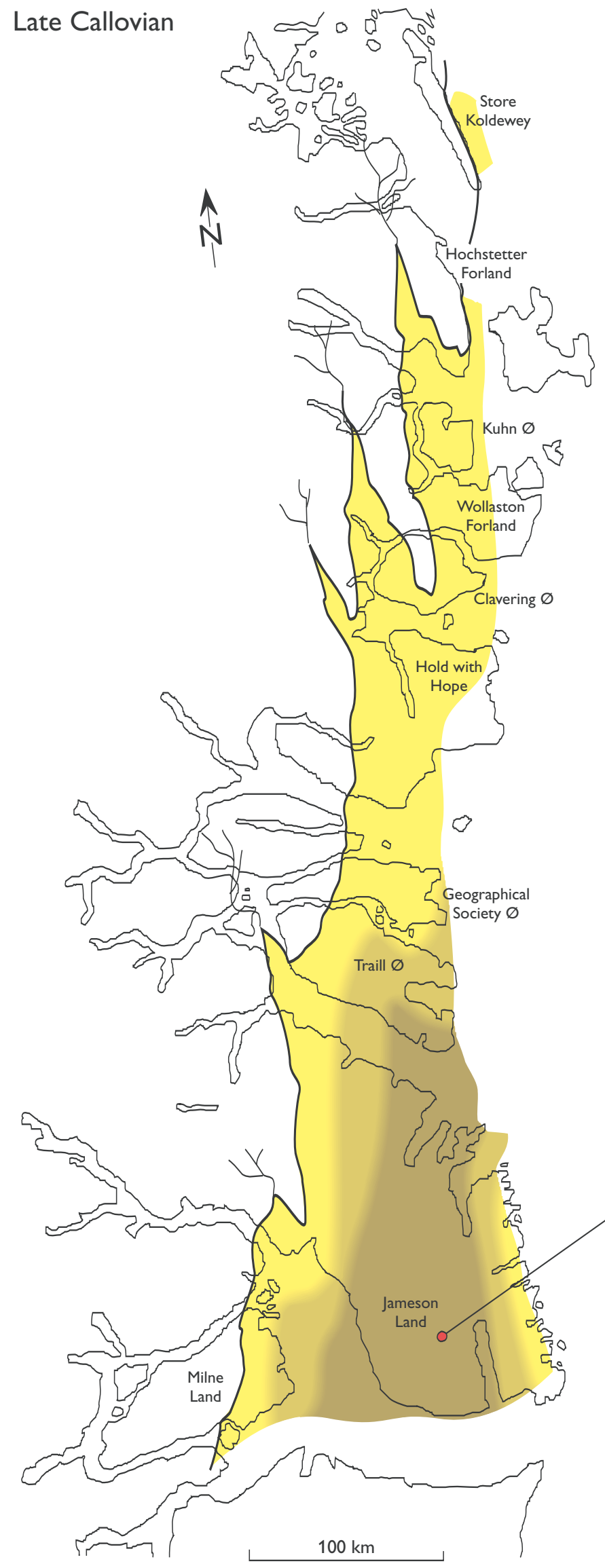

Fig. 27. Late Callovian palaeogeography (top Pelion Fossilbjerget Formation level) with section through characteristic facies types. Note maximum drowning of the sandy shallow marine Pelion system. Based on Surlyk (1977b, 1990a), Surlyk et al. (1981) and Vosgerau et al. (in press a); section based on Engkilde \& Surlyk (2003, this volume). For legend, see Fig. 6.

Shallow marine sandstone

Transition zone marine sandstone/ mudstone heterolith

Offshore marine mudstone

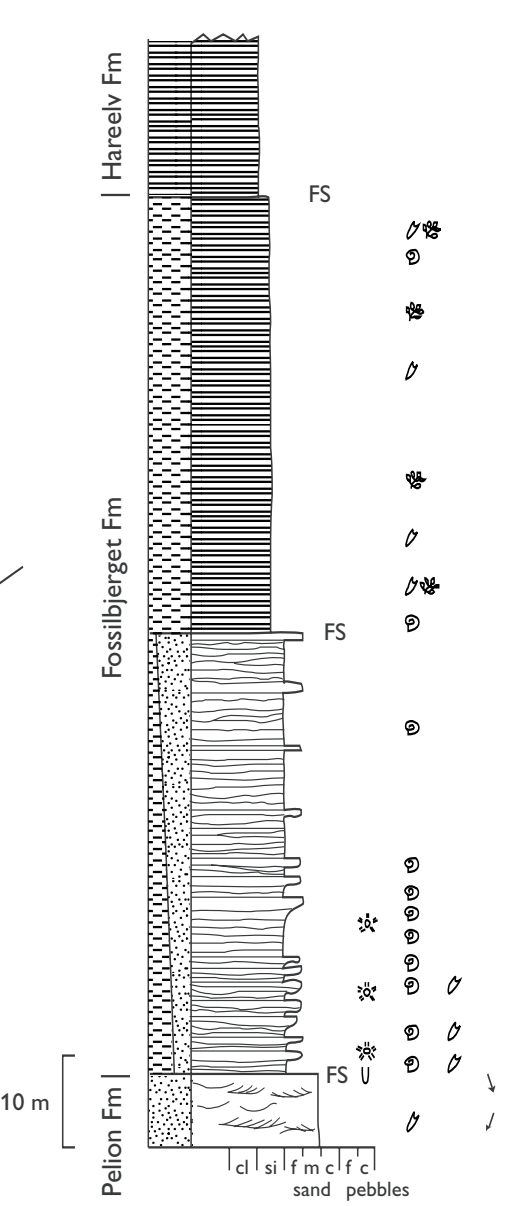




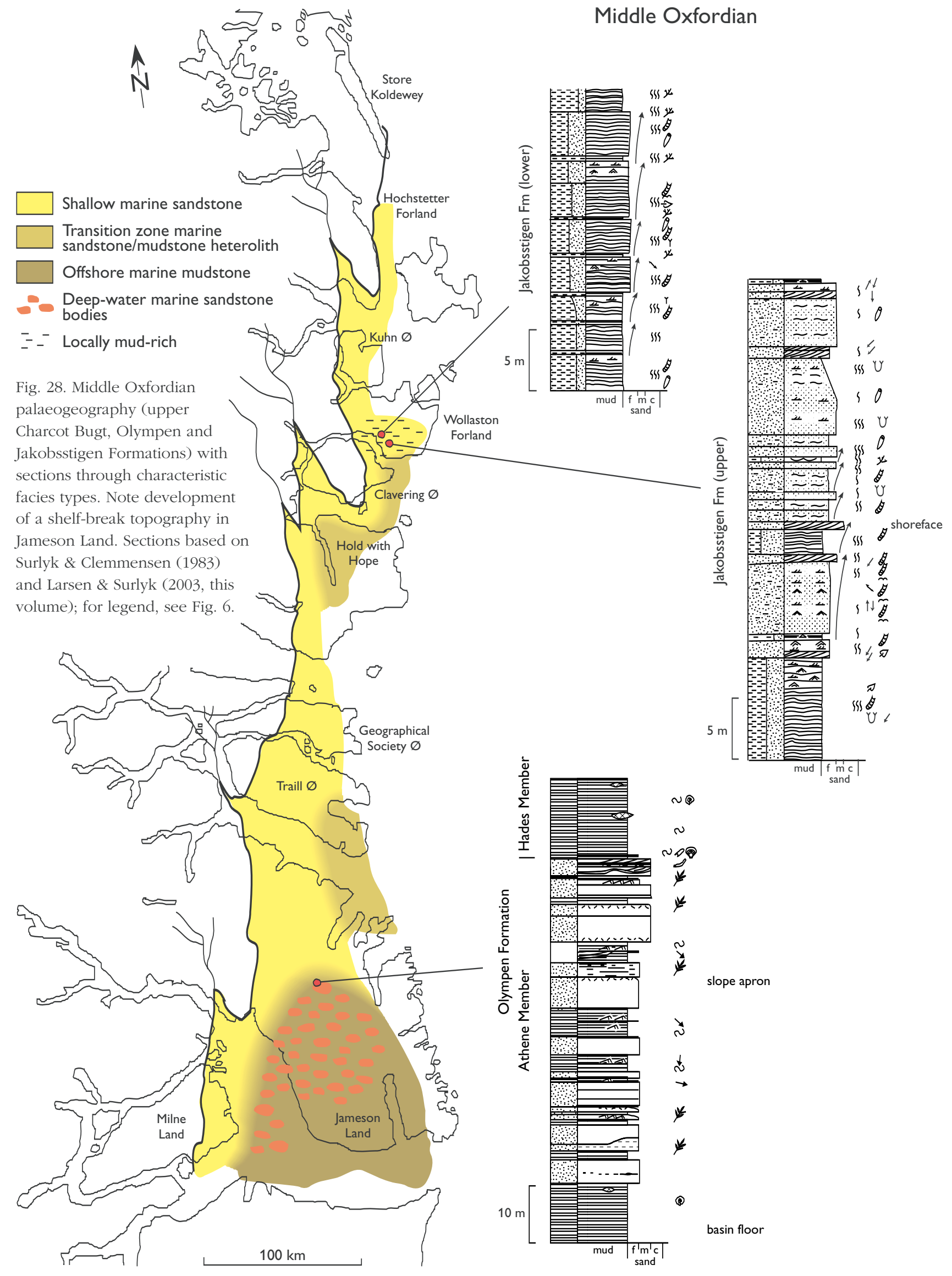




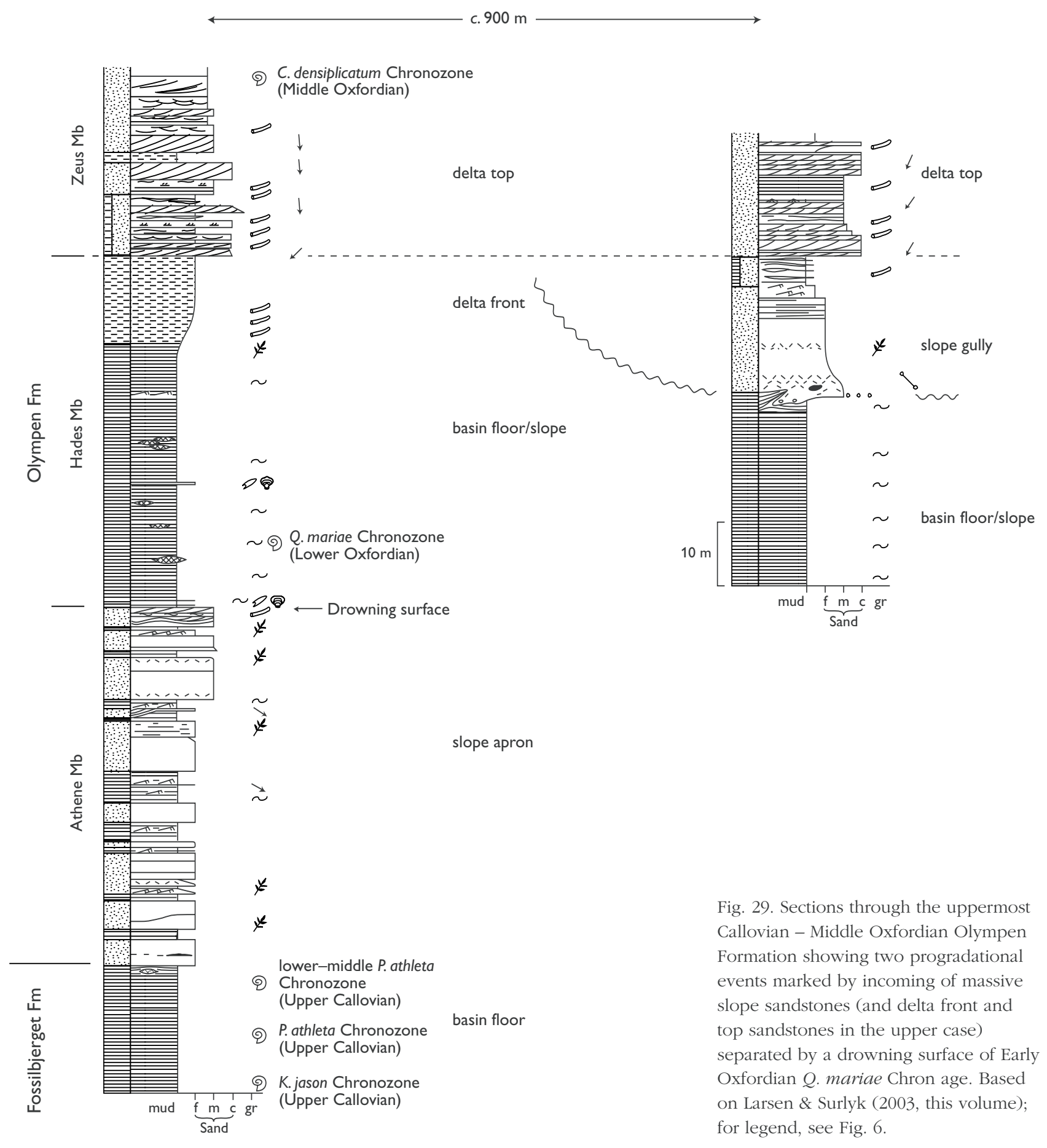

thin, sharp-based, dark, organic-rich, laminated mudstones overlain by marine coarsening-upwards, burrowed heteroliths and sandstones. The mudstones do not contain marine micro- or macrofossils and organic geochemistry also suggests terrestrial deposition. Chondrites burrows are conspicuous in the dark mudstones but they are filled with light sand from the overlying shoreface deposits and were thus formed after marine flooding. The organic material of the mudstones includes two populations of organic carbon particles formed by ground fires and high-temperature wild fires. The heteroliths and overlying, commonly cross-bedded, sandstones were deposited under fully marine offshore transition zone and shoreface conditions.

The rhythmic alternation between the two facies was caused by relatively high-frequency sea-level fluctua- 
tions (Vosgerau et al. 2000). The erosional bases of the organic-rich mudstones represent high-order sequence boundaries formed during the lowest stand of sea level. The mudstones were deposited in lakes on a flat, lowlying coastal plain during onset of base-level rise. Accelerated base-level rise resulted in marine flooding and termination of coastal plain mud deposition; the overlying marine sandy deposits were deposited during highstand progradation. The organic carbon particles show that groundfires and crownfires were common during early base-level rise, when the area was the site of a lowlying coastal plain with shallow-water lakes. In contrast there are no indications of wildfires during the time of marine highstand deposition. It may thus be speculated that the high-frequency sea-level fluctuations were associated with climatic humid-dry cycles and that the crown fires were associated with the transitional period between the two climatic regimes (Bojesen-Koefoed et al. 1997; Vosgerau et al. 2000). These observations accord well with General Circulation Models (GCMS), which show the area to have very wet winters and very dry summers (Sellwood et al. 2000). The wet season would be expected to start with major storms and lightning strikes, starting forest fires. The high-frequency cycles stack into two lower order coarsening-upwards cycles, which may be correlatives of the two progradational cycles of the Olympen Formation in Jameson Land.

Sandstones with pebbly lags of the Payer Dal Formation have recently been identified at Hold with Hope (Vosgerau et al. in press a). They are of Late Oxfordian A. glosense Chron age and overlie Pelion Formation sandstones of Late Callovian pre- $P$. athleta Chron age. This suggests the presence of a hiatus, another example of the incomplete nature of the succession at the head of the southern embayment.

Further north on southern Kuhn $\varnothing$, the Upper Callovian - Middle Oxfordian deposits are developed in fully marine facies. The sandstones of the Pelion Formation are overlain by a coarsening-upwards succession of offshore transition zone heteroliths to shoreface sandstones of the Payer Dal Formation (Fig. 31). The age of this unit is not well-known but dinocyst data suggest a Middle or Late Callovian - Late Oxfordian age. In Hochstetter Forland, the coal-bearing Muslingebjerg Formation is directly overlain by the marine sandstones of the Payer Dal Formation, the base of which is dated to the Late Callovian P. athleta Chron, whereas the Late Oxfordian $A$. glosense or $A$. serratum Chrons have been demonstrated high in the formation (Sykes \& Surlyk 1976; Petersen et al. 1998).

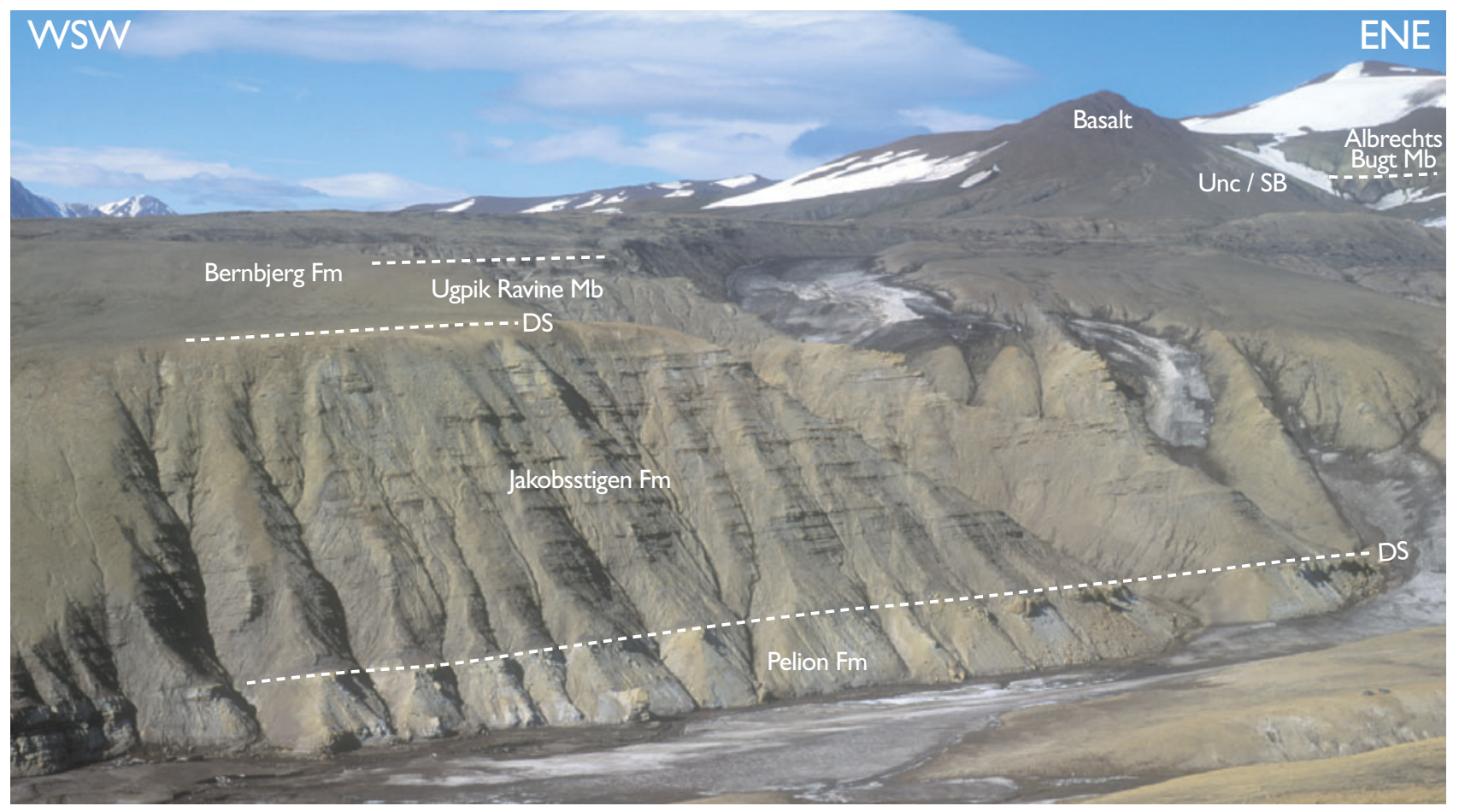

Fig. 30. The north slope of the valley of Cardiocerasdal, Wollaston Forland, showing stepwise backstepping progradational units of the Middle-Upper Jurassic Pelion, Jakobsstigen and Bernbjerg Formations separated by major drowning surfaces (DS). Unc/SB, unconformity/sequence boundary. 


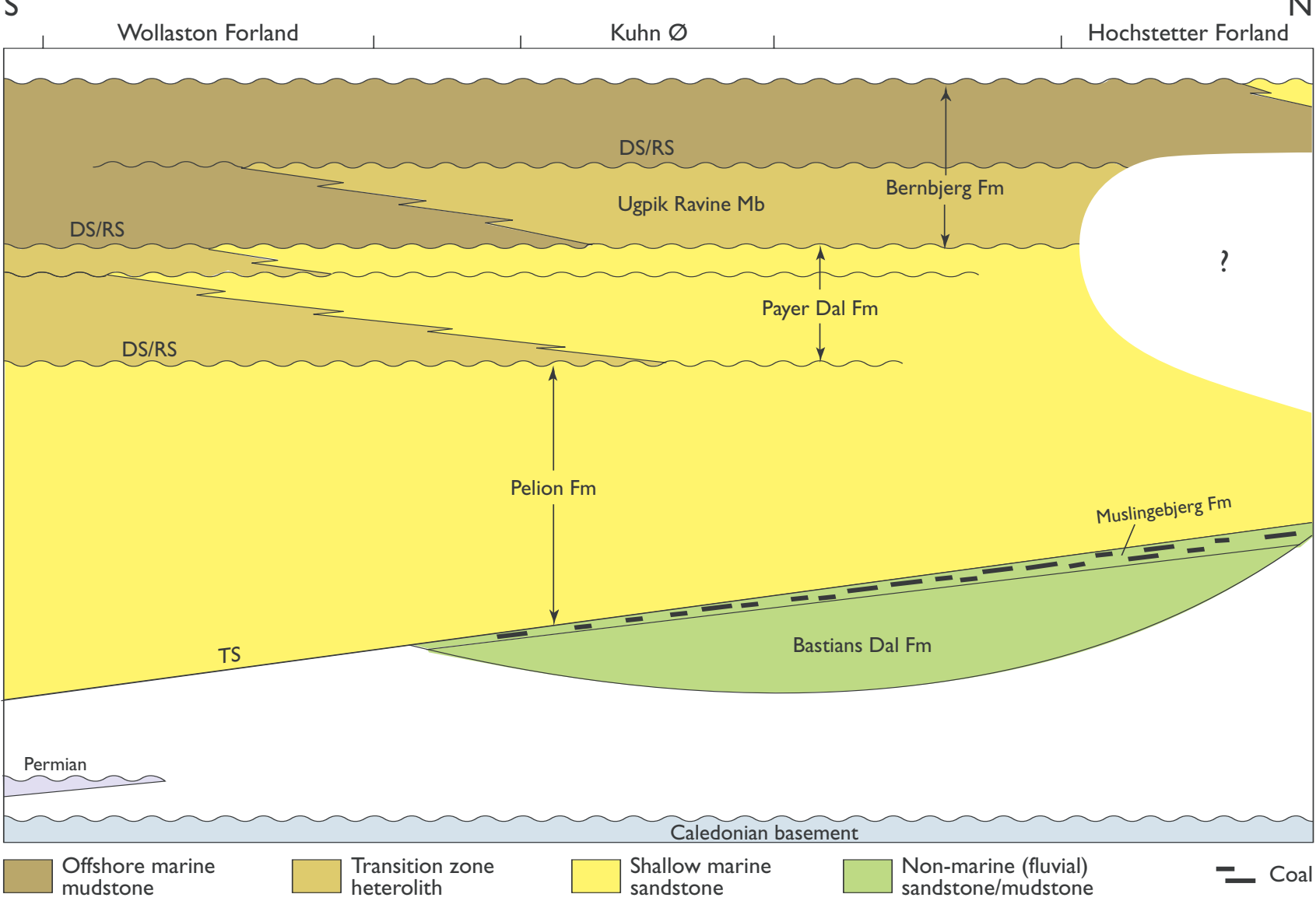

Fig. 31. Schematic S-N axial section showing the stepwise backstepping of the Middle-Upper Jurassic succession in the Wollaston Forland area. Progressively, finer-grained progradational units are separated by extensive drowning surfaces. The formations are thus also genetic units. They commonly contain facies in their top part which are similar to those occurring more distally in the underlying unit. This illustrates the difficulties in applying simple lithostratigraphic principles. The whole succession consists proximally of stacked, amalgamated sandstone bodies and distally of clearly demarcated, stacked coarsening-upwards mudstone-heterolith-sandstone units. TS, transgressive surface; DS/RS, drowning surface/ravinement surface. Based on Alsgaard et al. (2003, this volume)

\section{J2.4. Late Oxfordian - Early Volgian: increasing rifting and marine flooding}

\section{Hareelv, upper Kap Leslie and Bernbjerg Formations}

The shelf-margin wedges of $\mathrm{J} 2.3$ form the youngest preserved deposits in central Jameson Land (Olympen Formation; Fig. 29). Younger deposits of J2.4 exposed in southern Jameson Land only include slope, base-ofslope and basin-plain deposits (Fig. 32). They comprise black mudstones with large bodies of massive sandstones (Hareelv Formation; Figs 32, 33). The sandstones were transported by sediment gravity flows ranging from sandy debris flows to high-density turbidity currents. Deposition took place on the slope, base-of-slope and basin floor. Some sands were deposited in steep-walled slope gullies, whereas others were loaded into the black slope and basinal muds. The sands were strongly modified by post-burial liquefaction and intrusion into the surrounding mudstones forming a spectacular largescale intrusive complex with extremely irregular sandstone lenses, dykes and sills (Figs 33, 34, 35; Surlyk 1987; Surlyk \& Noe-Nygaard 1998, 2001a, 2001b). Remobilisation and intrusion of sand were probably triggered by earthquakes associated with increased rifting. The Upper Oxfordian part of the succession has roughly equal amounts of mudstone and sandstone, whereas the Kimmeridgian part is dominated by massive sandstones. Otherwise, the succession is completely chaotic and shows no vertical or lateral trends. Key surfaces cannot be identified, and a sequence stratigraphic breakdown has not been possible.

A correlative and somewhat shallower water offshore shelf succession is exposed in Milne Land at the 


\section{Late Oxfordian}
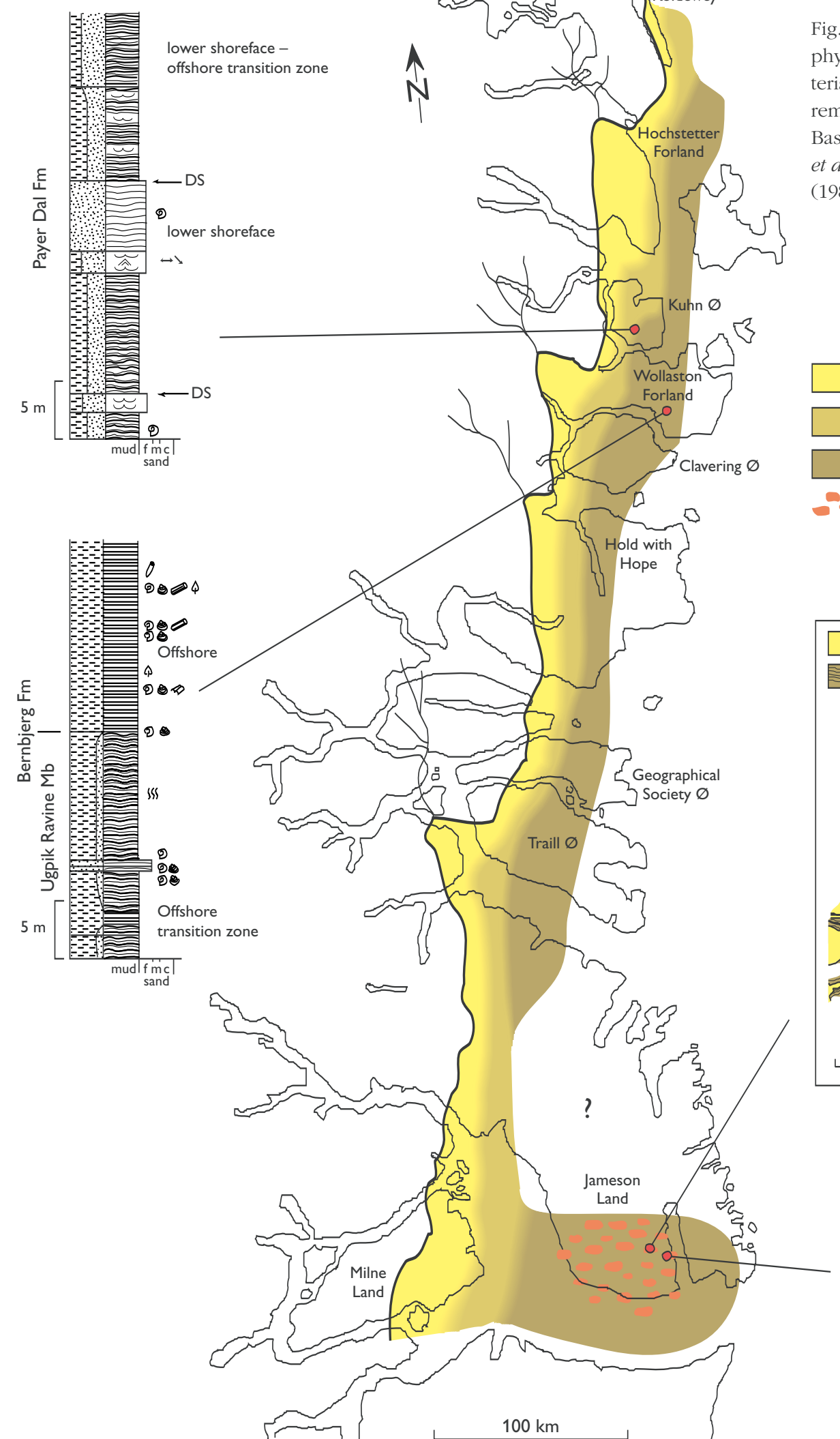

Fig. 32. Late Oxfordian palaeogeography showing sections through characteristic facies types and examples of remobilised sandstones to the right. Based on Surlyk (1977b, 1990a), Surlyk et al. (1981) and Surlyk \& Clemmensen (1983); for legend, see Fig. 6.
Shallow marine sandstone

Transition zone marine sandstone/ mudstone heterolith

Offshore marine mudstone

- Deep-water marine sandstone bodies

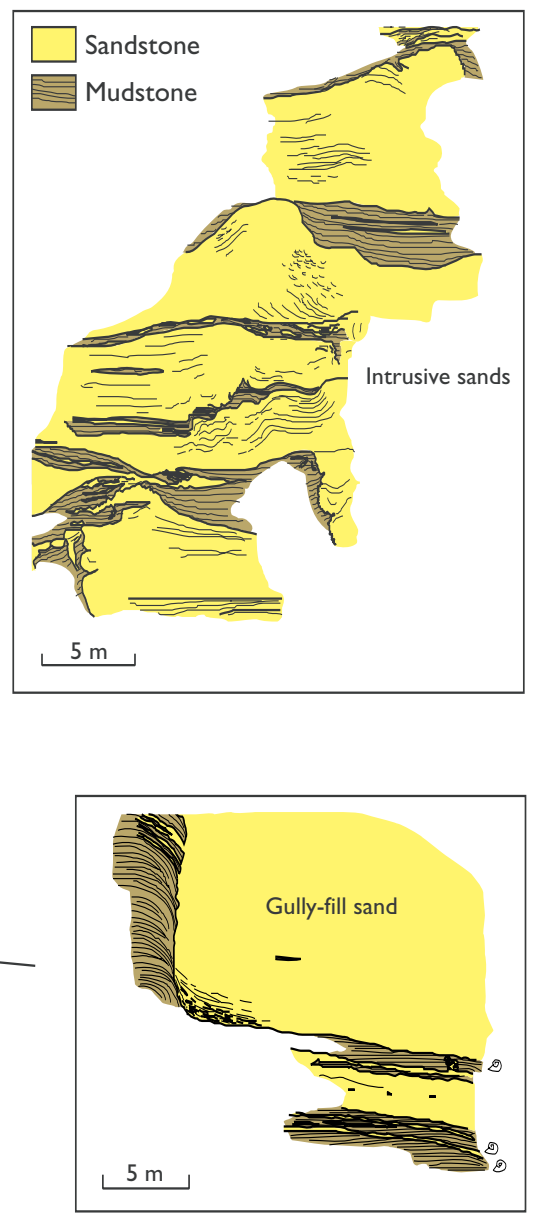




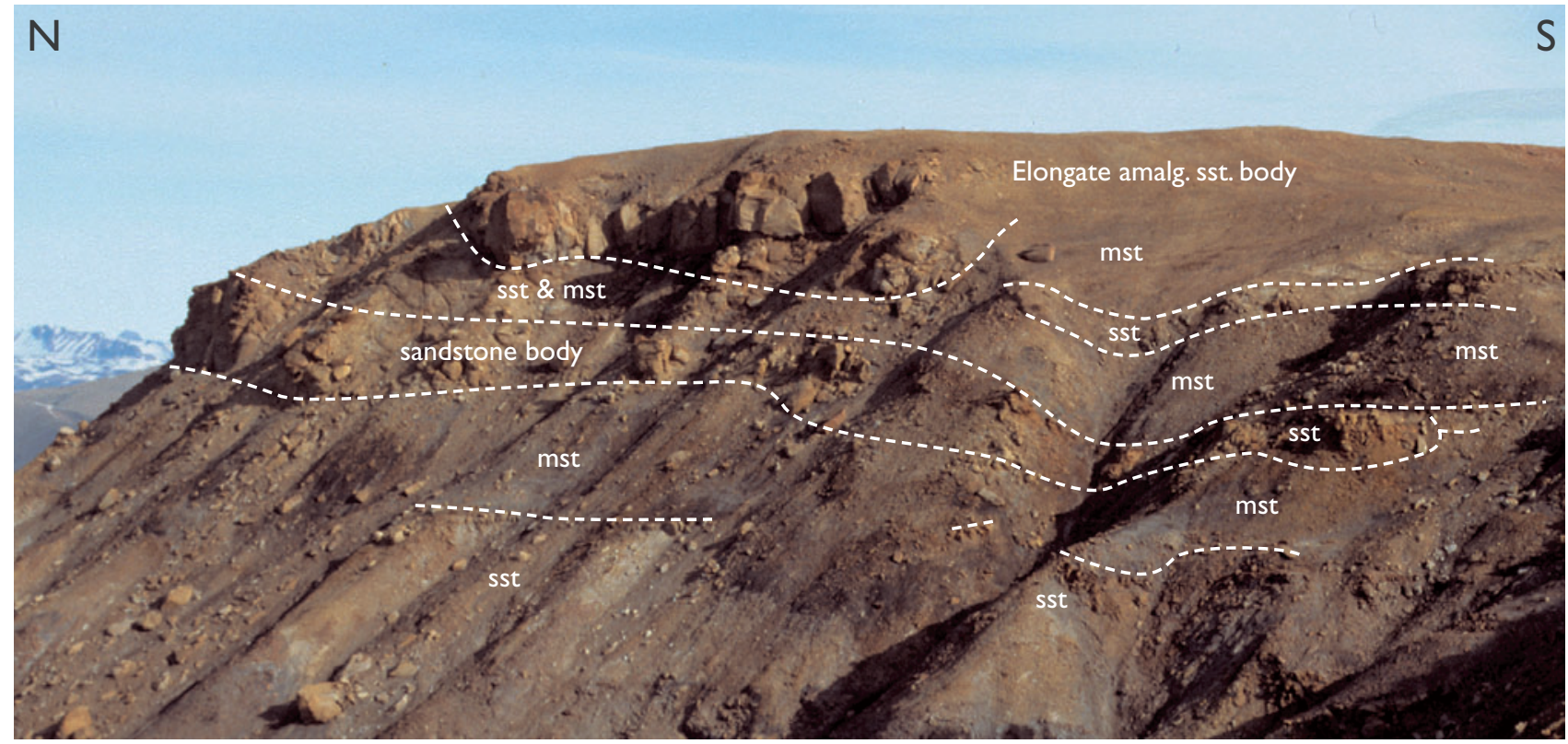

Fig. 33. Large pod-shaped sand body composed of several amalgamated massive deep-water sandstone units. The sands (sst) were liquefied post-burial and intruded into adjacent mudstones (mst). Upper Oxfordian, Hareelv Formation, south-east Jameson Land. Sandstone body seen in profile in the northern slope is about $50 \mathrm{~m}$ thick.

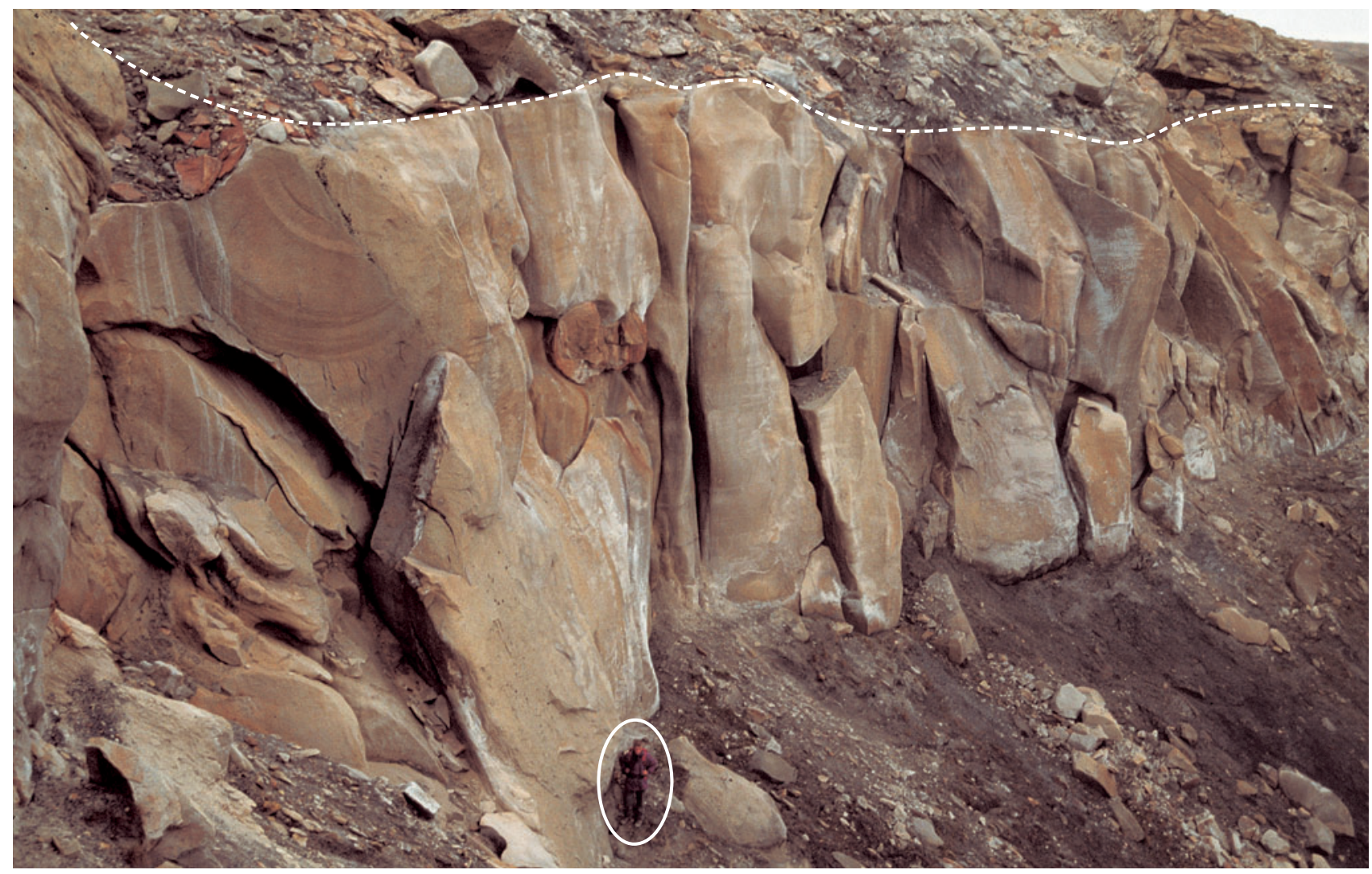

Fig. 34. Sheet-like massive sandstone representing one sedimentation unit sandwiched between black mudstones. This type of sandstone body is interpreted as having undergone relatively minor post-depositional remobilisation. It corresponds to the sandstone lobe deposit of Surlyk (1987). Eleven-year-old boy (encircled) for scale at the base of the sandstone. Hareelv Formation, south-east Jameson Land. 
western basin margin (Figs 4, 5, 32). The Late Oxfordian drowning can also be recognised in this area but was rapidly interrupted in mid Late Oxfordian time by progradation of a shelf sand body (Aldinger Elv Member of the Kap Leslie Formation, A. glosense - A. serratum Chronozones) (Figs 4, 5; Fürsich \& Heinberg 1983; Birkelund et al. 1984). It overlies thick mudstones of the Kosmocerasdal Member (Lower Callovian - Upper Oxfordian, S. calloviense - A. glosense Chronozones) to the east in a seawards direction, but wedges out in a landwards direction. The base of the coarsening-upwards sand body is a possible regressive surface of erosion formed during falling sea level. The top is a marine transgressive surface of erosion formed during renewed sea-level rise in the Late Oxfordian (A. regulare Chron). The richly fossiliferous sandstones of the Aldinger Elv Member were originally interpreted as representing an offshore bar (Fürsich \& Heinberg 1983). This interpretation is difficult to uphold because of the basinally-isolated position of the sand body which is encased in offshore mudstone. It is here interpreted as representing a shelf-margin wedge formed during a short interval of rapid sea-level fall followed by rapid transgressive drowning and associated erosion.

The Aldinger Elv Member is overlain by a coarsening-upwards succession of siltstones and glauconitic, fine-grained sandstones belonging to the Upper Oxfordian - lowermost Kimmeridgian Bays Elv Member (A. regulare- P. baylei Chronozones; Figs 4, 5). This is followed by offshore siltstones of the Lower Kimmeridgian Cardioceraskløft Member (R. cymodoce - A. mutabilis Chronozones) and black, laminated mudstones of the Kimmeridgian - Lower Volgian Gråkløft Member (A. eudoxus - A. autissiodorensis - P. elegans Chronozones) marking maximum Late Jurassic transgression (Fig. 36; Birkelund et al. 1984). The Upper Oxfordian - Kimmeridgian succession comprising the Aldinger Elv, Bays Elv, Cardioceraskløft and Gråkløft Members shows a strongly backstepping stacking pattern. A similar pattern can be recognised everywhere in East Greenland and represents the end of the transgressive part of the Middle-Late Jurassic regressive-transgressive-regressive megacycle in the Jameson Land Milne Land area (Fig. 4).

Maximum flooding persisted to the end of the earliest Volgian (P. elegans Chron), interrupted by minor regression in the latest Kimmeridgian (probably A. autissiodorensis Chron). The time interval was characterised by deposition of black, laminated, organic-rich mudstones of the Gråkløft Member, and represents the high-

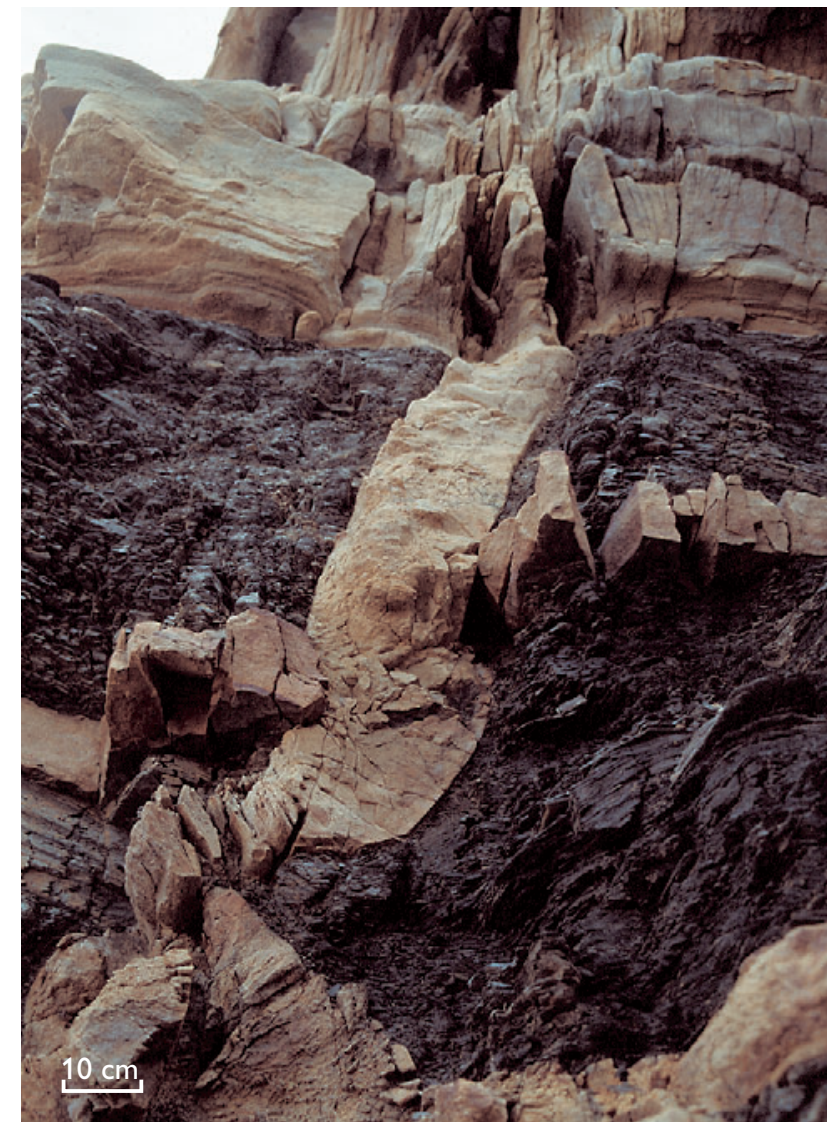

Fig. 35. Sandstone dykes and sills in black shale. Note cross-cutting relationships indicating several intrusive events. The youngest subvertical dyke is folded due to compaction of the shales. Hareelv Formation, south-east Jameson Land.

est relative sea level in the Jurassic of the Jameson Land - Milne Land area (Fig. 4).

Correlative deposits represented by the black mudstones of the Upper Oxfordian - Kimmeridgian Bernbjerg Formation are poorly preserved in the Traill $\varnothing$ region, where they subcrop strongly erosional mid-Cretaceous unconformities. Late Jurassic backstepping continued in the Wollaston Forland region, and marked drowning surfaces separate the progressively finer-grained and deeper water units (Figs 30, 31). The maximum flooding interval comprising the Upper Kimmeridgian - lowermost Volgian A. eudoxus - P. elegans Chronozones is thickly developed and consists of black laminated mudstones.

Sequence stratigraphic interpretation is hampered by the offshore mudstone-dominated nature of the succession. This problem has also been noted in studies of the Kimmeridgian of Northwest Europe (Wignall 
Kimmeridgian

Fig. 36. Kimmeridgian palaeogeography with sections through characteristic facies types. Based on Surlyk (1977b, 1990a), Surlyk et al. (1981) and Surlyk \& Clemmensen (1983); for legend, see Fig. 6.

Transition zone marine sandstone/ mudstone heterolith

Offshore marine mudstone

Deep-water marine sandstone bodies

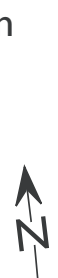

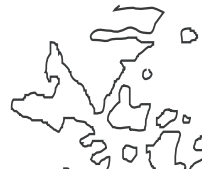

$\circ$

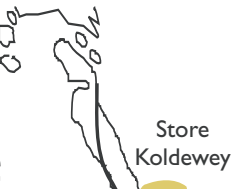

\section{N}

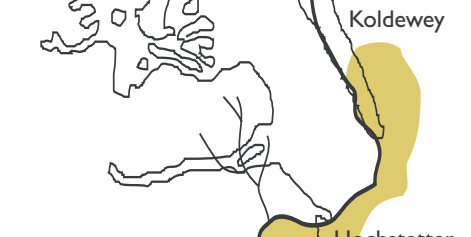
西

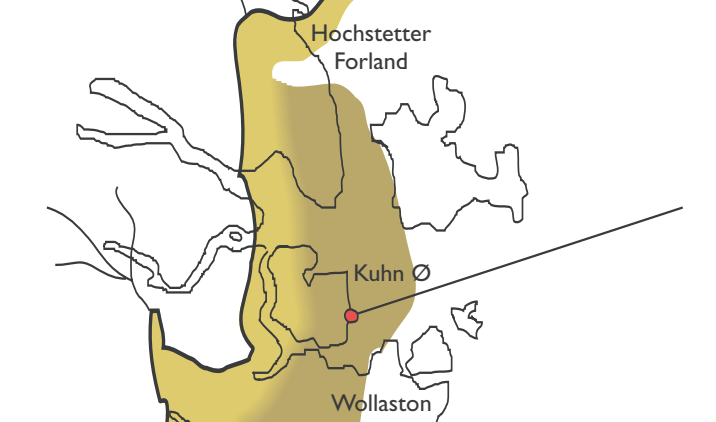

.

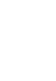


1991; Hallam 1997; Taylor et al. 2001). The dominant vertical motif is a coarsening-upwards unit topped by a drowning surface, which may or may not be erosional (Figs 31, 32). The cycles thus represent parasequences or distal sequences.

Farthest to the north, on Store Koldewey, crystalline basement is onlapped by Upper Oxfordian - Lower Kimmeridgian sandstones of the Payer Dal Formation (A. serratum, A. rosenkrantzi and A. mutabilis Chronozones) overlain by Lower Kimmeridgian mudstones of the Bernbjerg Formation (A. mutabilis Chronozone; Piasecki et al. in press).

\section{J2.5. Middle Volgian - Late Ryazanian: rift culmination, rapid progradation in the south, block tilting and gravity flow deposition in the north}

\section{Raukelv and Lindemans Bugt Formations}

Rapid, large-scale progradation characterised the end of the Jurassic period in the Jameson Land area (Fig. 37). The succession in Milne Land at the western basin margin allows a precise dating of the onset of relative sea-level fall to the Early Volgian P. wheatleyensis Chron. The black mudstones representing maximum flooding within the J2.5 sequence (Gråkløft Member) are sharply overlain by a succession of fine-grained, muddy, coarsening-upwards sandstones of late Early - Middle Volgian age (Krebsedal and Parnaryggen Members; Figs 4, 5). The base may represent sea-level fall and associated forced regression. The succession becomes glauconitic at the top, and coarse-grained sandstones occur at several levels. It is capped by a sharp drowning surface of Middle Volgian C. anguinus Chron age.

Drowning was followed by progradation of coarsegrained, coarsening-upwards sandstone units of Middle Volgian age, separated by drowning surfaces. In Milne Land, the sandstone beds are placed in the lower Hennigryggen Member of the Hartz Fjeld Formation (Fig. 38). They are fine- to medium-grained, well-sorted, show high-angle clinoform bedding and contain abundant marine trace fossils and large plant fragments. At the top there is a major hiatus between sandstones of the Middle Volgian L. groenlandicus Chronozone (lower Hennigryggen Member) and Lower(?) Valanginian, Tolliabearing sandstones (upper Hennigryggen Member).

Volgian deposits are extremely well-exposed and thickly developed in southern Jameson Land, where they form a forestepping stack of coarse-grained, peb- bly sandstone units constituting the Raukelv Formation (Figs 4, 5, 39-43; Surlyk \& Noe-Nygaard 1991, 1995). Six major progradational units are recognised in the formation, representing falling stage, lowstand or lowstand wedge systems tracts. They are separated by thin transgressive sandstone sheets. The direction of progradation was mainly lateral, away from the coastline towards the east in contrast to the axial progradation shown by the Pelion and Olympen Formations. The beds show high-angle clinoforms, and are about 15-30 m thick in most of the outcrop area but may reach a thickness of up to $50 \mathrm{~m}$ towards the east in a seawards direction. In some cases, it is possible to trace the beds towards the west where they wedge out. The thickest bed shows sigmoidal clinoforms and also has the highest content of marine fossils, notably thick-shelled bivalves and ammonites (Fynselv Member). The other clinoform beds mainly show tangential clinoforms and marine body fossils are less common. The youngest clinoform bed (Rauk Plateau Member) shows the most proximal character (Fig. 39). It is very coarse-grained, lacks body fossils, and the top surface is incised by a network of channels and valleys draped by lags of medium to coarse pebbles and scattered wood fragments.

The Raukelv Formation contains abundant evidence of tidal activity, and the dominant tidal current direction was coast-parallel towards the south with a subordinate current towards the north. The tops of the clinoform beds are draped by lags of well-rounded, discoidal quartzite pebbles with diameters normally in the order of about $1 \mathrm{~cm}$. Metre-long hairpin U-burrows of Diplocraterion habichi which are characteristic of omission surfaces, descend from the sharp upper surfaces, normally in great density. Ammonites, bivalves, belemnites and crinoids are common in beds immediately overlying the omission surfaces.

The coarse-grained pebbly clinoform beds of the Raukelv Formation are interpreted as shelf-margin wedges that prograded seawards below wave base (Surlyk \& Noe-Nygaard 1991, 1995). Very similar largescale, high-angle clinoform-bedded sand bodies have recently been described from the upper Pliocene lower Pleistocene of southern Italy; Pomar \& Tropeano (2001) termed these sand bodies 'transition-slope' deposits and considered them to represent sediment avalanches swept basinwards from the shoreface and deposited below wave base.

The positions of the fluvial entry points of the angular, poorly sorted quartz sands are not known, but were probably somewhere at the western basin margin north of the present location of the shelf-margin clinoform 
Middle Volgian
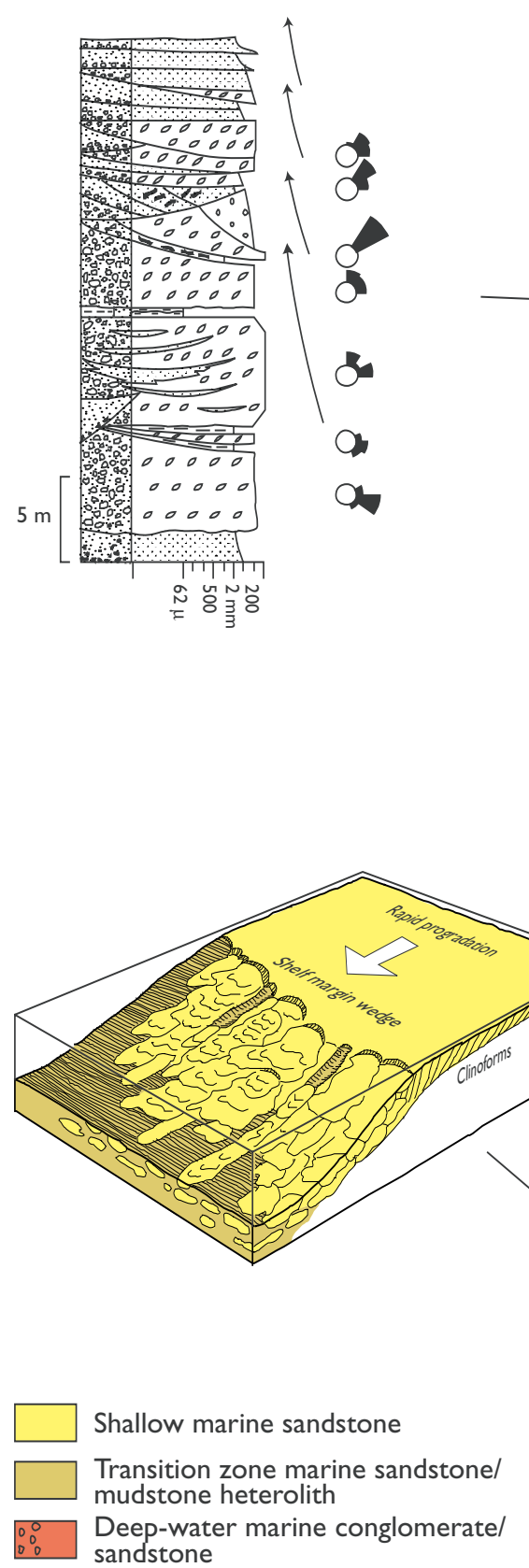

Shallow marine sandstone

Transition zone marine sandstone/ mudstone heterolith

Deep-water marine conglomerate/ sandstone
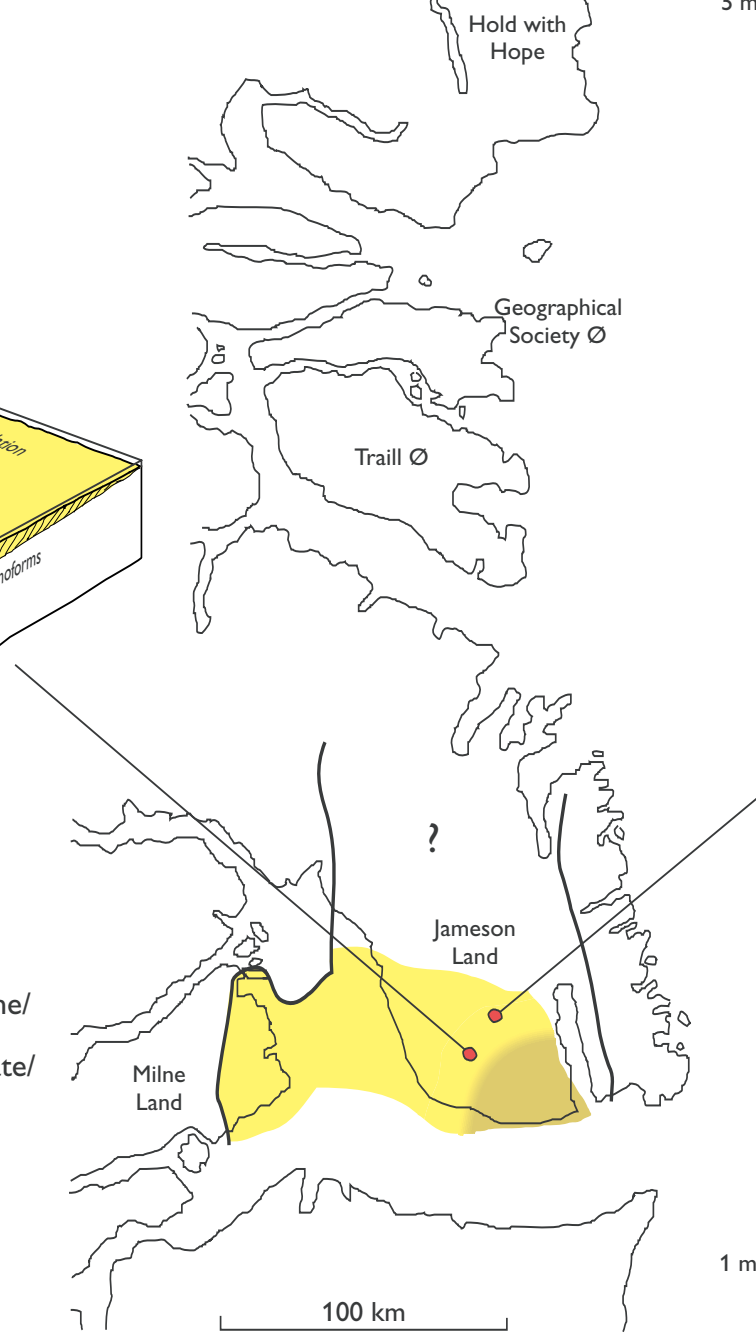

\%

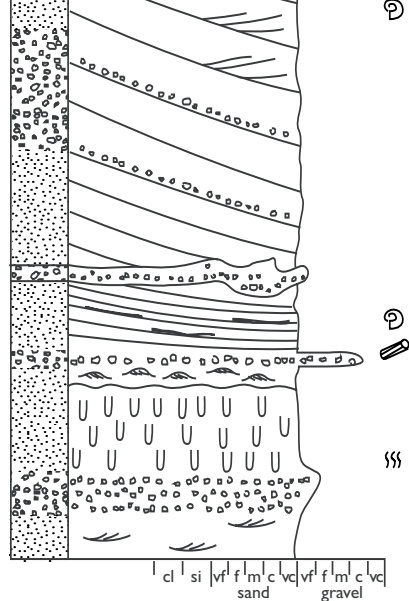

Fig. 37. Middle Volgian palaeogeography (Raukelv and Lindemansbugt Formations and correlatives) with sections through characteristic facies types and a block diagram showing the shelf-slope break in southern Jameson Land. Note the different development of the southern platform-type basin and the northern half-graben basin. Based on Surlyk (1978b, 1990a) and Surlyk et al. (1981); for legend, see Fig. 6. 


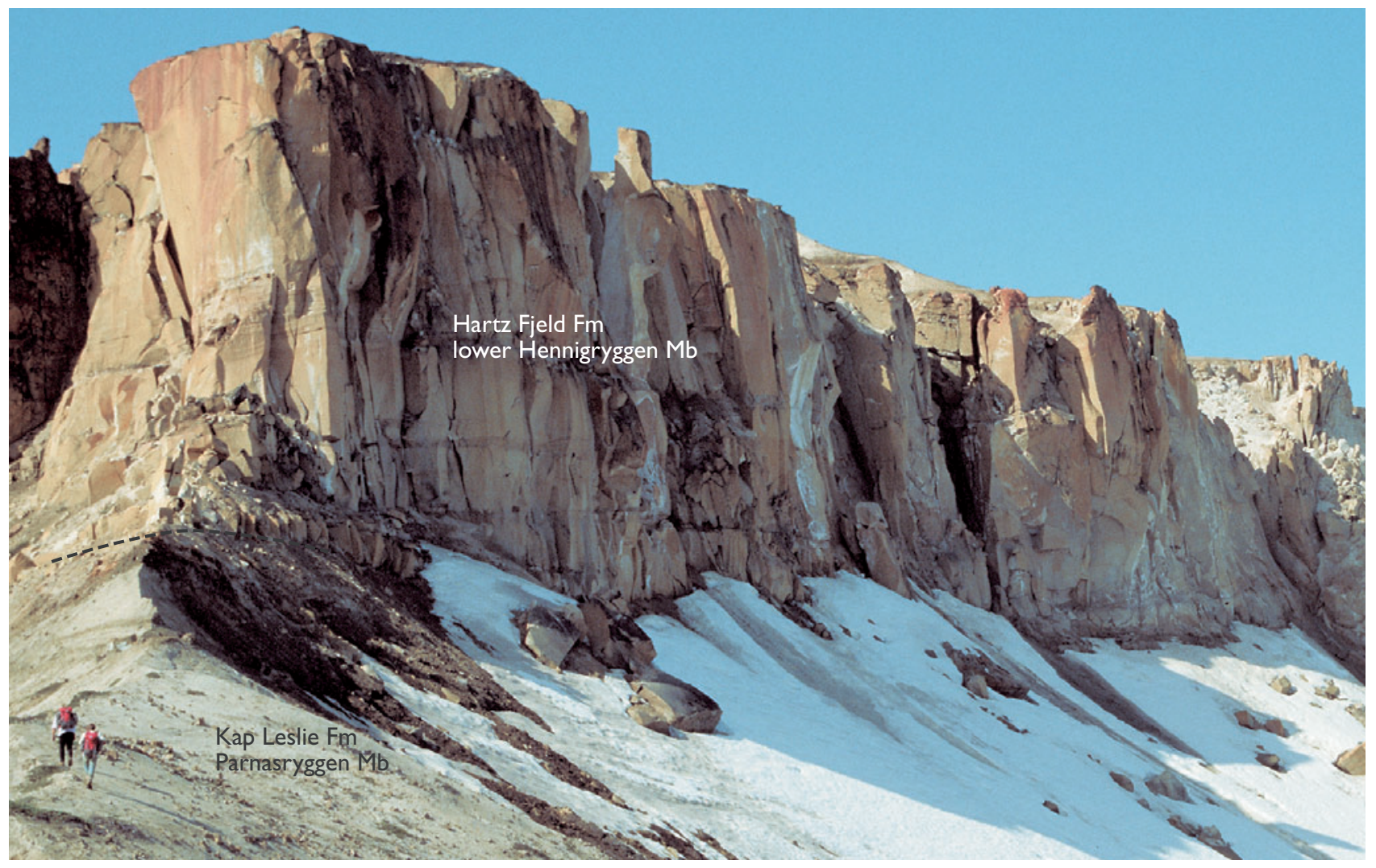

Fig. 38. Low-angle clinoform-bedded sandstone of the lower Hennigryggen Member (Middle Volgian), Hartz Fjeld Formation, Milne Land.

beds. A system of large sandwaves driven by southwards flowing coast-parallel marine currents acted as a conveyor belt, which transported the coarse-grained pebbly sand to the front of the high-angle clinoforms forming the marine-reworked delta front (Surlyk \& Noe-Nygaard 1991).

When the clinoform beds reached the shelf edge they prograded across the shelf slope break and down the upper slope where they started to collapse and the sand moved down the slope as sandy debris flows and high-density turbidity currents to be deposited on the slope and at the base-of-slope as thick massive sands forming the Sjællandselv Member of the Hareelv Formation (Figs 4, 5, 40, 41). Progradation continued, interrupted by slumping and development of debris flows, and on the upper slope all transitions between clinoform beds and massive slumped sands can be seen, whereas the base-of-slope is characterised by massive sandstones only. Further out in the basin, the massive sands are interbedded with black mudstone; this facies belongs to the youngest part of the Katedralen Member of the Hareelv Formation.
The clinoform beds are overlain by extensive sheets of glauconitic sandstone, up to $5 \mathrm{~m}$ thick, and in some cases by bioturbated highly fossiliferous mudstone. The sandstones were deposited slowly during transgression of the shelf-margin wedges. They are topped by sharp omission surfaces with great densities of Diplocraterion habichi.

The top of the Raukelv Formation (Rauk Plateau Member) is incised by a network of highly sinuous, rather steep-walled sandstone-filled channels, which lead into a major valley at the delta front (Figs 42, 43). The valley is about $10 \mathrm{~km}$ wide, up to $100 \mathrm{~m}$ deep and was probably enlarged by retrogressive slumping of the delta front. It is filled with an onlapping fully marine coarsening-upwards succession constituting the Ryazanian Hesteelv Formation, consisting of black mudstones and heteroliths (Crinoid Bjerg Member, P. maynci $-H$. kochi Chronozones) passing up into extremely fossiliferous shelly sandstones (Muslingeelv Member, $H$. kochi-?S. analogus Chronozones). Other wide, deeply incised valleys occur at the same level in the southern outcrop area. 


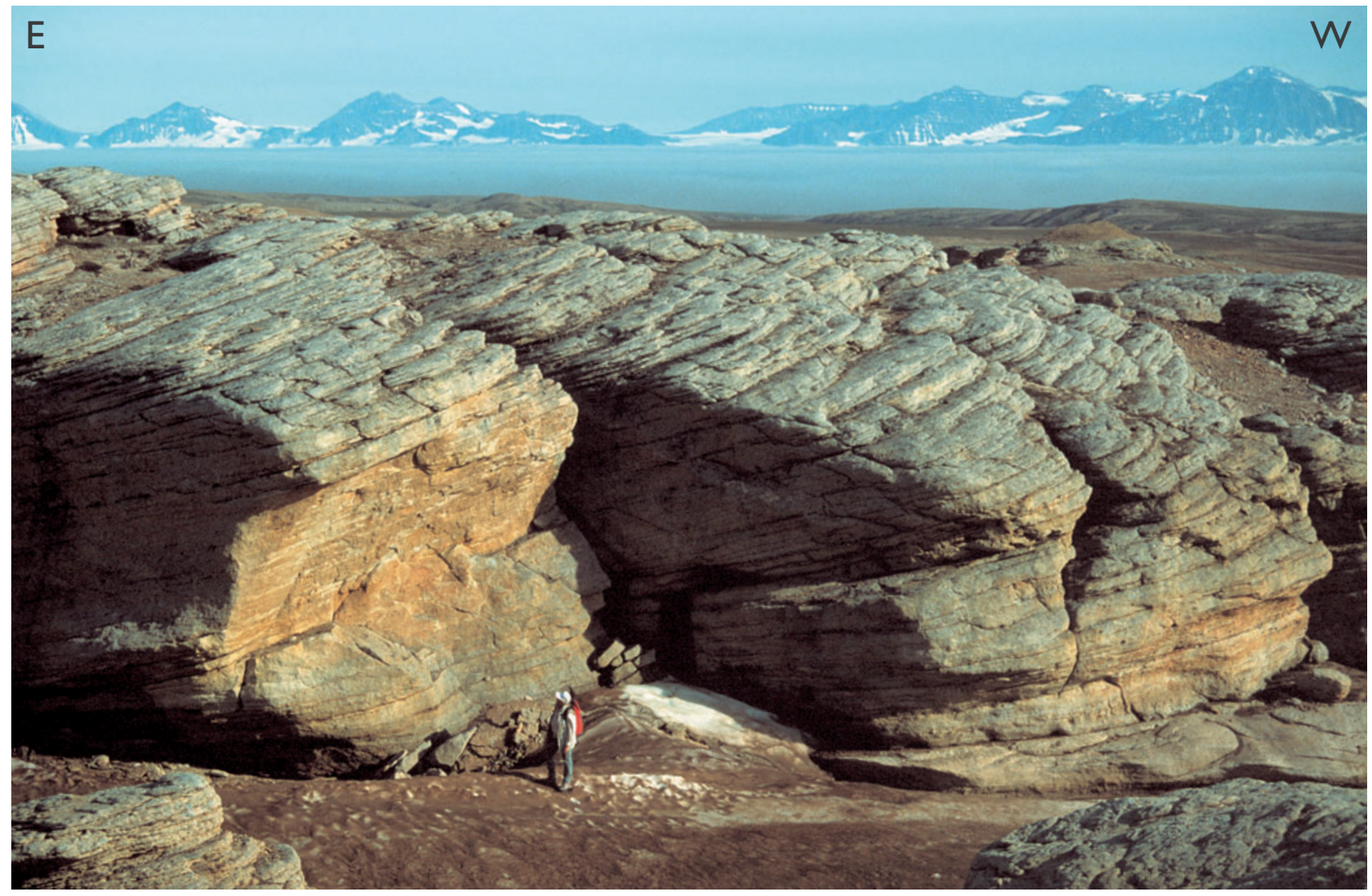

Fig. 39. Shelf-margin wedge of the upper Raukelv Formation (Rauk Plateau Member, Middle Volgian). It consists of coarse-grained pebbly sandstone showing high-angle clinoform bedding and occurs in a basinally-isolated position in south Jameson Land.

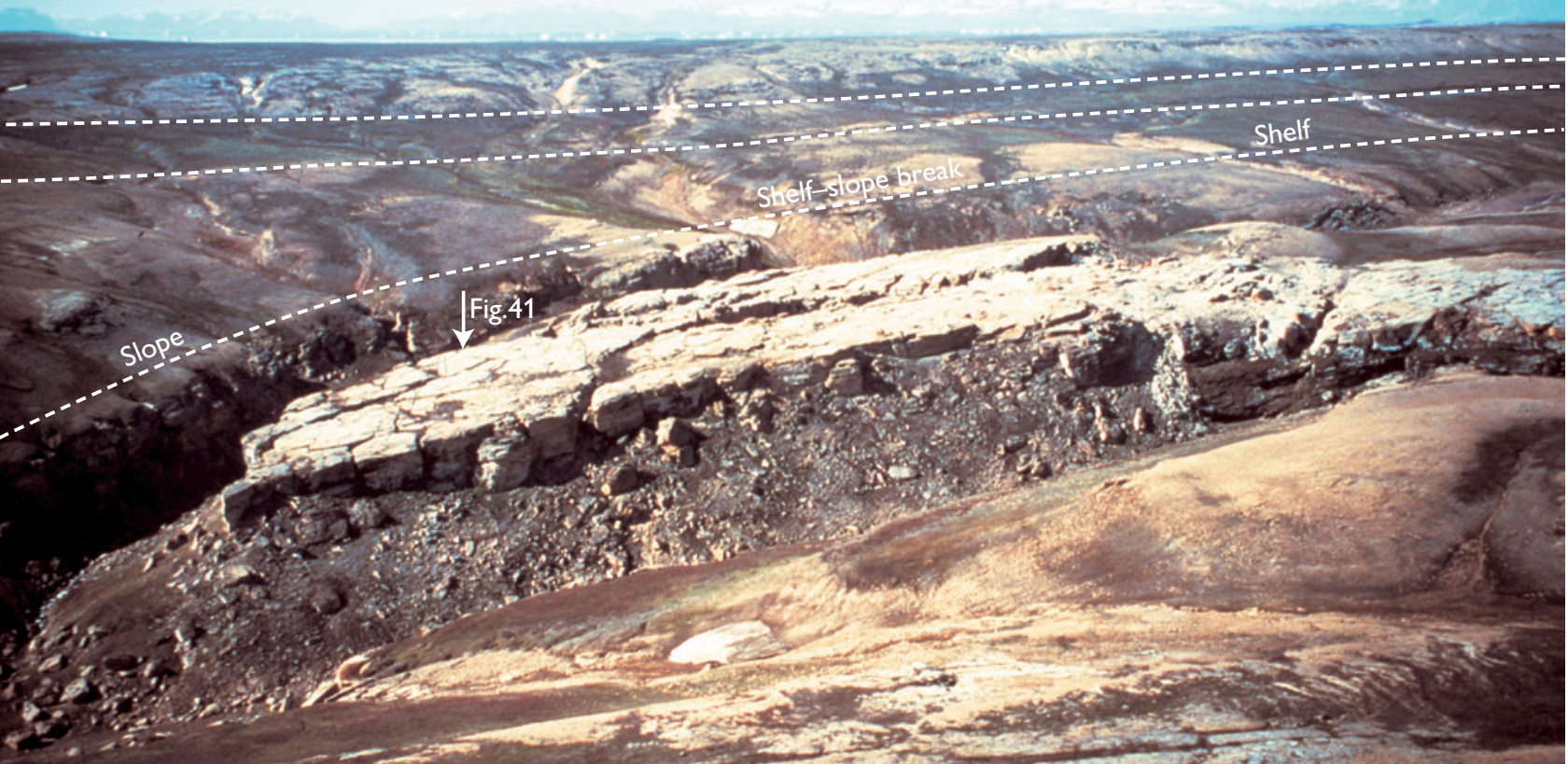

Fig. 40. Sandy shelf-margin wedge prograding across the shelf-slope break and down the slope to the left. Note the overriding nature of succeeding shelf-margin sand bodies (top of section). Regional dip 2-3 $3^{\circ}$. Inclination of slope to the left $10-20^{\circ}$. Sandstone unit about 40 m thick. Middle Volgian Fynselv Member, Raukelv Formation, southern Jameson Land. 
Fig. 41. Slump scar overlain by massive sandstone. Top of slope pictured on Fig. 40. Raukelv Formation, southern Jameson Land.

Fig. 42. Margin of highly sinuous tributary incised in Middle Volgian top of Raukelv Formation, draped with pebble veneer and filled with coarse-grained Ryazanian sandstone. Southern Jameson Land. SB, sequence boundary.

Fig. 43. Erosional unconformity at the Middle Volgian top of the Raukelv Formation formed by incision of a wide shelf-edge valley filled with marine siltstone (Crinoid Bjerg Member, Lower Ryazanian) clearly wedging out towards valley margin (to the left) and overlain by highly fossiliferous sandstone (Muslingeelv Member, Lower Ryazanian). Field of view c. $1 \mathrm{~km}$.
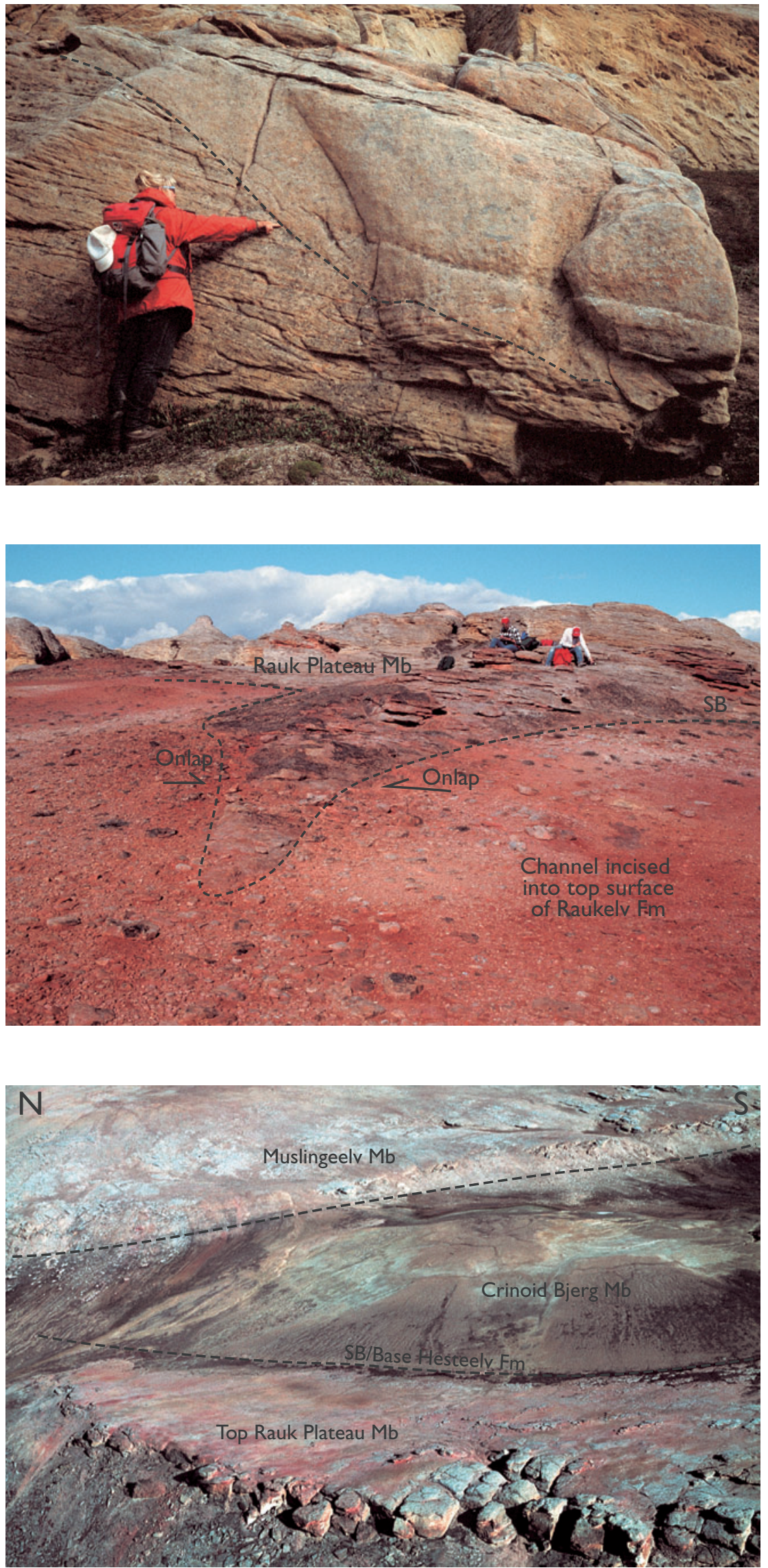


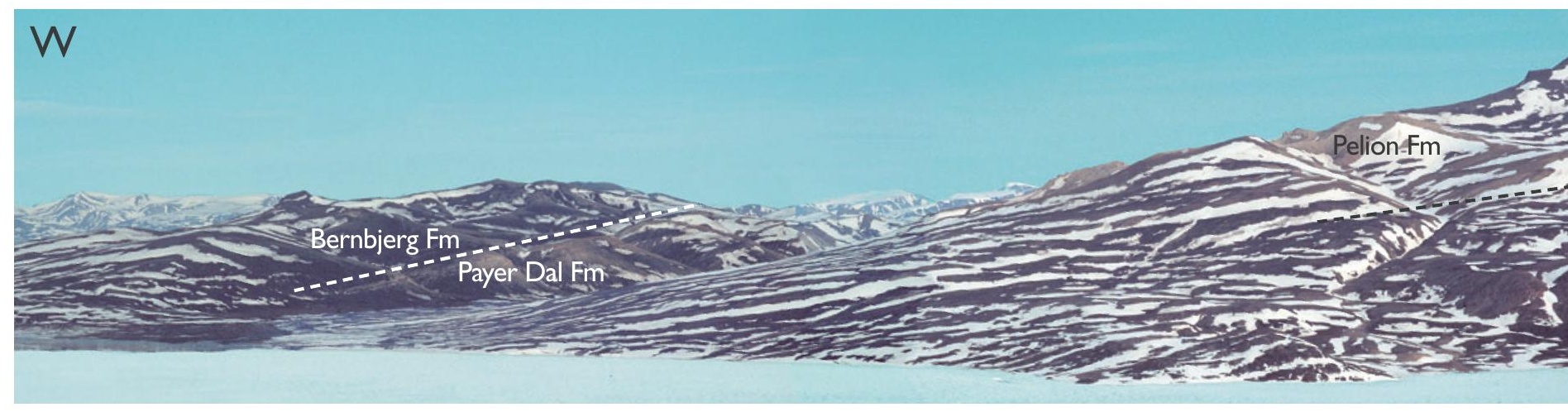

Fig. 44. Westwards tilted Jurassic fault block exposed on the south coast of Kuhn $\varnothing$. Peneplaned basement directly overlain by shallow marine sandstones of the Middle Jurassic Pelion Formation succeeded by the backstepping Middle-Upper Jurassic Payer Dal and Bernbjerg Formations (see Figs 30, 31). The volcanic ridge is c. $1000 \mathrm{~m}$ high.

The lower Hennigryggen Member (Middle Volgian) at the western basin margin in Milne Land is generally finer grained and has a higher diversity and density of marine trace fossils than the Raukelv Formation in the basin centre. The former is interpreted as highstand deposits, while the latter was deposited during a succession of major sea-level falls when coastal regres- sions reached the shelf-slope break close to the axis of the basin. There is thus a spatial separation between early highstand deposits and the associated late highstand-lowstand deposits in the order of $100 \mathrm{~km}$. Thin, widespread sheets of transgressive sandstones and mudstones drape the regressive shelf-edge sand bodies and probably extend further in a landwards direction.

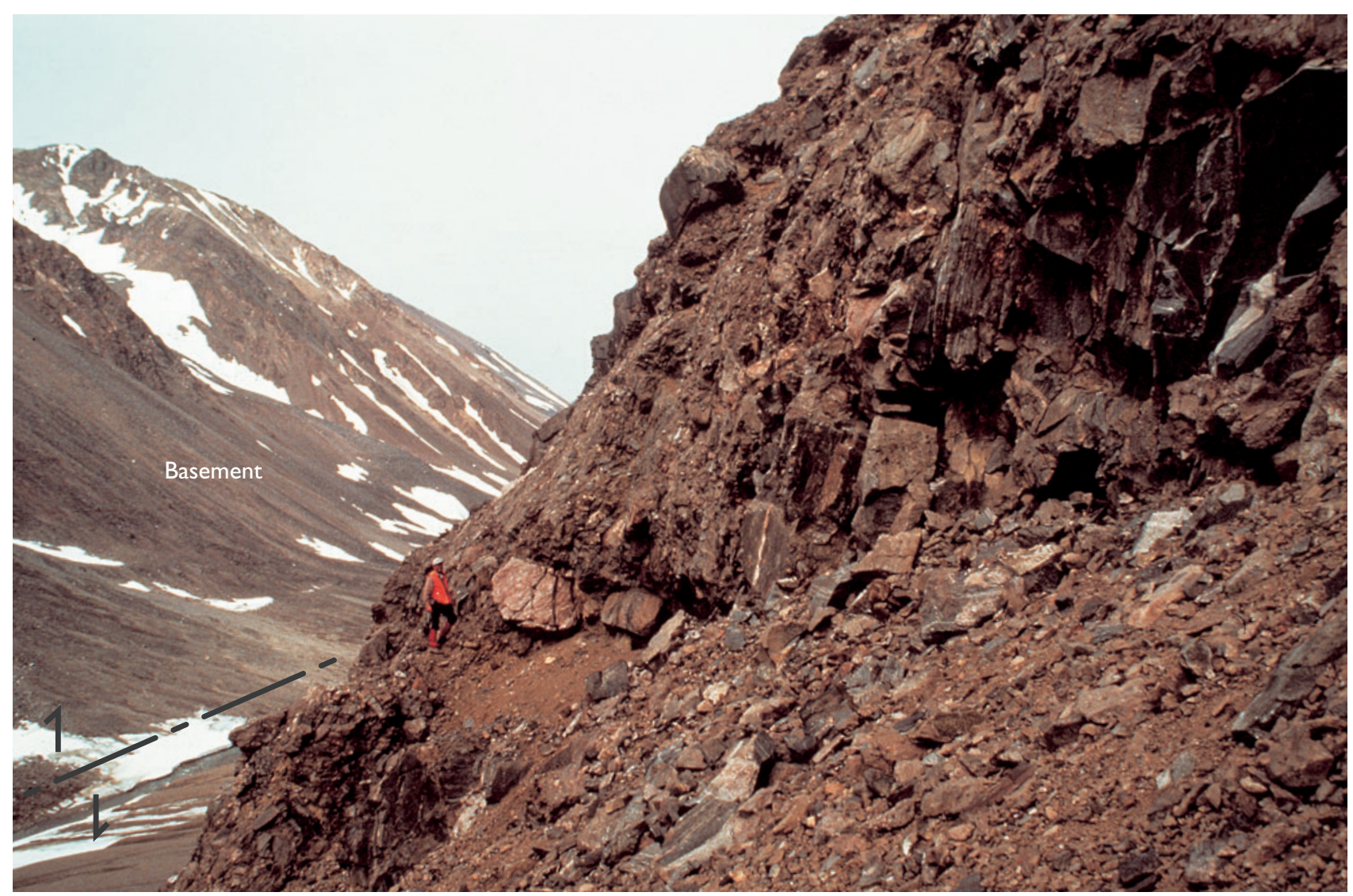

Fig. 45. Coarse conglomerates and breccias of the Middle Volgian Rigi Member (Lindemans Bugt Formation), Wollaston Forland, deposited on a fault scarp talus apron immediately adjacent to the Dombjerg Fault, western Wollaston Forland (Fig. 2). View towards the north. 


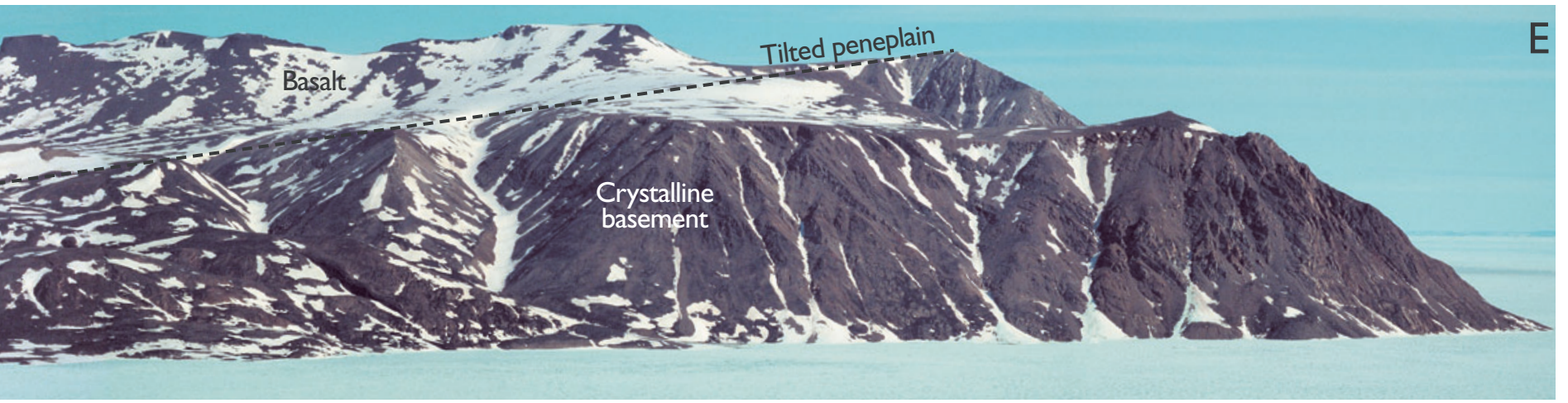

Correlative deposits are not known from the Traill $\varnothing$ region but are well exposed in the Wollaston Forland area where they form the deep-water, conglomeratedominated Wollaston Forland Group. This region underwent major rotational block faulting in the Middle Volgian resulting in the formation of deep-water halfgrabens (Figs 3, 44). They were filled mainly by conglomerates, pebbly sandstones, sandstones and subordinate mudstones deposited by a variety of sediment gravity flows (Figs 45, 46, 47; Surlyk 1978b, 1984, 1989). The group is up to about $3 \mathrm{~km}$ thick in the deepest part of the hanging wall, adjacent to the main fault scarp, and decreases to $5-10 \mathrm{~m}$ over much of the eastern block crest. The dominant motif is a fining-upwards cycle, tens to some hundreds of metres thick, thought to reflect a major fault episode and associated deepening (Fig. 47; Surlyk 1978b). The cycles may correspond to the contemporaneous shallow marine sequences of the Raukelv Formation in Jameson Land. The group is subdivided into the Volgian - Upper Ryazanian Lindemans Bugt Formation, which is dominated by boulder conglomerates, and the finer-grained uppermost Ryazanian - Hauterivian Palnatokes Bjerg Formation.

Deposition began with the formation of submarine talus breccias dominated by metre-sized blocks and rapid progradation of interbedded pebbly sandstones, sandstones and mudstones (Laugeites Ravine Member). A temporal succession of environments developed ranging from submarine talus cones, through slope aprons to coalescent fan deltas - submarine fans (Rigi Member; Surlyk 1989). The coarse-grained part of the system extends up to $25 \mathrm{~km}$ eastwards, away from the fault scarp, where it passes rapidly into black sandy mudstones (Niesen Member) close to the axis of the basin, at which point the gravity flows were checked by the opposing west-dipping hanging-wall slope. The group shows an overall fining-upwards trend, which culminated in an important Late Ryazanian drowning event.
Fig. 46. Deep-water conglomerates deposited from sediment gravity flows in the rift-climax half-graben of the Middle Volgian Lindemands Bugt Formation, Wollaston Forland. Note clast imbrication indicating eastwards transport (arrow)

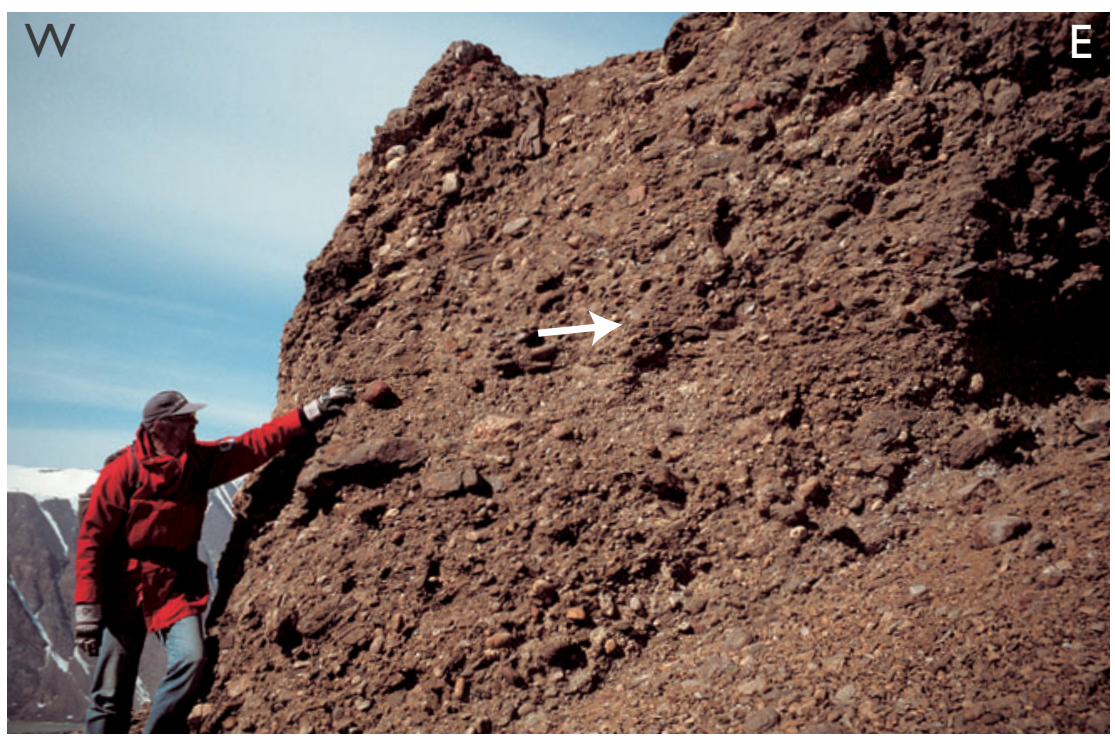



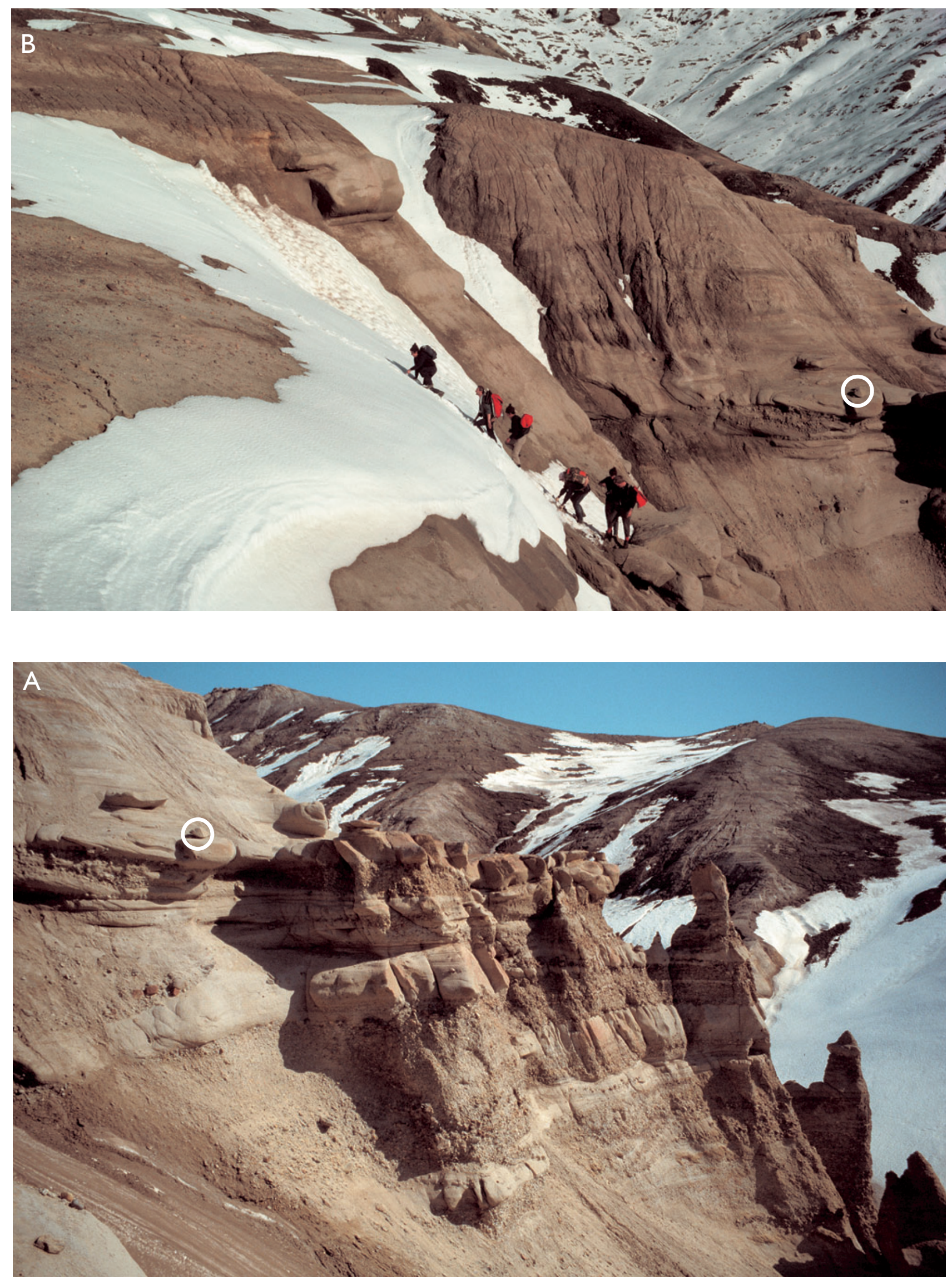


\subsection{Late Ryazanian - Hauterivian: end of rifting and regional drowning}

\section{Hesteelv and upper Hartzfjeld Formations, upper Niesen Member (Lindemans Bugt Formation) and Palnatokes Bjerg Formation}

A regional flooding event took place in the latest Ryazanian B. mesezhnikovi Chron. In southern Jameson Land, the top of the Raukelv Formation was drowned, including the fills of the distributary channel network and the valleys incised in the delta front. Massive gravity-flow sandstones directly overlie the pebbly clinoform bed of the Rauk Plateau Member, which is the youngest shelf-margin wedge of the Raukelv Formation. The massive sandstones are interpreted as base-of-slope sandstones triggered from the front of latest Ryazanian - Early Valanginian shelf-margin wedges, which occupied a more landwards position compared to the Raukelv Formation clinoform beds. The youngest shelf-margin wedges, however, are not preserved owing to modern erosion, and the massive base-of-slope sandstones form the youngest pre-Quaternary deposits in Jameson Land.

After a long period of basin margin emergence and erosion, the transgression reached Milne Land in the (?)Early Valanginian, and Middle Volgian highstand delta sandstones of the lower Hennigryggen Member are overlain by similar Valanginian sandstones deposited during the regional drowning event.

In the Wollaston Forland region, block-faulting and tilting waned, and the very coarse-grained deposits of the Lindemans Bugt Formation are overlain by the finer grained Palnatokes Bjerg Formation. Deposition of proximal conglomerates, pebbly sandstones and sandstones (Young Sund Member) persisted into the latest Ryazanian - Hauterivian, but mudstones dominate. Oxygenation at the sea floor increased, and the coarse-grained deposits pass seawards into calcareous mudstones of the Albrechts Bugt Member, which overlie the dark

\section{Facing page:}

Fig. 47. Large-scale fining-upwards succession in turbiditic deep-water conglomerates and sandstones of the Middle Volgian Rigi Member (Lindemans Bugt Formation), Wollaston Forland. Palaeotransport was towards the east, into the photographs. A: Lower conglomerate-dominated part of the section. B: Succeeding sandstone-dominated part. The encircled sandstone block is common to both photographs. grey Niesen Member mudstones. The submerged crests of blocks became draped with claret-coloured, highly fossiliferous, bioturbated mudstones of the ValanginianHauterivian Rødryggen Member (Figs 48, 49).

The coarse-grained gravity flow deposits of the Lindemans Bugt Formation were mainly transported downslope due eastwards, directly away from the fault scarps. With time, a more mature drainage and transport system developed. A transfer zone between two right-stepping border-fault segments between Wollaston Forland and Th. Thomsen Land became an important entry point for coarse clastics, and the main transport became axial towards the south (Young Sund Member).

\section{Source areas and drainage patterns}

The main source area for the Jurassic sedimentary basin complex was the Greenland craton consisting of Precambrian and Caledonian metamorphic and intrusive rocks and thick Proterozoic sedimentary successions of the Hagen Fjord and Eleonore Bay Groups, which are exposed along the eastern margin of the craton.

The crystalline basement of the Liverpool Land High constituted a minor source area east of the Jameson Land Basin, but became gradually onlapped in the Jurassic. Continental Devonian-Carboniferous deposits were exposed north and north-west of Jameson Land in Early Jurassic time while areas north of Jameson Land were onlapped during the Middle Jurassic. The increased Late Jurassic rifting, block faulting and tilting resulted in uplift and erosion of footwall crests, which formed additional minor source areas.

The main source terranes throughout the Jurassic were thus weathered metamorphic basement and intrusive rocks, and, less importantly, Devonian red conglomerates, sandstones and mudstones, Carboniferous sandstones and mudstones. An additional source was formed by Triassic conglomerates, sandstones and mudstones in the Early Jurassic due to uplift of the areas north of Jameson Land (Surlyk 1977a, 1978a; Surlyk et al. 1993; Johnson \& Gallagher 2000).

The drainage patterns underwent marked changes during the Jurassic. The Early Jurassic was a time of tectonic quiescence and thermal subsidence following Late Permian - Early Triassic rift events. Sedimentation was restricted to the Jameson Land platform, which was gently tilted towards the west. It was limited to the west by the N-S-trending Stauning Alper Fault, which formed the border to the Greenland craton. To the east, the platform was bordered by the peneplaned crystalline base- 


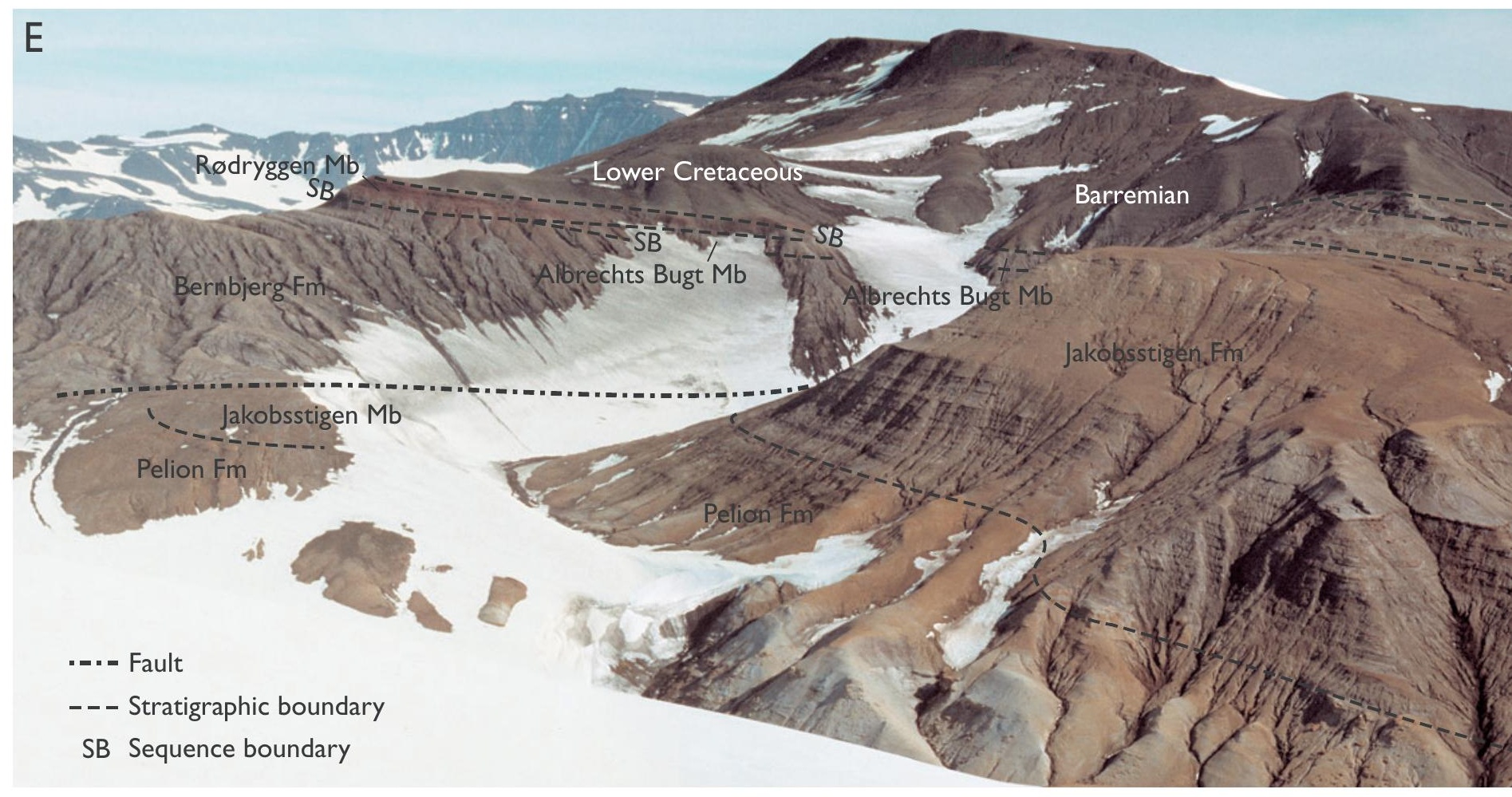

Fig. 48. Tilted Jurassic fault block, south side of the valley of Cardiocerasdal, southern Wollaston Forland. The shallow marine Middle Jurassic Pelion Formation is exposed at the base of the succession and is overlain by a backstepping succession of the Upper Jurassic Jakobsstigen and Bernbjerg Formations. This early-rift succession is faulted down to the east; to the west, it is unconformably overlain by Valanginian-(?)Hauterivian late-rift conglomerates (cgl) and sandstones (sst) of the Young Sund Member, whereas to the east on the more crestal area it is overlain by the roughly contemporaneous light grey mudstones of the Albrechts Bugt Member and red mudstones of the Rødryggen Member. The whole syn-rift succession is truncated by an irregular regional unconformity, and overlain by Lower Cretaceous (Barremian) post-rift mudstones.

ment of the Liverpool Land High, which was limited to the east by an important fault, the Liverpool Land Escarpment of Larsen (1984), and to the west by a major fault running close to the east coast of Hurry Inlet, through Klitdalen and further north through Carlsberg Fjord, where it passed into NNE- and NNW-trending splays.
The land areas bordering the Jameson Land platform were relatively low-lying with a gentle relief. The drainage was centripetal and material was transported to the basin from the west, north and east (Dam \& Surlyk 1998).

Onset of rifting in the Late Bajocian resulted in a marked change in drainage pattern. Rifting was asso-

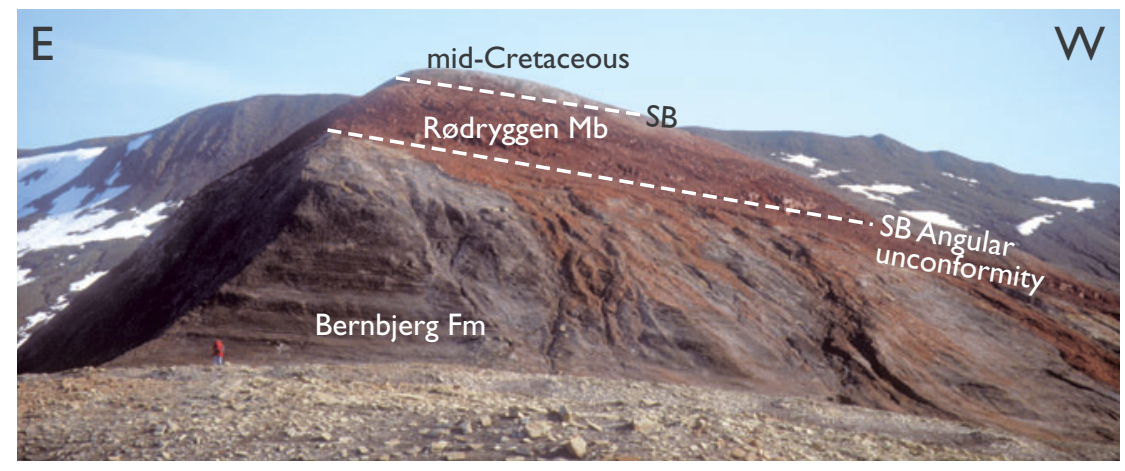

Fig. 49. Black Kimmeridgian Bernbjerg mudstones unconformably overlain by red Valanginian-Hauterivian deep-water mudstones of the Rødryggen Member, which is in turn unconformably overlain by dark-grey Barremian post-rift mudstones. Locality to the left in Fig. 48. 


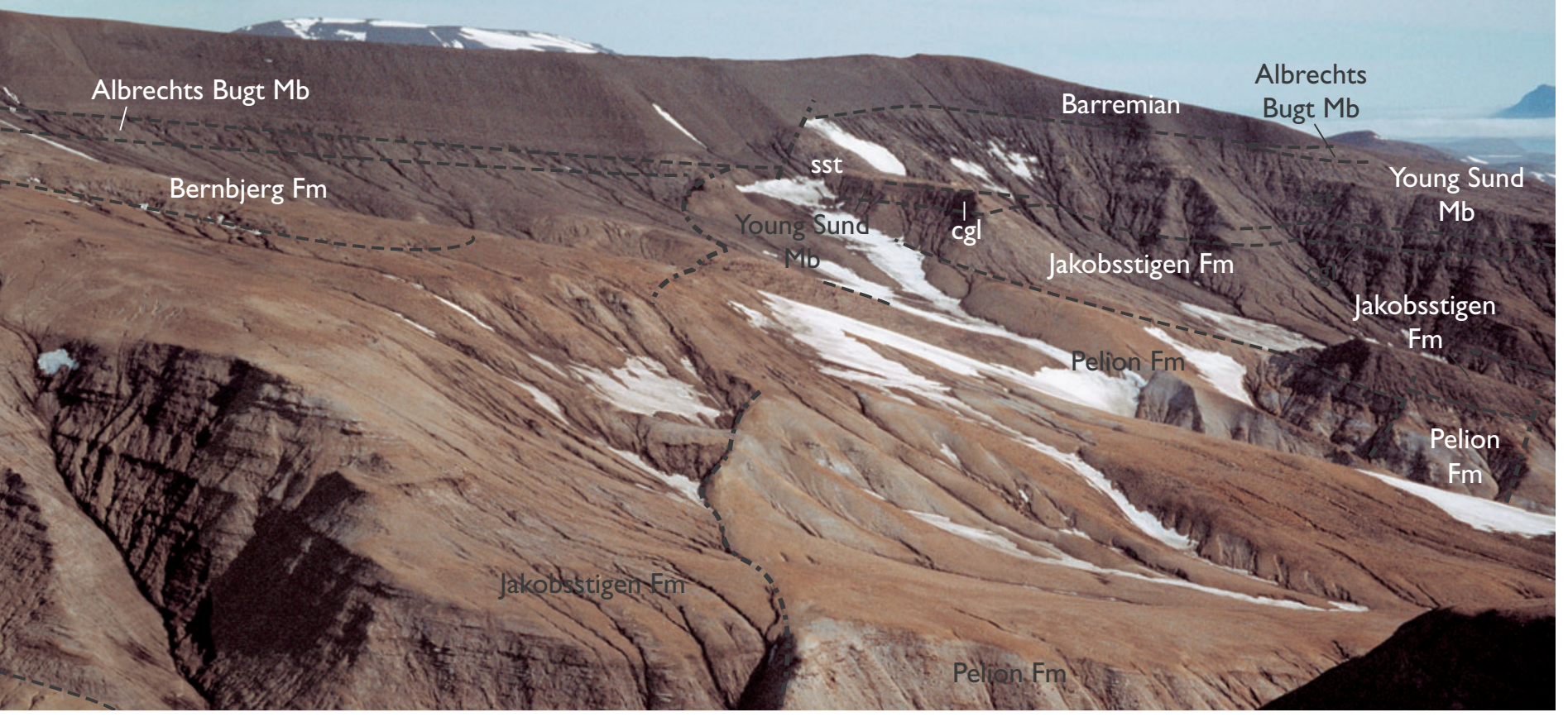

ciated with westwards tilting of fault blocks bordered by mainly N-S-trending faults. The basin was extended far north of the Jameson Land platform and two elongate embayments were formed with their heads in the Clavering $\varnothing$ and Hochstetter Forland areas. The drainage was longitudinal with the main entry points at the heads of the embayments, which can be considered tectonic estuaries. The large trunk rivers appear to have followed the tectonic grain and a major river system thus probably flowed northwards or southwards west of the depositional basin along the axes of the blocks bordered to the east by the Stauning Alper Fault - Post-Devonian Main Fault (compare Figs 2, 16 and 17). The fluvial systems could only enter the depositional basins in transfer or relay zones where the border faults side-stepped en echelon.

Sediment transport within the basin was now almost exclusively axial towards the south as reflected by palaeocurrent data, southwards grain-size decrease and facies changes. The northwards extension of the depositional basin resulted in draping of most of the Late Palaeozoic source lands and this effect was increased by late Middle - Late Jurassic eustatic sea-level rise and associated flooding of former land areas. Only the northwestern part of the Devonian basin was probably still exposed and may have acted as a source area in addi- tion to the crystalline basement rocks of the Greenland craton and the Liverpool Land High.

The increase in Late Jurassic rifting activity, in concert with sea-level rise, led to further compartmentalisation of the rift complex, and deposition became dominated by black muds and local massive sands; most of the coarser fluvial sediment load was probably trapped in estuaries. Impressive fault scarps were formed during the Volgian rift climax, especially in the Wollaston Forland region (Vischer 1943; Maync 1947, 1949; Surlyk 1978b, 1984, 1989). The scarps were sources for coarse breccias and conglomerates, deposited as transverse fault-scarp aprons and coalescent fans and axial basin floor fans (Surlyk 1978b, 1984). As rifting waned, the drainage areas enlarged and older, probably Carboniferous, conglomerates were reworked and shed into the half-graben at transfer or relay zones formed between segments of the main fault system.

The East Greenland rift complex thus witnessed longterm change in borderland topography and drainage pattern. Early Jurassic centripetal drainage of relatively low-lying borderland by numerous smaller rivers changed in Middle and Late Jurassic times into a system of major $\mathrm{N}-\mathrm{S}$-running trunk rivers with deltas at transfer or relay zones between the main $\mathrm{N}-\mathrm{S}$-trending fault zones. The provenance areas at the same time 


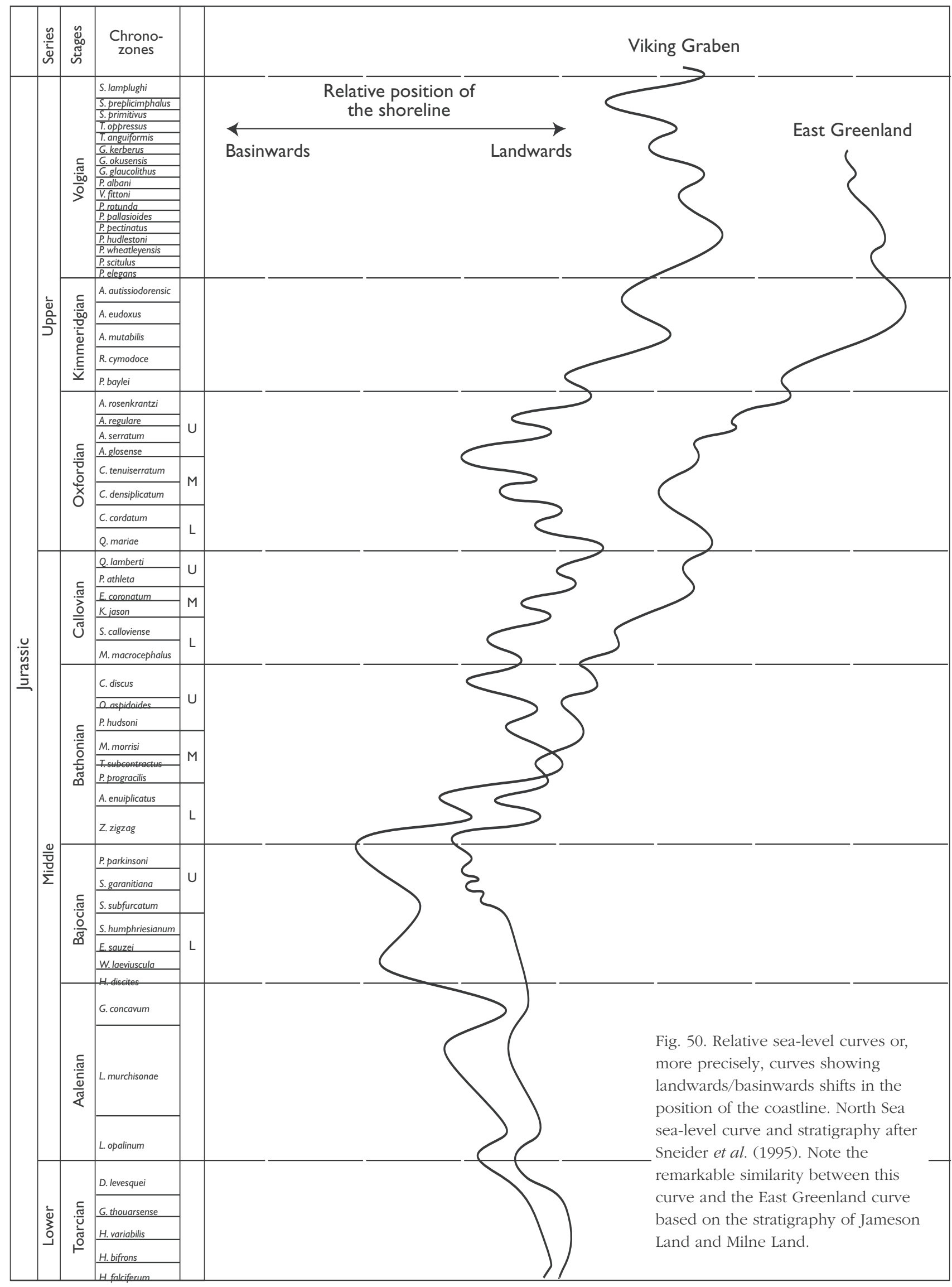


changed from basement and sediment to mainly basement-dominated.

\section{Comparison with the North Sea and adjacent areas}

Jurassic basin evolution is remarkably similar in the North Sea - North Atlantic region in an area stretching from northern East Greenland in the north to the Central Graben and the Danish Basin in the south (Figs 1, 4, $50,51)$. Major changes in facies and depositional environments occur towards the south, however, in onshore England and northern France although the Dutch North Sea sector still shows marked similarities with the regions further north (see Herngreen et al. 2003, this volume).

The uniform development of the Jurassic succession in East Greenland and the west Norway shelf is not surprising as the two areas essentially formed the western and eastern halves of the same basin complex until the onset of sea-floor spreading at the Paleocene-Eocene boundary (see Doré 1992 for an overview). Thus Stewart et al. (1995, p. 321) in their description of the Horda Platform, offshore south-west Norway, wrote "It is noteworthy, however, that the sequence architecture of similar Middle to Upper Jurassic shallow marine deposits in East Greenland is almost identical (Surlyk 1991[a]), suggesting the operation of large-scale, regional processes". A detailed comparison of the Upper Jurassic in East Greenland (based on Surlyk 1991a) and the North Sea is strongly suggestive of the isochronous nature of maximum flooding surfaces (Partington et al. $1993 \mathrm{a}, \mathrm{b})$. Most of the sequence boundaries in the Kimmeridgian - Lower Volgian of East Greenland seem to correlate well with those identified within the Kimmeridge Clay Formation in the Wessex-Weald Basin by Taylor et al. (2001). In some cases the biostratigraphic correlation is, however, not sufficiently precise mainly due to faunal provincialism. The overall evolution in the North Sea - North Atlantic region is similar in terms of tectonism and stratigraphy; there are, however, numerous smaller scale differences in timing of events and facies architecture. This may reflect real differences for example in timing of the onset and duration of major rift events and their interplay with eustatic changes in sea level, as well as the nature of source areas, drainage patterns and sediment influx. It may, however, also reflect lack of precision in biostratigraphic age determination, faunal provincialism in Middle and latest Jurassic times and use of different zonal schemes based on ammonites and dinoflagellate cysts, respec- tively. The North Sea dinocyst zonation is also less wellcorrelated with standard ammonite zones than is commonly implied by the use of ammonite zonal names for flooding surfaces that are dated exclusively by dinocysts. It is thus noteworthy that the greatest similarity with the mainly ammonite-dated sedimentological and stratigraphic evolution of East Greenland is shown by the onshore succession exposed along the Moray Firth, Scotland which is also constrained by a detailed ammonite geochronology. Precise correlation with the Norwegian shelf successions and the North Sea is more difficult. Mismatches in the age of major sequence stratigraphic key surfaces, onset of tectonism and duration of stratigraphic events may or may not be real.

The great similarity between the Jurassic of East Greenland, the North Sea and Norwegian shelf is welldemonstrated by the work of Rattey \& Hayward (1993) and Sneider et al. (1995) on the Middle-Upper Jurassic of the North Sea and Viking Graben, respectively, and by Stewart et al. (1995) on the Horda Platform (Fig. 4). Jameson Land is essentially a platform-type basin, which shows great similarity with the Horda Platform while the Wollaston Forland is a classical area for study of deepwater half-graben development and is an excellent analogue for the Viking Graben and the Moray Firth. Relative sea-level curves for the Viking Graben and Jameson Land - Milne Land are remarkably similar, even allowing for uncertainties in dating, correlation and interpretation (Fig. 50).

The Lower Jurassic is not preserved or is poorly known over much of the North Sea area due to erosion in connection with the development of the baseLate Aalenian unconformity. The Lower Jurassic of Jameson Land, East Greenland, is however an excellent analogue for the Lower Jurassic of the conjugate Norwegian margin. The remarkable similarity of the successions of the two areas allowed Dam \& Surlyk (1995, 1998) to undertake a detailed sequence stratigraphic correlation. This has been corroborated and refined recently by a sequence stratigraphic interpretation of the uppermost Ostreaelv Formation - Sortehat Formation (Hansen 1999).

The Jurassic of the Inner Moray Firth is selected for a more detailed comparison with East Greenland because both areas include outcrops and are dated mainly by ammonites (Fig. 51). The Jurassic onshore and offshore Moray Firth has recently been interpreted within a sequence stratigraphic framework (Stephen et al. 1993; Stephen \& Davies 1998) while much detail on the actual sections is compiled in an excellent field guide (Trewin \& Hurst 1993). 


\section{Comparison with the Middle-Upper Jurassic of the Moray Firth}

The Triassic-Jurassic transition was marked by alluvial deposition both in East Greenland and the Moray Firth, where the Late Rhaetian - Sinemurian successions are represented by the Kap Stewart Group and the Dunrobin Bay Formation, respectively. The tops of both units are major sequence boundaries. Marine transgression took place close to the Sinemurian-Pliensbachian boundary with maximum flooding in the lowermost Pliensbachian P. taylori Subchronozone of the U. jamesoni Chronozone in both areas (Sellwood 1972; Dam \& Surlyk 1998). Interestingly, a similar succession of events has recently been demonstrated from the island of Bornholm in the Baltic (Surlyk et al. 1995; Donovan \& Surlyk 2003, this volume). The remaining Lower Jurassic stages are not represented in the Moray Firth due to non-deposition and erosion associated with uplift of the North Sea dome and formation of the mid-Aalenian unconformity (the 'Mid-Cimmerian Unconformity' of Underhill \& Partington 1994, and many others).

The erosional topography was gradually onlapped in late Middle Jurassic time by the Brora Coal Formation. A similar development can be seen in Milne Land and in the areas further north in East Greenland (Figs 4, 25, 31) where Middle and Upper Jurassic sandstones of the Charcot Bugt, Pelion and Payer Dal Formations onlap Triassic, Upper Permian or crystalline basement (Surlyk 1977a, 1978a). There is thus abundant evidence for major pre-Middle Jurassic uplift or doming in large parts of the North Sea - North Atlantic region. The age of the terrestrial and lagoonal Brora Coal Formation is poorly constrained but it is roughly contemporaneous with the Pelion Formation and likewise represents the lower part of a long-term Middle Jurassic regressivetransgressive cycle (Fig. 51). The top of the Brora Coal Formation was deposited in a lagoonal environment followed by a short regressive interlude at the BathonianCallovian boundary represented by the Brora Coal. This regressive event is contemporaneous with a similar event in East Greenland represented by the Parnas Member at the top of the Pelion Formation, which interrupts the long-term backstepping of the Pelion-Fossilbjerget couplet (Fig. 4).

The Brora Coal Formation is overlain by the transgressive Brora Roof Bed succeeded by mudstones and shales of the Brora Shale and Brora Brick Clay with a thin intercalation of the very fine-grained Glauconitic Sandstone. This interval correlates with the Goniomyakløft Member (Fossilbjerget Formation), which repre- sents the final marine drowning of the shallow marine sandstones of the Pelion Formation. Maximum flooding took place in E. coronatum - earliest P. athleta Chron time, at the Middle-Late Callovian boundary, in both areas. Maximum flooding was followed by progradation, in the Moray Firth represented by the Upper Callovian Fascally Siltstone - Fascally Sandstone - Clynelish Quarry Sandstone package which corresponds to the equally progradational Athene Member of the Olympen Formation (Fig. 51). The latter unit is dominated by massive sandstones deposited from sediment gravity flows on the slope of a high-angle clinoform bedded shelfmargin wedge. The massive, wavy-bedded Clynelish Sandstone is clearly of similar nature, and was deposited from sediment gravity flows. This interpretation contrasts with previous interpretations, which involve tidal influence (Hurst 1993; Stephen et al. 1993; Stephen \& Davies 1998). The alternative interpretation of depositional processes and environment offered here casts some doubts on the reality of the sequence stratigraphic interpretation of Stephen et al. (1993) and Stephen \& Davies (1998). The sharp base of massive gravity flow sandstones may reflect the nature of the sedimentary processes rather than representing a regressive surface of erosion caused by sea-level fall. The base of the Clynelish Quarry Sandstone may thus be strongly diachronous reflecting repeated collapse of sand along the shelf edge and downslope transport of the triggered gravity flows (unpublished data, F. Surlyk 2002).

The Clynelish Quarry Sandstone is overlain by a thin fine-grained unit, which is a correlative of the shales of the Hades Member (Olympen Formation); it represents the drowning of the first shelf-edge delta and associated slope deposits at the Callovian-Oxfordian boundary. In the Moray Firth, the drowning interval was succeeded by renewed progradation of the Brora Sandstone Member. The member is of Early-Middle Oxfordian age but the dating is not well-constrained. The much-figured but somewhat enigmatic high-angle clinoform-bedded sandstones at Strathsteven Cliffs are referred to the Brora Sandstone Member and have mainly been interpreted as having been deposited by migrating sand dunes in a strongly tidally influenced sea (e.g. Stephen \& Davies 1998, fig. 15) or a large seawards-dipping bar structure (Sykes 1975; Hurst 1993). The clinoform beds are here interpreted to represent a shelf-margin wedge or delta due to the remarkable similarity to the shelf-margin wedge of the contemporaneous Zeus Member, Olympen Formation, and even more to the stacked Volgian shelf-margin wedges of the Raukelv Formation which also migrated seawards at a 

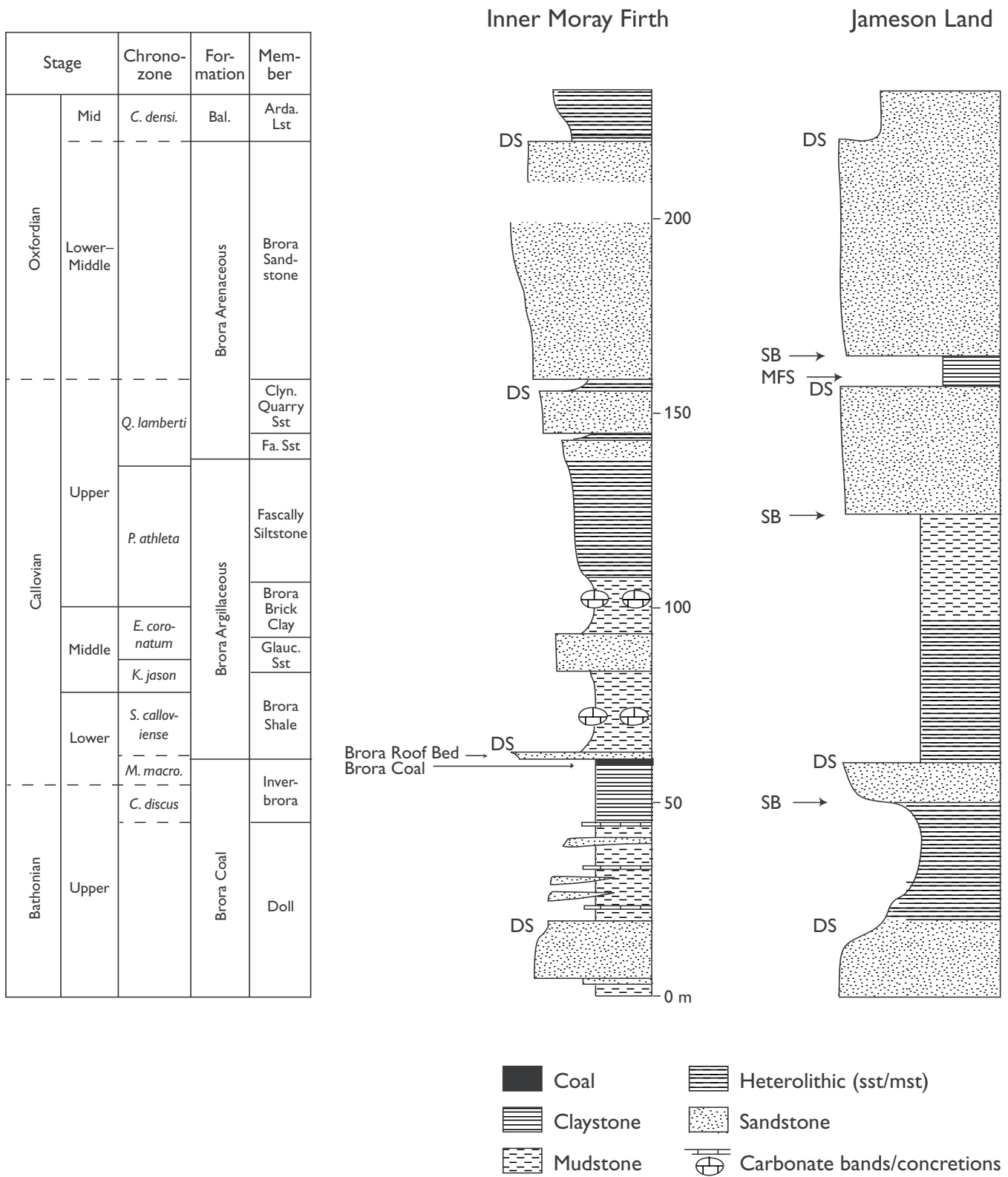

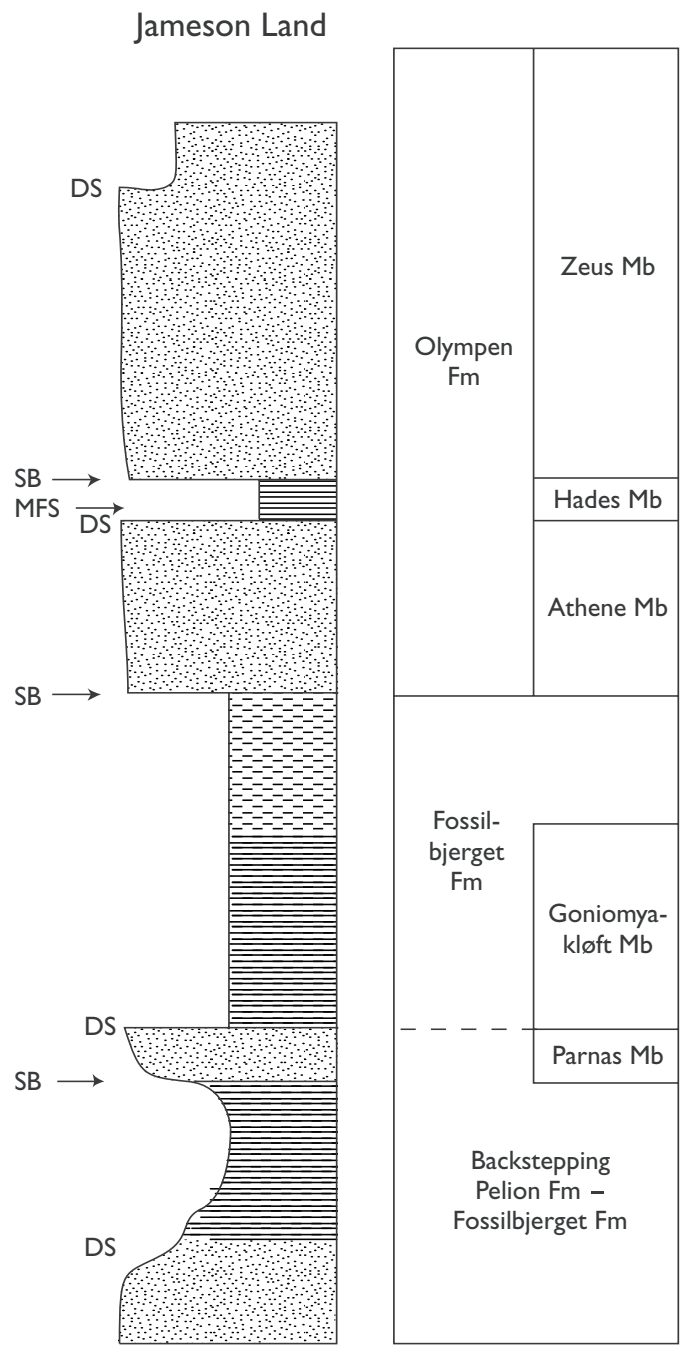

Fig. 51. Comparison of the Middle - lower Upper Jurassic stratigraphies of the Inner Moray Firth (modified from Trewin \& Hurst 1993; Stephen \& Davies 1998) and Jameson Land. Note the remarkable similarity in overall trends and age of main flooding events. The Jameson Land schematic section is not to scale, thicknesses being normalised to the Moray Firth section. C. densi., C. densiplicatum; M. macro., M. macrocephalus; Arda., Ardassie; Bal., Balintore; Clyn., Clynelish; Fa., Fascally; Glauc., Glauconitic; DS, drowning surface; MFS, maximum flooding surface; $\mathbf{S B}$, sequence boundary.

right angle to the basin-bounding fault during periods of sea-level fall. The Upper Callovian - Middle Oxfordian of both areas thus shows a highly similar development both stratigraphically and in terms of depositional processes and environments. As interpreted here, both areas show a development from a ramp to a shelf-break basin associated with forestepping Late Callovian and Early-Middle Oxfordian sandy shelf-margin wedges sep- arated by a latest Callovian - earliest Oxfordian drowning event. When the deltas reached the shelf-slope break in both areas, the delta front collapsed and sands were transported down the slope by sediment gravity flows (Surlyk \& Noe-Nygaard 2001b; Larsen \& Surlyk 2003, this volume).

The Middle Oxfordian drowning of the Brora Sandstone was accompanied by a marked change in facies 
and rapid deepening of the basin. Upper Oxfordian deposits are only known from offshore Moray Firth where they are represented by a backstepping progressively finer grained succession with peak transgression in the latest Kimmeridgian or earliest Volgian (Stephen \& Davies 1998). This is similar to the development in East Greenland where drowning of the shallow marine Olympen, Charcot Bugt and Jakobsstigen Formations was succeeded by a backstepping succession of increasingly finer grained units (Figs 4, 30, 31).

The Upper Oxfordian - Kimmeridgian interval records the onset of the main rifting phase with tilting of fault blocks and extensional half-graben development in the Moray Firth area (Underhill 1991). The coastal outcrops along the Helmsdale Fault present a variety of sediment gravity flow deposits ranging from sandstone breccias and quartz sandstones of the Allt na Cuile Formation to conglomerates and breccias of the Kintradwell and Helmsdale Boulder Beds (Pickering 1984; MacDonald \& Trewin 1993; Wignall \& Pickering 1993; Theriault \& Steel 1995). This succession is again remarkably similar in tectonic setting and facies to the thick deep-water conglomerate-dominated Wollaston Forland Group of northern East Greenland (Surlyk 1978b, 1984, 1989), as originally noted by B.W. Sellwood (in: Anderton et al. 1979). Accumulation of fault-scarp conglomerate aprons in the Moray Firth started, however, in the earliest Kimmeridgian and culminated with deposition of the Helmsdale Boulder Beds in the Late Kimmeridgian Middle Volgian. The Wollaston Forland Group is of Early or Middle Volgian to Hauterivian age with a climax of coarse-grained deposition in the Middle Volgian. The oldest rift climax deposits, the Allt na Cuile Formation, occur immediately adjacent to the scarp of the Helmsdale Fault and are represented by immature turbidites and related deposits (Wignall \& Pickering 1993; Damholt 1996). In the most distal exposures, the Allt na Cuile Formation comprises massive sandstones, which have undergone post-burial liquefaction and intrusion into the adjacent sediments (unpublished data, F. Surlyk 2002) and this part of the formation shows great similarity to the extremely well-exposed Hareelv Formation in Jameson Land, East Greenland (Surlyk 1987; Surlyk \& Noe-Nygaard 1995, 2000b, 2001b).

The Jurassic sections of the two areas thus include an Upper Rhaetian - Lower Jurassic pre-rift succession, which can be considered a late post-rift succession with respect to a major Late Permian - Early Triassic rift event. It shows an overall long-term transgressive development, which was terminated by widespread doming or regional uplift in late Early Jurassic time. Subsidence and onlap of the uplifted areas started in the Late Aalenian in the Moray Firth - North Sea region and in the Late Bajocian in East Greenland. The subsequent development records incipient rifting in the BajocianBathonian, followed by increasing rifting and progressive drowning of the sand-dominated systems in Late Bathonian - Callovian times. Maximum drowning took place close to the Middle-Late Callovian boundary with a subsequent change from a ramp to a shelf-break basin. Sandy shelf-margin wedges were formed in the Late Callovian and Early-Middle Oxfordian, separated by a drowning event at the Callovian-Oxfordian boundary.

Massive sands were shed from the delta fronts and deposited on the slope by sediment gravity flows. A major phase of basin reorganisation and facies change took place in the Late Oxfordian when the sandy shelfmargin wedges were drowned. This event records the onset of major rifting, which continued through the Kimmeridgian to culminate in the Middle Volgian. This general theme can be recognised throughout the North Sea - North Atlantic region.

The similar development of the Jurassic in the North Sea - North Atlantic region has two basic implications. One is that outcrop analogues exist in East Greenland for practically all types of offshore petroleum reservoirs and play types, allowing study of dimensions, 3-D geometry, facies changes and predictability of major reservoir types. The other is that not only the similarities but also the differences in development allow conclusions to be drawn concerning factors governing basin evolution and sedimentation.

\section{Summary and conclusions}

The Rhaetian-Hauterivian succession of East Greenland comprises two megasequences, $\mathrm{J} 1$ and $\mathrm{J} 2$, representing different tectonic regimes. The Rhaetian - Lower Bajocian $\mathrm{J} 1$ package forms a pre-rift megasequence with respect to the overlying syn-rift deposits. Genetically it is more precisely described as a post-rift package with respect to Late Permian - earliest Triassic and late Early Triassic rift events. The Upper Bajocian - Hauterivian package forms a syn-rift megasequence, formed during a protracted rift episode that began in the Late Bajocian, increased through the Bathonian-Kimmeridgian, culminated in the Volgian and waned in the latest Ryazanian - Hauterivian.

Eight low-order tectonostratigraphic sequences are recognised in the Rhaetian-Hauterivian succession, two in the pre-rift megasequence (J1.1-1.2) and six in the 
syn-rift megasequence (J2.1-2.6). They correspond to major changes in tectonic style, basin configuration, drainage pattern, transport directions and depositional environments. Their boundaries are major unconformities or drowning surfaces, and they are not depositional sequences in the sense of Posamentier \& Vail (1988) but rather tectonostratigraphic sequences in the sense of Surlyk (1991b).

Sequence stratigraphic interpretation of the succession illustrates the difficulties in using one, simple, standardised sequence stratigraphic concept or method. Unconformities are well-developed in some parts of the succession and very difficult or impossible to recognise in others. This is also the case with drowning surfaces and marine transgressive or regressive erosion surfaces. The concept of a maximum flooding surface is sedimentologically meaningless but intervals corresponding to maximum flooding can be identified in the lower part of many mudstone-dominated coarsening-upwards units. They are not considered of major importance in most high-resolution outcrop studies but have their main importance in subsurface studies, commonly of lower resolution. Parasequence stacking patterns are well-developed at some levels and completely missing at others.

The Rhaetian-Sinemurian part of the pre-rift megasequence (J1.1) is fluvio-lacustrine and a large number of high-order sequences are recognised, interpreted as having been caused by climatically-controlled lake-level changes, possibly within the Milankovitch frequency band. Long-term lake-level changes may, on the other hand, reflect base-level changes controlled by fluctuations in sea level.

The Pliensbachian - Lower Bajocian shallow marine - paralic part of the pre-rift megasequence (J1.2) shows unconformities and ravinement surfaces, whereas welldeveloped stacking patterns are rarely developed. Sequences are accordingly mainly well-defined, whereas systems tracts are difficult to identify.

The Upper Bajocian - Lower Kimmeridgian part of the syn-rift megasequence (J2.1-2.4) was deposited during a period of major expansion and reorganisation of the basin. Deposition was fully marine with the exception of basal fluvial successions that are developed in a few areas. Stacking patterns are well-developed, but differentiation between unconformities, ravinement and drowning surfaces is difficult. It is thus in many cases an open question as to whether the basic coarseningupwards units are parasequences or simple sequences, or in other words if the top surfaces reflect drowning alone or sea-level fall followed by flooding.
Rapid axial southwards progradation of an extensive shallow marine sandy shelf and shoreface system took place in Late Bajocian time. Deposition was aggradational until the Middle-Late Bathonian when largescale backstepping started, culminating in complete drowning of the sandy system in the Middle Callovian punctuated by a minor progradational episode at the end of the Early Callovian. Backstepping was probably due to increased rates of rifting overprinted by Middle-Late Jurassic eustatic sea-level rise.

The Jameson Land Basin changed from a ramp to a shelf-break margin in the Late Callovian, probably caused by intensified rifting. Two regional progradational events took place in the latest Callovian - Middle Oxfordian marked by the incoming of base-of-slope sands and sandy shelf-margin wedges in the Jameson Land area, by deposition of shallow marine sands on Traill $\varnothing$, and alternating shallow marine sands and thin coastal plain muds in Wollaston Forland.

Drowning of the Middle Oxfordian shallow marine deposits was followed by major regional transgression and deepening, punctuated by a short-lived Late Oxfordian progradational event in Milne Land. By Late Kimmeridgian time, the East Greenland basin was characterised by deposition of mud in fairly deep water under poorly oxygenated conditions. The deepest part of the basin in Jameson Land received sandy gravity flow deposits throughout the Late Oxfordian - Volgian. The sands underwent post-burial liquefaction and were injected into the surrounding mudstones, forming an impressive intrusive sand-body complex. Sand remobilisation and intrusion were probably triggered by riftassociated earthquakes.

The Volgian rift-climax succession is differently developed in the southern and northern parts of the basin complex, reflecting different degrees of block tilting. The southern part centred over Jameson Land behaved as a wide, coherent platform and underwent relatively minor tilting. Maximum Early Kimmeridgian drowning was thus followed by rapid Volgian progradation and regression. Sand deposition took place at the western basin margin during highstands and shifted to the shelf edge located close to the basin axis during late falls and lowstands, where thick clinoform beds were formed. Reworked transgressive drapes were deposited during succeeding sea-level rises. Highstand and lowstand deposits of the same sequence are thus separated by many tens of kilometres.

In the northern part of the basin complex, in the Wollaston Forland area, deep half-grabens were formed during the Middle Volgian rift climax, and thick con- 
glomerates, pebbly sandstones, sandstones and minor mudstones were deposited off the fault scarp from sediment gravity flows. The main motif is a fining-upwards unit, tens of metres thick, thought to reflect major phases of down-faulting and deepening. Sequence stratigraphic key surfaces cannot be identified due to the deep-water nature of the succession but the fining-upwards units may be correlatives of the contemporaneous shallow marine sequences in the Jameson Land area.

Rifting waned in Ryazanian-Hauterivian times and a regional drowning event took place in the latest Ryazanian. In Jameson Land, this is marked by the incoming of massive base-of-slope sands overlying sandy, shallow marine clinoform-bedded shelf-margin wedges. In the Wollaston Forland area, deposition of deep-water conglomerates and pebbly sandstones was succeeded by much finer grained sediments, although coarse clastic deposition still took place. The drainage pattern became more mature and the main sediment entry point was at a transfer zone between right-stepping en echelon border faults. The sediment gravity flows changed from a mainly lateral eastwards to an axial southwards transport direction. The more distal deposits are dominated by calcareous mudstones, and red mudstones drape the submerged block crests.

The Rhaetian-Hauterivian succession of East Greenland thus provides a well-exposed record of Rhaetian - Early Bajocian pre-rift deposition (J1). This was succeeded by Late Bajocian - Hauterivian syn-rift deposition (J2) characterised by different degrees of block faulting and tilting in different parts of the basin.

The Jurassic of East Greenland shows marked similarities to the west Norway shelf, the North Sea and in particular to the Inner Moray Firth. Differences in timing of events may be real or reflect inaccuracies in biostratigraphic correlation due to faunal and floral provincialism, poor resolution of dinocyst stratigraphy in several intervals and poor correlation between ammonite and dinocyst zonations.

\section{Acknowledgements}

I am grateful to the Danish Natural Science Research Council, the Carlsberg Foundation, Norsk Hydro, British Petroleum, Conoco, Statoil, Saga, Norwegian Petroleum Directorate, Amoco and the Danish Ministry of the Environment and Energy for economic support over the years for field work and Ph.D. stipends to a number of students. I thank Peter Alsen for new information on the age of the Rødryggen Member, John $\mathrm{H}$.
Callomon and Gregers Dam for constructive reading of the manuscript, Tony Hallam and Bruce W. Sellwood for useful reviews, Louise A. Hansen and Christian Hagen for drafting, Merete Vesterager for word processing, Ole B. Berthelsen for dark-room work and Jon R. Ineson for careful editing.

\section{References}

Alsen, P. \& Surlyk, F. in press: Maximum Middle Jurassic transgression in East Greenland: evidence from new ammonite finds, Bjørnedal, Traill Ø. In: Stemmerik, L. \& Stouge, S. (eds): The Jurassic of North-East Greenland. Geological Survey of Denmark and Greenland Bulletin.

Alsgaard, P.C., Felt, V.L., Vosgerau, H. \& Surlyk, F. 2003: The Jurassic of Kuhn $\varnothing$, North-East Greenland. In: Ineson, J.R. \& Surlyk, F. (eds): The Jurassic of Denmark and Greenland. Geological Survey of Denmark and Greenland Bulletin 1, 865-892 (this volume).

Anderton, R., Bridges, P.H., Leeder, M.R., Sellwood, B.W. 1979: A dynamic stratigraphy of the British Isles, 301 pp. London: George Allen \& Unwin.

Birkelund, T. \& Callomon, J.H. 1985: The Kimmeridgian ammonite faunas of Milne Land, central East Greenland. Bulletin Grønlands Geologiske Undersøgelse 153, 56 pp.

Birkelund, T. \& Perch-Nielsen, K. 1976: Late Palaeozoic - Mesozoic evolution of central East Greenland. In: Escher, A. \& Watt, W.S. (eds): Geology of Greenland, 304-339. Copenhagen: Geological Survey of Greenland.

Birkelund, T., Callomon, J.H. \& Fürsich, F.T. 1984: The stratigraphy of the Upper Jurassic and Lower Cretaceous sediments of Milne Land, central East Greenland. Bulletin Grønlands Geologiske Undersøgelse 147, 56 pp

Birkenmajer, K. 1976: Middle Jurassic nearshore sediments at Kap Hope, East Greenland. Bulletin of the Geological Society of Denmark 25, 107-116.

Bjerrum, C. 1999: Numerical paleoceanography of a Jurassic narrow meridional seaway: transcontinental currents and global ocean feedbacks, 144 pp. Unpublished Ph.D. thesis, University of Copenhagen, Denmark.

Bojesen-Koefoed, J.A., Petersen, H.I., Surlyk, F. \& Vosgerau, H. 1997: Organic petrography and geochemistry of inertinite-rich mudstones, Jakobsstigen Formation, Upper Jurassic, northeast Greenland: indications of forest fires and variations in relative sea-level. International Journal of Coal Geology 34, 344-370.

Bromley, R.G. \& Asgaard, U. 1972: Notes on Greenland trace fossils. I-III. Rapport Grønlands Geologiske Undersøgelse 49, $30 \mathrm{pp}$.

Bütler, H. 1957: Beobachtungen an der Hauptbruchzone der Küste von Zentral-Ostgrönland. Meddelelser om Grønland 160(1), 79 pp.

Callomon, J.H. 1959: The ammonite zones of the Middle Jurassic beds of East Greenland. Geological Magazine 96, 505-513.

Callomon, J.H. 1961: The Jurassic system in East Greenland. In: 
Raasch, G.O. (ed.): Geology of the Arctic 1, 258-268. Toronto: Toronto University Press.

Callomon, J.H. 1984: A review of the biostratigraphy of the postLower Bajocian Jurassic ammonites of western and northern North America. In: Westermann, G.E.G. (ed.): JurassicCretaceous biochronology and paleogeography of North America. Geological Association of Canada Special Paper 27, 143-174.

Callomon, J.H. 1985: The evolution of the Jurassic ammonite family Cardioceratidae. In: Cope, J.C.W. \& Skelton, P.W. (eds): Evolutionary case histories from the fossil record. Special Papers in Palaeontology 33, 49-90. London: Palaeontological Association.

Callomon, J.H. 1993: The ammonite succession in the Middle Jurassic of East Greenland. Bulletin of the Geological Society of Denmark 40, 83-113.

Callomon, J.H. 1994: Jurassic ammonite biochronology of Greenland and the Arctic. Bulletin of the Geological Society of Denmark 41, 128-137.

Callomon, J.H. 2003: The Middle Jurassic of western and northern Europe: its subdivisions, geochronology and correlations. In: Ineson, J.R. \& Surlyk, F. (eds): The Jurassic of Denmark and Greenland. Geological Survey of Denmark and Greenland Bulletin 1, 61-73 (this volume).

Callomon, J.H. \& Birkelund, T. 1980: The Jurassic transgression and the mid-late Jurassic succession in Milne Land, East Greenland. Geological Magazine 117, 211-226.

Callomon, J.H. \& Birkelund, T. 1982: The ammonite zones of the Boreal Volgian (Upper Jurassic) in East Greenland. In: Embry, A.F. \& Balkwill, H.R. (eds): Arctic geology and geophysics. Canadian Society of Petroleum Geologists Memoir 8, 349-369.

Carr, I.D. 1998: Facies analysis and reservoir characterisation of Jurassic sandstones from Bjørnedal, central East Greenland, 245 pp. Unpublished Ph.D. thesis, University of Reading, UK.

Casey, R. 1973: The ammonite succession at the JurassicCretaceous boundary in eastern England. In: Casey, R. \& Rawson, P.F. (eds): The Boreal Lower Cretaceous. Geological Journal Special Issue 5, 193-266.

Christiansen, F.G. 1994: Seeps and other bitumen showings: a review of the origin, nomenclature and occurrences in Greenland. Open File Series Grønlands Geologiske Undersøgelse 94/7, 21 pp.

Christiansen, F.G., Larsen, H.C., Marcussen, C., Hansen, K., Krabbe, H., Larsen, L.M., Piasecki, S., Stemmerik, L. \& Watt, W.S. 1992a: Uplift study of the Jameson Land Basin, East Greenland. Norsk Geologisk Tidsskrift 72, 291-294.

Christiansen, F.G., Dam, G., Piasecki, S. \& Stemmerik, L. 1992b: A review of Upper Palaeozoic and Mesozoic source rocks from onshore East Greenland. In: Spencer, A.M. (ed.): Generation, accumulation and production of Europe's hydrocarbons II. The European Association of Petroleum Geoscientists Special Publication 2, 151-161.

Clemmensen, L.B. 1976: Tidally influenced deltaic sequences from the Kap Stewart Formation (Rhaetic-Liassic), Scoresby Land, East Greenland. Bulletin of the Geological Society of Denmark 25, 1-13.

Clemmensen, L.B. 1980a: Triassic rift sedimentation and palaeo- geography of central East Greenland. Bulletin Grønlands Geologiske Undersøgelse 136, 72 pp.

Clemmensen, L.B. 1980b: Triassic lithostratigraphy of East Greenland between Scoresby Sund and Kejser Franz Josephs Fjord. Bulletin Grønlands Geologiske Undersøgelse 139, 56 pp.

Clemmensen, L.B. \& Surlyk, F. 1976: Upper Jurassic coal-bearing shoreline deposits, Hochstetter Forland, East Greenland. Sedimentary Geology 15, 193-211.

Dalland, A. 1981: Mesozoic sedimentary succession at Andøy, northern Norway, and relation to structural development of the North Atlantic area. In: Kerr, J.W. \& Fergusson, A.J. (eds): Geology of the North Atlantic Borderlands. Canadian Society of Petroleum Geologists Memoir 7, 563-584.

Dam, G. 1990a: Taxonomy of trace fossils from the shallow marine Lower Jurassic Neill Klinter Formation, East Greenland. Bulletin of the Geological Society of Denmark 38, 119-144.

Dam, G. 1990b: Palaeoenvironmental significance of trace fossils from the shallow marine Lower Jurassic Neill Klinter Formation, East Greenland. Palaeogeography, Palaeoclimatology, Palaeoecology 79, 221-248.

Dam, G. 1991: A sedimentological analysis of the continental and shallow marine Upper Triassic to Lower Jurassic succession in Jameson Land, East Greenland, 1-6, 243 pp. Unpublished Ph.D. thesis, University of Copenhagen, Denmark.

Dam, G. \& Christiansen, F.G. 1990: Organic geochemistry and source potential of the lacustrine shales of the Upper Triassic - Lower Jurassic Kap Stewart Formation. Marine and Petroleum Geology 7, 428-443.

Dam, G. \& Surlyk, F. 1992: Forced regressions in a large waveand storm-dominated anoxic lake, Rhaetian-Sinemurian Kap Stewart Formation, East Greenland. Geology 20, 748-751.

Dam, G. \& Surlyk, F. 1993: Cyclic sedimentation in a large waveand storm-dominated anoxic lake; Kap Stewart Formation (Rhaetian-Sinemurian), Jameson Land, East Greenland. In: Posamentier et al. (eds): Sequence stratigraphy and facies associations. International Association of Sedimentologists Special Publication 18, 419-448.

Dam, G. \& Surlyk, F. 1995: Sequence stratigraphic correlation of Lower Jurassic shallow marine and paralic successions across the Greenland-Norway seaway. In: Steel, R.J. et al. (eds): Sequence stratigraphy on the Northwest European margin. Norwegian Petroleum Society (NPF) Special Publication 5 483-499.

Dam, G. \& Surlyk, F. 1998: Stratigraphy of the Neill Klinter Group; a Lower - lower Middle Jurassic tidal embayment succession, Jameson Land, East Greenland. Geology of Greenland Survey Bulletin 175, 80 pp.

Dam, G., Surlyk, F., Mathiesen, A. \&. Christiansen, F.G. 1995: Exploration significance of lacustrine forced regressions of the Rhaetian-Sinemurian Kap Stewart Formation, Jameson Land, East Greenland. In: Steel, R.J. et al. (eds): Sequence stratigraphy on the Northwest European margin. Norwegian Petroleum Society (NPF) Special Publication 5, 511-527.

Damholt, T. 1996: En sedimentologisk analyse af Allt na Cuile Sandstenen, Øvre Jura, Skotland, 106 pp. [A sedimentological analysis of the Allt na Cuile Sandstone, Upper Jurassic, Scotland]. Unpublished cand. scient. thesis, Københavns 
Universitet, Danmark.

Donovan, D.T. 1957: The Jurassic and Cretaceous systems in East Greenland. Meddelelser om Grønland 154(4), 214 pp.

Donovan, D.T. \& Surlyk, F. 2003: Lower Jurassic (Pliensbachian) ammonites from Bornholm, Baltic Sea, Denmark. In: Ineson, J.R. \& Surlyk, F. (eds): The Jurassic of Denmark and Greenland. Geological Survey of Denmark and Greenland Bulletin 1, 555-583 (this volume).

Doré, A.G. 1992: Synoptic palaeogeography of the Northeast Atlantic Seaway: Late Permian to Cretaceous. In: Parnell, J. (ed.): Basins on the Atlantic seaboard: petroleum geology, sedimentology and basin evolution. Geological Society Special Publication (London) 62, 421-446.

Doré, A.G., Lundin, E.R., Jensen, L.N., Birkeland, Ø., Eliassen, P.E. \& Fichler, C. 1999: Principal tectonic events in the evolution of the northwest European Atlantic margin. In: Fleet, A.J. \& Boldy, S.A.R. (eds): Petroleum geology of Northwest Europe: proceedings of the 5 th conference, 40-61. London: Geological Society.

Engkilde, M. 1994: The Middle Jurassic Vardekløft Formation, East Greenland: depositional environments and sequence stratigraphy of shallow marine sandstones deposited in a lowgradient epeiric seaway, 207 pp. Unpublished Ph.D. thesis, University of Copenhagen, Denmark.

Engkilde, M. \& Surlyk, F. 1993: The Middle Jurassic Vardekløft Formation of East Greenland - analogue for reservoir units of the Norwegian shelf and the Northern North Sea. In: Parker, J.R. (ed.): Petroleum geology of Northwest Europe: proceedings of the 4th conference. 533-542. London: Geological Society.

Engkilde, M. \& Surlyk, F. 2003: Shallow marine syn-rift sedimentation: Middle Jurassic Pelion Formation, Jameson Land, East Greenland. In: Ineson, J.R. \& Surlyk, F. (eds): The Jurassic of Denmark and Greenland. Geological Survey of Denmark and Greenland Bulletin 1, 813-863 (this volume).

Fürsich, F.T. 1982a: Upper Jurassic bivalves from Milne Land, East Greenland. Bulletin Grønlands Geologiske Undersøgelse 144, $126 \mathrm{pp}$.

Fürsich, F.T. 1982b: Rhythmic bedding and shell bed formation in the Upper Jurassic of East Greenland. In: Einsele, G. \& Seilacher, A. (eds): Cyclic and event stratification, 208-222. Berlin: Springer Verlag.

Fürsich, F.T. \& Heinberg, C. 1983: Sedimentology, biostratinomy, and palaeoecology of an Upper Jurassic offshore sand bar complex. Bulletin of the Geological Society of Denmark 32, 67-95.

Hallam. A. 1988: A reevaluation of Jurassic eustasy in the light of new data and the revised EXXON curve. In: Wilgus, C.K. et al. (eds): Sea-level changes - an integrated approach. Society of Economic Paleontologists and Mineralogists Special Publication 42, 261-273.

Hallam, A. 1997: Estimates of the amount and rate of sea-level change across the Rhaetian-Hettangian and PliensbachianToarcian boundaries (latest Jurassic to early Jurassic). Journal of the Geological Society (London) 153, 773-779.

Haller, J. 1971: Geology of the East Greenland Caledonides, 413 pp. London: Interscience Publishers.
Hansen, C.F. 1999: Sedimentology, sequence stratigraphy and geochemistry of the Sortehat Formation, Jameson Land, East Greenland 1-3, 167 pp. Unpublished Ph.D. thesis, University of Copenhagen, Denmark.

Hansen, K. 2000: Tracking thermal history in East Greenland: an overview. Global and Planetary Change 24, 303-309.

Harris, T. 1937: The fossil flora of Scoresby Sound East Greenland. 5. Stratigraphic relations of the plant beds. Meddelelser om Grønland 112(1), 114 pp.

Haq, B.U., Hardenbol, J. \& Vail, P.R. 1988: Mesozoic and Cenozoic chronostratigraphy and cycles of sea-level change. In: Wilgus, C.K. et al. (eds): Sea-level changes - an integrated approach. Society of Economic Paleontologists and Mineralogists Special Publication 42, 71-108.

Heinberg, C. 1970: Some Jurassic trace fossils from Jameson Land (East Greenland). In: Crimes, T.P. \& Harper, J.C. (eds): Trace fossils. Geological Journal Special Issue 3, 227-234.

Heinberg, C. 1973: The internal structure of the trace fossils Gyrochorte and Curvolithus. Lethaia 6, 227-239.

Heinberg, C. 1974: A dynamic model for a meniscus filled tunnel (Ancorichnus n. ichnogen.) from the Jurassic Pecten Sandstone of Milne Land, East Greenland. Rapport Grønlands Geologiske Unders $\varnothing$ gelse 62, 20 pp.

Heinberg, C. \& Birkelund, T. 1984: Trace fossil assemblages and basin evolution of the Vardekløft Formation (Middle Jurassic, Central East Greenland). Journal of Paleontology 58, 362-397.

Herngreen, G.F.W., Kouwe, W.F.P. \& Wong, T.E. 2003: The Jurassic of the Netherlands. In: Ineson, J.R. \& Surlyk, F. (eds): The Jurassic of Denmark and Greenland. Geological Survey of Denmark and Greenland Bulletin 1, 217-229 (this volume).

Hesselbo, S.P., Robinson, S.A., Surlyk, F. \& Piasecki, S. 2002: Terrestrial and marine extinction at the Triassic-Jurassic boundary synchronized with major carbon-cycle perturbation: a link to initiation of massive volcanism? Geology 30, 251-254.

Hunt, D. \& Tucker, M.E. 1992: Stranded parasequences and the forced regressive wedge systems tract: deposition during baselevel fall. Sedimentary Geology $\mathbf{8 1}, 1-9$.

Hunt, D. \& Tucker, M.E. 1995: Stranded parasequences and the forced regressive wedge systems tract: deposition during baselevel fall - reply. Sedimentary Geology 95, 147-160.

Hurst, A. 1993: Bathonian to Oxfordian strata of the Brora area. In: Trewin, N.H. \& Hurst, A. (eds): Excursion guide to the geology of East Sutherland and Caithness, 48-74. Edinburgh: Scottish Academic Press for the Geological Society of Aberdeen.

Johnson, C. \& Gallagher, K. 2000: A preliminary Mesozoic and Cenozoic denudation history of the North East Greenland onshore margin. Global and Planetary Change 24, 261-274.

Koppelhus, E.B. \& Dam, G. 2003: Palynostratigraphy and palaeoenvironments of the Rævekløft, Gule Horn and Ostreaelv Formations (Lower-Middle Jurassic), Neill Klinter Group, Jameson Land, East Greenland. In: Ineson, J.R. \& Surlyk, F. (eds): The Jurassic of Denmark and Greenland. Geological Survey of Denmark and Greenland Bulletin 1, 723-775 (this volume)

Koppelhus, E.B. \& Hansen, C.F. 2003: Palynostratigraphy and palaeoenvironment of the Middle Jurassic Sortehat Formation (Neill Klinter Group), Jameson Land, East Greenland. In: 
Ineson, J.R. \& Surlyk, F. (eds): The Jurassic of Denmark and Greenland. Geological Survey of Denmark and Greenland Bulletin 1, 777-811 (this volume).

Krabbe, H., Christiansen, F.G., Dam, G., Piasecki, S. \& Stemmerik, L. 1994: Organic geochemistry of the Lower Jurassic Sortehat Formation, Jameson Land, East Greenland. Rapport Grønlands Geologiske Undersøgelse 164, 5-18.

Larsen, H.C. 1984: Geology of the East Greenland shelf. In: Spencer, A.M. et al. (eds): Petroleum geology of the North European margin, 329-339. London: Graham \& Trotman for the Norwegian Petroleum Society (NPF).

Larsen, H.C. \& Marcussen, C. 1992: Sill-intrusion, flood basalt emplacement and deep crustal structure of the Scoresby Sund region, East Greenland. In: Storey, B.C., Alabaster, T. \& Pankhurst, R.J. (eds): Magmatism and the causes of continental break-up. Geological Society Special Publication (London) 68, 365-386.

Larsen, M. 1995: Facies architecture and sequence stratigraphy of basement-onlapping shallow marine sandstones of the Charcot Bugt Formation, Middle Jurassic, East Greenland 1, 121 pp. Unpublished Ph.D. thesis, University of Copenhagen, Denmark.

Larsen, M. \& Surlyk, F. 2003: Shelf-edge delta and slope deposition in the Upper Callovian - Middle Oxfordian Olympen Formation, East Greenland. In: Ineson, J.R. \& Surlyk, F. (eds): The Jurassic of Denmark and Greenland. Geological Survey of Denmark and Greenland Bulletin 1, 931-948 (this volume).

Larsen, M., Piasecki, S. \& Surlyk, F. 2003: Stratigraphy and sedimentology of a basement-onlapping shallow marine sandstone succession, the Charcot Bugt Formation, Middle-Upper Jurassic, East Greenland. In: Ineson, J.R. \& Surlyk, F. (eds): The Jurassic of Denmark and Greenland. Geological Survey of Denmark and Greenland Bulletin 1, 893-930 (this volume).

MacDonald, A.C. \& Trewin, N.H. 1993: The Upper Jurassic of the Helmsdale area. In: Trewin, N.H. \& Hurst, A. (eds): Excursion guide to the geology of East Sutherland and Caithness, 75-114. Edinburgh: Scottish Academic Press for the Geological Society of Aberdeen.

Marcussen, C., Christiansen, F.G., Larsen, P.-H., Olsen, H., Piasecki, S., Stemmerik, L., Bojesen-Koefoed, J., Jepsen, H.F. \& NøhrHansen, H. 1987: Studies of the onshore oil potential in East Greenland 1986-87: field work from $72^{\circ}$ to $74^{\circ} \mathrm{N}$. Rapport Grønlands Geologiske Undersøgelse 135, 72-81.

Mathiesen, A., Bidstrup, T. \& Christiansen, F.G. 2000: Denudation and uplift history of the Jameson Land Basin, East Greenland - constrained from maturity and apatite fission track data. Global and Planetary Change 24, 275-301.

Maync, W. 1947: Stratigraphie der Jurabildungen Ostgrönlands zwischen Hochstetterbugten $\left(75^{\circ} \mathrm{N}\right)$ und dem Kejser Franz Joseph Fjord $\left(73^{\circ} \mathrm{N}\right)$. Meddelelser om Grønland 132(2), 223 pp.

Maync, W. 1949: The Cretaceous beds between Kuhn Island and Cape Franklin (Gauss Peninsula), northern East Greenland. Meddelelser om Grønland 133(3), 291 pp.

McElwain, J.C., Beerling, D.J. \& Woodward, F.I. 1999: Fossil plants and global warming at the Triassic-Jurassic boundary. Science 285, 1396-1390.
Miall, A.D. 1990: Principles of sedimentary basin analysis, 668 pp. New York: Springer Verlag.

Milner, P.S. \& Piasecki, S. 1996: Boreal Middle Jurassic dinoflagellate cyst stratigraphy of Jameson Land, East Greenland. In: Piasecki, S. et al. (eds): Formation of source and reservoir rocks in a sequence stratigraphic framework, Jameson Land, East Greenland. Danmarks og Grønlands Geologiske Undersøgelse Rapport 1996/30(II), 45 pp.

Olsen, P.E., Kent, D.V., Cornet, B., Witte, W.K. \& Schlische, R.W. 1996: High-resolution stratigraphy of the Newark rift basin (early Mesozoic, eastern North America). Geological Society of America Bulletin 108, 40-77.

Partington, M.A., Copestake, P., Mitchener, B.C. \& Underhill, J.R. 1993a: Biostratigraphic calibration of genetic stratigraphic sequences in the Jurassic - lowermost Cretaceous (Hettangian to Ryazanian) of the North Sea and adjacent areas. In: Parker, J.R. (ed.): Petroleum geology of Northwest Europe: proceedings of the 4th conference, 371-386. London: Geological Society.

Partington, M.A., Mitchener, B.C., Milton, N.J. \& Fraser, A.J. 1993b: Genetic sequence stratigraphy for the North Sea Late Jurassic and Early Cretaceous: distribution and prediction of Kimmeridgian - Late Ryazanian reservoirs in the North Sea and adjacent areas. In: Parker, J.R. (ed.): Petroleum geology of Northwest Europe: proceedings of the 4th conference, 347-370. London: Geological Society.

Pedersen, K.R. \& Lund, J.J. 1980: Palynology of the plant-bearing Rhaetian to Hettangian Kap Stewart Formation, Scoresby Sund, East Greenland. Review of Palaeobotany and Palynology 31, 1-69.

Petersen, H.I., Bojesen-Koefoed, J.A., Nytoft, H.P., Surlyk, F., Therkelsen, J. \& Vosgerau, H. 1998: Relative sea-level changes recorded by paralic liptinite-enriched coal facies cycles, Middle Jurassic Muslingebjerg Formation, Hochstetter Forland, Northeast Greenland. International Journal of Coal Geology 36, 1-30.

Piasecki, S. 1981: Middle to Late Jurassic dinoflagellate cyst stratigraphy from Milne Land and Jameson Land (East Greenland) correlated with ammonite stratigraphy, 167 pp. Unpublished Ph.D. thesis, University of Copenhagen, Denmark.

Piasecki, S. 1996: Boreal dinoflagellate cyst stratigraphy of Middle to Upper Jurassic sediments of Milne Land, East Greenland. In: Piasecki, S. et al. (eds): Formation of source and reservoir rocks in a sequence stratigraphic framework, Jameson Land, East Greenland. Danmarks og Grønlands Geologiske Undersøgelse Rapport 1996/30(I), 100 pp.

Piasecki, S., Callomon, J.H. \& Stemmerik, L. in press: Jurassic dinoflagellate cyst stratigraphy of Store Koldewey, North-East Greenland. In: Stemmerik, L. \& Stouge, S. (eds): The Jurassic of North-East Greenland. Geological Survey of Denmark and Greenland Bulletin.

Pickering, K.T. 1984: The Upper Jurassic 'Boulder Beds' and related deposits: a fault-controlled submarine slope, NE Scotland. Journal of the Geological Society (London) 141 , 357-374.

Plint, A.G. \& Nummedal, D. 2000: The falling stage systems tract: recognition and importance in sequence stratigraphic analysis. In: Hunt, D. \& Gawthorpe, R.L. (eds): Sedimentary response 
to forced regressions. Geological Society Special Publication (London) 172, 1-17.

Pomar, L. \& Tropeano, M. 2001: The Calcarenite di Gravina Formation in Matera (southern Italy): new insights for coarsegrained, large-scale, cross-bedded bodies encased in offshore deposits. American Association of Petroleum Geologists Bulletin 85, 661-689.

Posamentier, H.W. \& Allen, G.P. 1999: Siliciclastic sequence stratigraphy - concepts and applications. SEPM (Society for Sedimentary Geology) Concepts in Sedimentology and Paleontology 7, $210 \mathrm{pp}$

Posamentier, H.W. \& Vail, P.F. 1988: Eustatic controls on clastic deposition II - sequence and systems tract models. In: Wilgus, C.K. et al. (eds): Sea-level changes - an integrated approach. Society of Economic Paleontologists and Mineralogists Special Publication 42, 125-154.

Price, S.R. \& Whitham, A.G. 1997: Exhumed hydrocarbon traps in East Greenland: analogs for the Lower-Middle Jurassic play of Northwest Europe. American Association of Petroleum Geologists Bulletin 81, 196-221.

Rattey, R.P. \& Hayward, A.B. 1993: Sequence stratigraphy of a failed rift system: the Middle Jurassic to Early Cretaceous basin evolution of the Central and Northern North Sea. In: Parker, J.R. (ed.): Petroleum geology of Northwest Europe: proceedings of the 4th conference, 215-249. London: Geological Society.

Sellwood, B.W. 1972: Regional environmental changes across a Lower Jurassic stage-boundary in Britain. Palaeontology 15, 125-157.

Sellwood, B.W., Valdes, P.J. \& Price, G.D. 2000: Geological evaluation of multiple general circulation model simulations of Late Jurassic palaeoclimate. Palaeogeography, Palaeoclimatology, Palaeoecology 156, 147-160.

Smith, A.G., Smith, D.G. \& Funnell, B.M. 1994: Atlas of Mesozoic and Cenozoic coastlines, 99 pp. Cambridge: Cambridge University Press.

Sneider, J.S., deClarens, P. \& Vail, P.R. 1995: Sequence stratigraphy of the Middle to Upper Jurassic, Viking Graben, North Sea. In: Steel, R.J. et al. (eds): Sequence stratigraphy on the Northwest European margin. Norwegian Petroleum Society (NPF) Special Publication 5, 167-197.

Stemmerik, L. \& Piasecki, S. 1990: Post-Caledonian sediments in North-East Greenland between $76^{\circ}$ and $78^{\circ} 30^{\prime} \mathrm{N}$. Rapport Grønlands Geologiske Undersøgelse 148, 123-126.

Stephen, K.J. \& Davies, R.J. 1998: Documentation of Jurassic sedimentary cycles from the Moray Firth basin, United Kingdom North Sea. In: de Graciansky, P.-C. et al. (eds): Mesozoic and Cenozoic sequence stratigraphy of European basins. SEPM (Society for Sedimentary Geology) Special Publication 60, 481-506.

Stephen, K.J., Underhill, J.R., Partington, M.A. \& Hedley, R.J. 1993: The genetic sequence stratigraphy of the Hettangian to Oxfordian succession, Inner Moray Firth. In: Parker, J.R. (ed.): Petroleum geology of Northwest Europe: proceedings of the 4th conference, 485-505. London: Geological Society.

Stewart, D.J., Schwander, M. \& Bolle, L. 1995: Jurassic depositional systems of the Horda Platform, Norwegian North Sea: practical consequences of applying sequence stratigraphic models. In: Steel, R.J. et al. (eds): Sequence stratigraphy on the Northwest European margin. Norwegian Petroleum Society (NPF) Special Publication 5, 291-323.

Surlyk, F. 1977a: Mesozoic faulting in East Greenland. In: Frost, R.T.C. \& Dikkers, A.J. (eds): Fault tectonics in NW Europe. Geologie en Mijnbouw 56, 311-327.

Surlyk, F. 1977b: Stratigraphy, tectonics and palaeogeography of the Jurassic sediments of the areas north of Kong Oscars Fjord, East Greenland. Bulletin Grønlands Geologiske Undersøgelse 123, $56 \mathrm{pp}$

Surlyk, F. 1978a: Jurassic basin evolution of East Greenland. Nature 274, 130-133.

Surlyk, F. 1978b: Submarine fan sedimentation along fault scarps on tilted fault blocks (Jurassic-Cretaceous boundary, East Greenland). Bulletin Grønlands Geologiske Undersøgelse 128, 108 pp.

Surlyk, F. 1984: Fan-delta to submarine fan conglomerates of the Volgian-Valanginian Wollaston Forland Group, East Greenland. In: Koster, E.H. \& Steel, R.J. (eds): Sedimentology of gravels and conglomerates. Canadian Society of Petroleum Geologists Memoir 10, 359-382.

Surlyk, F. 1987: Slope and deep shelf gully sandstones, Upper Jurassic, East Greenland. American Association of Petroleum Geologists Bulletin 71, 464-475.

Surlyk, F. 1989: Mid-Mesozoic syn-rift turbidite systems: controls and predictions. In: Collinson, J.D. (ed.): Correlation in hydrocarbon exploration, 231-241. London: Graham \& Trotman for the Norwegian Petroleum Society (NPF).

Surlyk, F. 1990a: Timing, style and sedimentary evolution of Late Palaeozoic - Mesozoic extensional basins of East Greenland. In: Hardman, R.F.P. \& Brooks, J. (eds): Tectonic events responsible for Britain's oil and gas reserves. Geological Society Special Publication (London) 55, 107-125.

Surlyk, F. 1990b: A Jurassic sea-level curve for East Greenland. Palaeogeography, Palaeoclimatology, Palaeoecology 78, 71-85.

Surlyk, F. 1991a: Sequence stratigraphy of the Jurassic - lowermost Cretaceous of East Greenland. American Association of Petroleum Geologists Bulletin 75, 1468-1488.

Surlyk, F. 1991b: Tectonostratigraphy of North Greenland. In: Peel, J.S. \& Sønderholm, M. (eds): Sedimentary basins of North Greenland. Bulletin Grønlands Geologiske Undersøgelse 160, $25-47$.

Surlyk, F. \& Clemmensen, L.B. 1983: Rift propagation and eustacy as controlling factors during Jurassic inshore and shelf sedimentation in northern East Greenland. Sedimentary Geology 34, 119-143.

Surlyk, F. \& Noe-Nygaard, N. 1991: Sand bank and dune facies architecture of a wide intracratonic seaway: Late Jurassic - Early Cretaceous Raukelv Formation, Jameson Land, East Greenland. In: Miall, A.D. \& Tyler, N. (eds): The three-dimensional facies architecture of terrigenous clastic sediments and its implication for hydrocarbon discovery and recovery. SEPM (Society for Sedimentary Geology) Concepts in Sedimentology and Paleontology 3, 261-276.

Surlyk, F. \& Noe-Nygaard, N. 1995: High-angle clinoform beds a recurrent architectural element in Jurassic shallow marine 
deposits of East Greenland. Sedimentary responses to forced regression: recognition, interpretation and reservoir potential. Geological Society, London, 7-9 September 1995. Programme with abstracts, 64-65.

Surlyk, F. \& Noe-Nygaard, N. 1998: Massive intrusive sandstones, Upper Jurassic Hareelv Formation, East Greenland: a new class of deep-water sandstones. Geoscience '98, Keele University, 14-18 April, 1998. Abstracts, 7 only.

Surlyk, F. \& Noe-Nygaard, N. 2000a: Jurassic sequence stratigraphy of East Greenland. In: Hall, R.L. \& Smith, P.L. (eds): Advances in Jurassic research 2000. Proceedings of the 5th International Symposium on the Jurassic System. GeoResearch Forum 6, 357-366.

Surlyk, F. \& Noe-Nygaard, N. 2000b: Shelf-edge deltas, slope gullies and base-of-slope massive sands, Upper Jurassic, east Greenland: field analog for a complex type of reservoir. 2000 AAPG Annual Convention, New Orleans, Louisiana, 16-19 April 2000. Official Program 9, A144 only.

Surlyk, F. \& Noe-Nygaard, N. 2001a: Cretaceous faulting and associated coarse-grained marine gravity flow sedimentation, Traill $\varnothing$, East Greenland. In: Martinsen, O.J. \& Dreyer, T. (eds): Sedimentary environments offshore Norway - Palaeozoic to Recent. Norwegian Petroleum Society (NPF) Special Publication 10, 293-319.

Surlyk, F. \& Noe-Nygaard, N. 2001b: Sand remobilisation and intrusion in the Upper Jurassic Hareelv Formation of East Greenland. In: Surlyk, F. \& Håkansson, E. (eds): Oscar volume. Bulletin of the Geological Society of Denmark 48, 169-188.

Surlyk, F., Callomon, J.H., Bromley, R.G. \& Birkelund, T. 1973: Stratigraphy of the Jurassic - Lower Cretaceous sediments of Jameson Land and Scoresby Land, East Greenland. Bulletin Grønlands Geologiske Undersøgelse 105, 76 pp.

Surlyk, F., Clemmensen, L.B. \& Larsen, H.C. 1981: Post-Paleozoic evolution of the East Greenland continental margin. In: Kerr, J.W. \& Fergusson, A.J. (eds): Geology of the North Atlantic Borderlands. Canadian Society of Petroleum Geologists Memoir 7, 611-645.

Surlyk, F., Noe-Nygaard, N. \& Dam, G. 1993: High and low resolution sequence stratigraphy in lithological prediction - examples from the Mesozoic around the northern North Atlantic. In: Parker, J.R. (ed.): Petroleum geology of Northwest Europe: proceedings of the 4th conference, 199-214. London: Geological Society.

Surlyk, F., Arndorff, L., Hamann, N.-E., Hamberg, L., Johannessen, P.N., Koppelhus, E.B., Nielsen, L.H., Noe-Nygaard, N., Pedersen, G.K. \& Petersen, H.I. 1995: High-resolution sequence stratigraphy of a Hettangian-Sinemurian paralic succession, Bornholm, Denmark. Sedimentology 42, 323-354.

Sykes, R.M. 1974a: Sedimentological studies in southern Jameson Land, East Greenland. I. Fluviatile sequences in the Kap Stewart Formation (Rhaetic-Hettangian). Bulletin of the Geological Society of Denmark 23, 203-212.

Sykes, R.M. 1974b: Sedimentological studies in southern Jameson Land, East Greenland. II. Offshore-estuarine regressive sequences in the Neill Klinter Formation (PliensbachianToarcian). Bulletin of the Geological Society of Denmark 23, 213-224.
Sykes, R.M. 1975: The stratigraphy of the Callovian and Oxfordian stages (Middle-Upper Jurassic) in northern Scotland. Scottish Journal of Geology 11, 51-78.

Sykes, R.M. \& Surlyk, F. 1976: A revised ammonite zonation of the Boreal Oxfordian and its application in north-east Greenland. Lethaia 9, 421-436.

Sykes, R.M. \& Callomon, J.H. 1979: The Amoeboceras zonation of the Boreal Upper Oxfordian. Palaeontology 22, 839-903.

Taylor, S.P., Sellwood, B.W., Gallois, R.W. \& Chambers, M.H. 2001: A sequence stratigraphy of the Kimmeridgian and Bolonian stages (late Jurassic): Wessex-Weald Basin, southern England. Journal of the Geological Society (London) 158, 179-192.

Theriault, P. \& Steel, R.J. 1995: Syn-rift sedimentation in the Upper Jurassic (Helmsdale Boulder Beds) of the Inner Moray Firth. In: Steel, R.J. et al. (eds): Sequence stratigraphy on the Northwest European margin. Norwegian Petroleum Society (NPF) Special Publication 5, 365-387.

Therkelsen, J. 2000: Petrographic and diagenetic studies on Triassic and Jurassic sandstones in the Traill $\varnothing$ region, East Greenland. Unpublished Ph.D. thesis, University of Copenhagen, Denmark.

Therkelsen, J. \& Surlyk, F. in press: The fluviatile Bristol Elv Formation, a new Middle Jurassic lithostratigraphical unit from Traill $\varnothing$, North-East Greenland. In: Stemmerik, L. \& Stouge, S. (eds): The Jurassic of North-East Greenland. Geological Survey of Denmark and Greenland Bulletin.

Trewin, N.H. \& Hurst, A. (eds) 1993: Excursion guide to the geology of East Sutherland and Caithness, 183 pp. Edinburgh: Scottish Academic Press for the Geological Society of Aberdeen.

Underhill, J.R. 1991: Controls on Late Jurassic seismic sequences, Inner Moray Firth, UK North Sea: a critical test of a key segment of Exxon's original global cycle chart. Basin Research 3, 79-98.

Underhill, J. \& Partington, M.A. 1994: Use of genetic sequence stratigraphy in defining and determining a regional tectonic control on the 'Mid-Cimmerian Unconformity' - implications for North Sea Basin development and the global sea-level chart. In: Weimer, P. \& Posamentier, H. (eds): Siliciclastic sequence stratigraphy. American Association of Petroleum Geologists Memoir 58, 449-484.

Vischer, A. 1943: Die postdevonische Tektonik von Ostgrönland zwischen $74^{\circ}$ und $75^{\circ} \mathrm{N}$. Br., Kuhn $\varnothing$, Wollaston Forland, Clavering $\varnothing$ und angrenzende Gebiete. Meddelelser om Grønland 133(1), 195 pp.

Vosgerau, H. 1997: Depositional environments and sequence stratigraphy of a Middle-Upper Jurassic early syn-rift succession deposited in a low-gradient epeiric seaway, the Wollaston Forland Basin, Northeast Greenland, 1-3, 110 pp. Unpublished Ph.D. thesis, University of Copenhagen, Denmark.

Vosgerau, H., Bojesen-Koefoed, J.A., Petersen, H.I. \& Surlyk, F. 2000: Forest fires, climate, and sea-level changes in a coastal plain - shallow marine succession (Early-Middle Oxfordian Jakobsstigen Formation, North-East Greenland). Journal of Sedimentary Research 70, 408-418.

Vosgerau, H., Larsen, M., Piasecki, S. \& Therkelsen, J. in press a: A new Middle-Upper Jurassic succession of Hold with Hope, North-East Greenland. In: Stemmerik, L. \& Stouge S. (eds): The 
Jurassic of North-East Greenland. Geological Survey of Denmark and Greenland Bulletin.

Vosgerau, H., Alsen, P., Carr, I.D., Therkelsen, J., Stemmerik, L. \& Surlyk, F. in press b: Jurassic syn-rift sedimentation on a seawards tilted fault block, Traill $\varnothing$, North-East Greenland. In: Stemmerik, L. \& Stouge, S. (eds): The Jurassic of North-East Greenland. Geological Survey of Denmark and Greenland Bulletin.

Wignall, P.B. 1991: Test of the concepts of sequence stratigraphy in the Kimmeridgian (Late Jurassic) of England and northern France. Marine and Petroleum Geology 8, 430-441.
Wignall, P.B. \& Pickering, K.T. 1993: Palaeoecology and sedimentology across a Jurassic fault scarp, NE Scotland. Journal of the Geological Society (London) 150, 323-340.

Zeiss, A. 2003: The Upper Jurassic of Europe: its subdivision and correlation. In: Ineson, J.R. \& Surlyk, F. (eds): The Jurassic of Denmark and Greenland. Geological Survey of Denmark and Greenland Bulletin 1, 75-114 (this volume).

Ziegler, P. 1988: Evolution of the Arctic - North Atlantic and the western Tethys. American Association of Petroleum Geologists Memoir 43, 198 pp.

Manuscript received 19 June 2001; revision accepted 27 September 2001. 


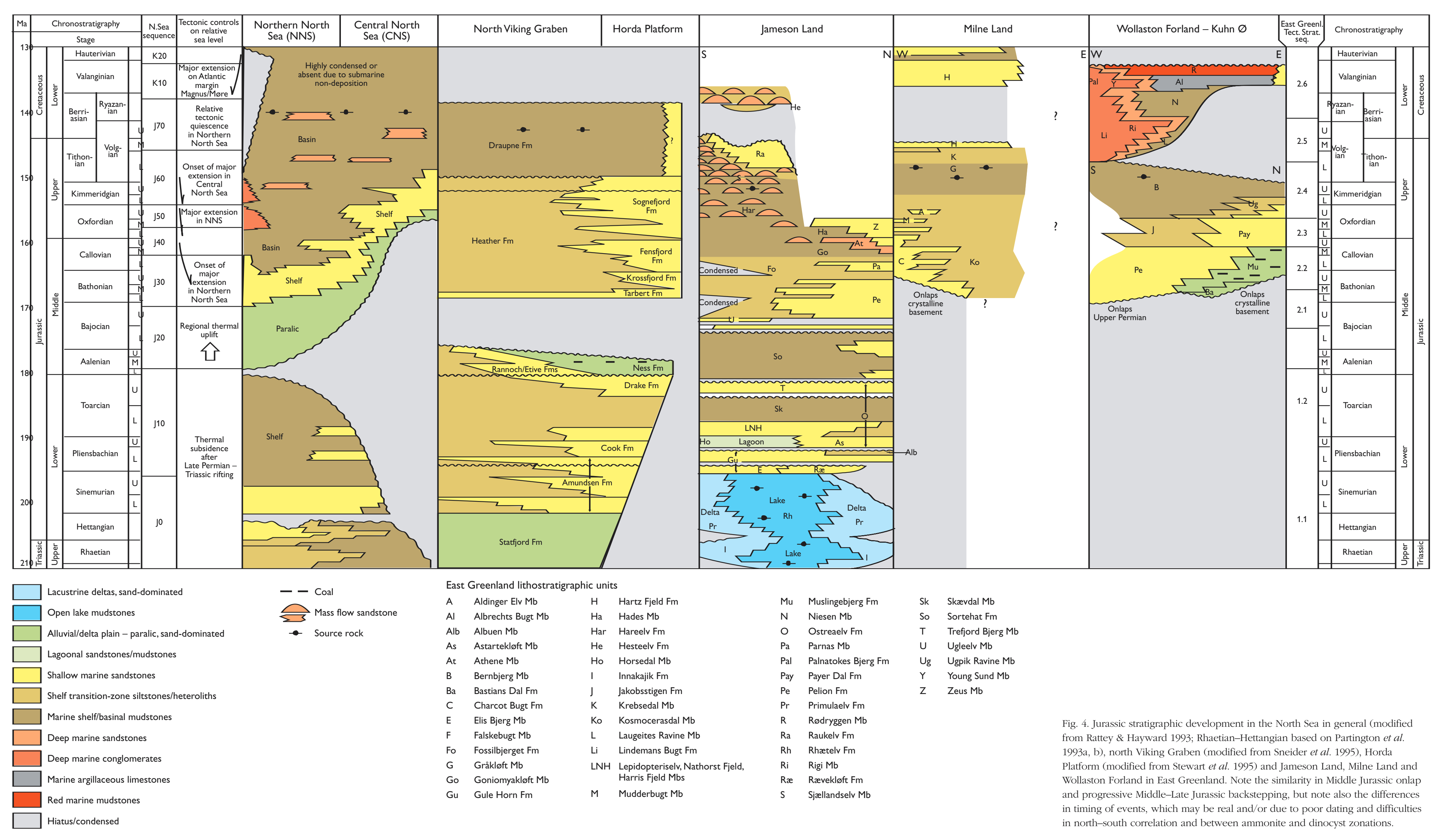

